\title{
Structure, Bioactivity and Synthesis of Natural Products with Hexahydropyrrolo[2,3-b]indole
}

\begin{abstract}
Pau Ruiz-Sanchis, ${ }^{a}$ Svetlana A. Savina, ${ }^{a, b}$ Fernando Albericio, ${ }^{a, b, c}$ and Mercedes Álvarez ${ }^{a, b, d}$
a Institute for Research in Biomedicine, Barcelona Science Park, Baldiri i Reixac 10, 08028 Barcelona, Spain; ${ }^{b}$ CIBER-BBN, Networking Centre on Bioengineering, Biomaterials and Nanomedicine, Barcelona Science Park, Baldiri i Reixac 10, 08028 Barcelona, Spain; ${ }^{c}$ Department of Organic Chemistry, University of Barcelona, 08028 Barcelona, Spain; ${ }^{d}$ Laboratory of Organic Chemistry, Faculty of Pharmacy, University of Barcelona, 08028 Barcelona, Spain
\end{abstract}

\begin{abstract}
Research on natural products containing hexahydropyrrolo[2,3-b]indole (HPI) has dramatically increased during the past few years. Newly discovered natural products with complex structures and important biological activities have recently been isolated and synthesized. This review summarizes the structures, biological activities, and synthetic routes for natural compounds containing HPI, emphasizing the different strategies for assembling this motif. It covers a broad gamut of molecules, from small alkaloids to complex peptides.
\end{abstract}

From the Contents

1. Introduction

2. Structure and bioactivity

3. Syntheses of natural products containing HPI or HPIC

\subsection{Acid catalyzed cyclization}

\subsection{Sequential oxidation-cyclization}

\subsubsection{Bromination-cyclization}

3.2.2. Synthesis of 3a-hydroxy-HPIC

3.2.3. Phenylselenocyclization

\subsection{Alkylative cyclization}

3.3.1. Cyclization with electrophiles

3.3.2. Cyclization with nucleophiles

\subsection{Successive alkylation cyclization of oxoindoles}


3.5. Synthesis of HPI system by rearrangements processes

3.5.1. [3.3]-sigmatropic rearrangements

3.5.2. [1.2]-rearrangements

3.6. Formation of HPI by elaboration of indole heterocyclic ring

3.6.1 Reductive cyclization

3.6.2. Fischer Indole Synthesis

3.7. Synthesis of HPI by simultaneous formation of $N^{1}-C^{8 a}$ and $N^{8}-C^{8 a}$ bonds

3.8. Aza-Pauson-Khand cyclocarbonylation

3.9. Synthesis of natural products containing a $N^{\text {ind }}-C^{3 a}$ bond

4. Summary and Outlook 


\section{Introduction}

From the lushest forests to the deepest oceans, from the simplest organisms to the most complex, nature is replete with compounds containing either a hexahydropyrrolo[2,3-b]indole (HPI) unit, or the corresponding 2-carboxylate or 2-carboxamide (both abbreviated HPIC) (Figure 1). Biosynthetically, the simplest of these compounds stem from the amino acid Trp, whereas the more complex ones derive from Trp-containing peptides. Some HPI and HPIC-containing compounds contain two Trp or more units.

\section{Structure and bioactivity}

The first structures reported to contain HPI or HPIC were alkaloids; however, advances in the isolation and characterization of natural products later enabled identification of medium-sized cyclic peptides containing HPI or HPIC and exhibiting myriad biological activities. Some of these products are very small and are based around an HPI core, for example, (+)-alline (1), ${ }^{[1,2]}$ a small alkaloid with a hydroxyl group at $C^{3 a}$ and a methyl group at $N^{1}$. (-)-Physostigmine (2), isolated from the seeds of the Calabar bean plant (Physostigma venenosum) is a cholinesterase inhibitor. (-)Physostigmine is currently used to treat myasthenia gravis, glaucoma, Alzheimer's disease and delayed gastric emptying, and has recently been employed to treat orthostatic hypotension. ${ }^{[3]}$ Further examples of these compounds alkylated at $C^{3 a}$ include the flustramines A-M (3-7), a family of alkaloids isolated from the marine organism Flustra foliacea ${ }^{[4-9]}$ the flustramides $A, B(8)$, and $\mathrm{E} ;{ }^{[10,11]}$ dihydroflustramine C (9); ${ }^{[12]}\left(3 \mathrm{a} R^{\star}, 8 \mathrm{a} S^{\star}\right)$-6-bromo-3a-[(2E)-3,7-dimethyl-2,6-octadienyl]1,2,3,3a,8,8a-hexahydropyrrolo[2,3-b]indol-7-ol; ${ }^{[13]}$ debromoflustramines $\mathrm{B}^{[8]}$ and $\mathrm{H}^{;{ }^{[9]}}$ five recently discovered alkaloids isolated from the plant Selaginella moellendorfii; ${ }^{[14]}$ the flustraminols $A$ and $\mathrm{B},{ }^{[6]}$ both part of the flustramines family and characterized by a hydroxyl group at $C^{3 a}$; and (-)pseudophrynaminol (10), extracted from the Australian frog Pseudophryne coriacea ${ }^{[15]}$ (Figure 1).

The HPIC unit is found in products such as the okaramines A-Q (11), isolated from the fungus Penicillium simplicissum. ${ }^{[16-22]}$ In okaramines the HPIC is condensed to a diketopiperazine (DKP) unit formed from a second amino acid. Leptosins D-F $(\mathbf{1 2 - 1 4}),{ }^{[23]}$ gliocladines C-E (15-17), ${ }^{[24]}$ gliocladins $A-C,{ }^{[25]}$ plectosphaeroic acids A-C $(\mathbf{1 8}, \mathbf{1 9}),{ }^{[26]}(+)$-asperazine $(20),{ }^{[27]}$ and naseseazines $A$ and $B^{[28]}$ have an analogous DKP unit containing an extra indole, bound between $C^{3}$ and $C^{3 a}$ (except for in the case of $\left(+\right.$ )-asperazine and the naseseazines, in which the indole binds via $C^{7}$ and $C^{6}$ respectively). Brevicompanines $\mathrm{A}-\mathrm{H}(\mathbf{2 1}, \mathbf{2 2})$, allo-brevicompanine $\mathrm{B}$ and fructigenine $\mathrm{B}^{\text {[29-31] }}$ are also alkylated at $C^{3 a}$; as is ardeemin, isolated from a strain of Aspergillus fischeri; ${ }^{\left[{ }^{[2]}\right]}$ roquefortines $\mathrm{C}, \mathrm{D}(\mathbf{2 3}), \mathrm{F}$ and $\mathrm{G} ;{ }^{[33-36]}$ and aszonalenin $(\mathbf{2 4}) \cdot{ }^{[37]}$ Brevianamide $\mathrm{E}(\mathbf{2 5}),{ }^{[38]}$ the sporidesmins ${ }^{[39-42]}$ and notoamide $\mathrm{D}^{[43]}$ are all hydroxylated at $C^{3 a}$ (Figure 1). 


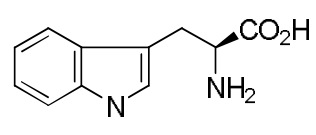

L-Trp

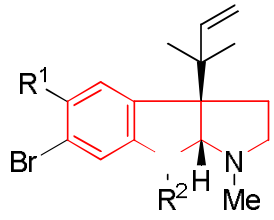

$\mathrm{R}^{1}=\mathrm{H}, \mathrm{R}^{2}=$ preny $; \mathbf{F I}$ strami e $\mathbf{A}(\mathbf{3})$ $R^{1}=$ prenyl, $R^{2}=H$; FI strami e D (5) $\mathrm{R}^{1}=\mathrm{H}, \mathrm{R}^{2}=\mathrm{Ac}$; FI strami e $\mathbf{F}$ (6) $\mathrm{R}^{1}=\mathrm{Br}, \mathrm{R}^{2}=\mathrm{H} ; \mathbf{F I}$ strami e $\mathbf{G}(7)$ $R^{1}=R^{2}=H$; Dihydrofl strami e C (9)

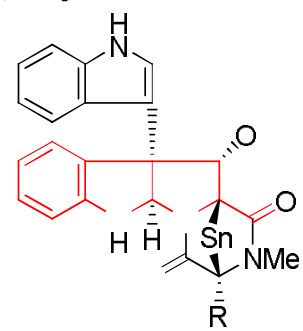

$\mathrm{R}=i-\mathrm{Pr}, \mathrm{n}=2 ;(+)$-Leptosin $\mathrm{D}(12)$ $\mathrm{R}=i-\mathrm{Pr}, \mathrm{n}=3$; $(+)$-Leptosin $\mathrm{E}(13)$ $\mathrm{R}=i-\mathrm{Pr}, \mathrm{n}=4$; (+)-Leptosin $\mathrm{F}(14)$ $\mathrm{R}=\mathrm{Me}, \mathrm{n}=2 ;(+)-\mathrm{G}$ iocladi e C (15) $R=$ Me, $n=3 ;(+)-G$ iocladi e $D(16)$ $R=M e, n=4 ;(+)-G$ iocladi e $E(17)$

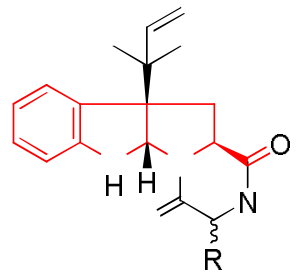

$\mathrm{R}=\mathrm{s}-\mathrm{Bu}$; (-)-Brevicomp ni e A (21) $\mathrm{R}=i-\mathrm{Bu}$; (-)-Brevicomp ni e $\mathrm{B}$ ( 2) $\mathrm{R}=\mathrm{CH}_{2}$-4-imid zoly ; (-)-Roq eforti e D ( 3)

HPI R= H
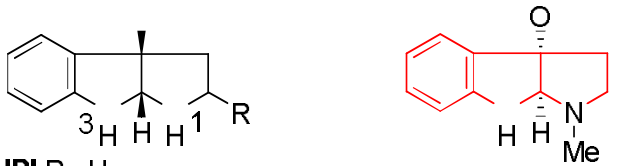

HPIC $\mathrm{R}=\mathrm{CO}_{2} \mathrm{H}$ or $\mathrm{COX}$

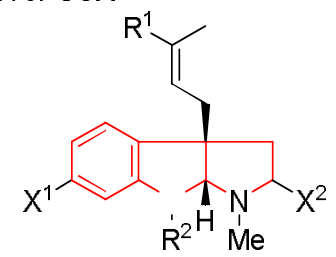

(+)-A li e (1)

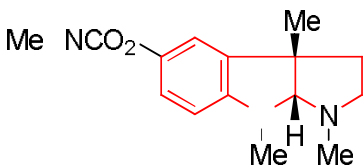

(-)Physostigmi e (2)

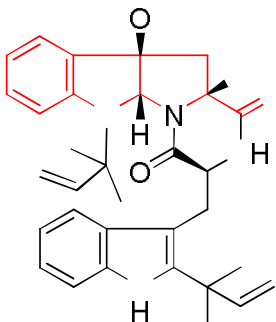

(+)-Okarami e C ( 1)<smiles>C=C1CCC(=O)C2C[C@](c3cccc4c(C[C@@H]5NC(=O)C(Br)CC5=O)c[nH]c34)(C3CCCCC3)c3ccccc3N[C@H]12</smiles>

(+)-Asperazi e ( 0) $\overline{\bar{B}}$

$\mathrm{R}^{1}=\mathrm{Me}, \mathrm{R}^{2}=$ prenyl, $\mathrm{X}^{1}=\mathrm{Br}, \mathrm{X}^{2}=\mathrm{H}, \mathrm{H}$; FI strami e $\mathbf{B}$ (4)

$\mathrm{R}^{1}=$ Me, $\mathrm{R}^{2}=$ prenyl, $\mathrm{X}^{1}=\mathrm{Br}, \mathrm{X}^{2}=\mathrm{O}$; FI stramide $\mathbf{B}$ (8)

$\mathrm{R}^{1}=\mathrm{CH}_{2} \mathrm{OH}, \mathrm{R}^{2}=\mathrm{X}^{1}=\mathrm{H}, \mathrm{X}^{2}=\mathrm{H}, \mathrm{H} ;(-) \mathbf{P}$ eudophry aminol (10)

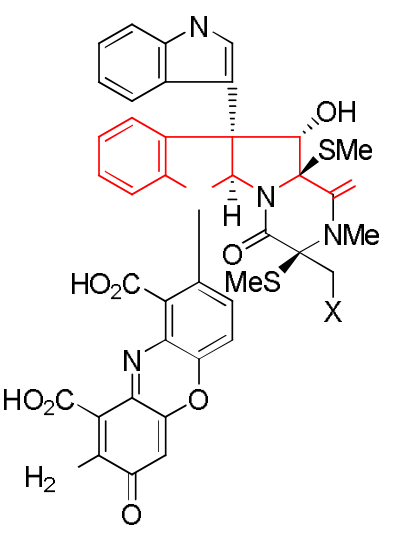

$\mathrm{X}=\mathrm{OH} ;(+)+\mathrm{PI}$ ctosph eroi acid $\mathrm{A}(18)$

$X=\mathrm{H} ;(+)+P I$ ctosph eroi acid $B(19)$
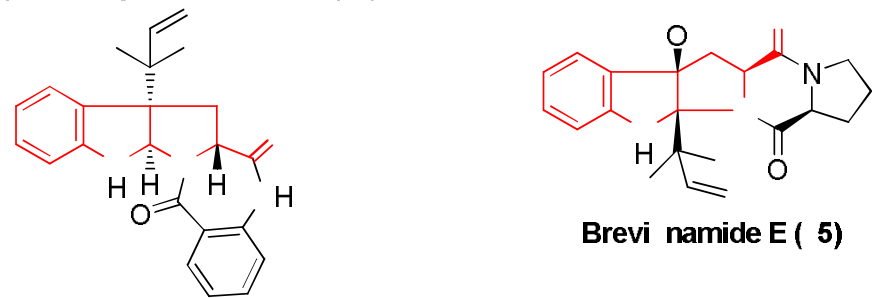

Brevi namide E ( 5)

Figure 1. Natural products containing a single HPI or HPIC unit (shown in red)

Natural compounds containing two or more HPI or HPIC units are shown in Figure 2. These include amauromine (26) and gypsetin (27), dimeric alkaloids in which two HPIC units are condensed through a DKP. Amauromine, obtained from the culture broth of Amauroascus sp, has vasodilating activity, ${ }^{[44,45]}$ and gypsetin is an inhibitor of acyl-CoA. ${ }^{[4,47]}$ Natural products containing two HPI units comprise the botanical compound (-)-chimonanthine $(\mathbf{2 8})^{[48-51]}$ or its optical antipode, (+)-chimonanthine, found in the skin of the Colombian poison dart frog, Phyllobates terribilis ${ }^{[49]}$ and in Psychotria colorata flowers. ${ }^{[52]}$ Chimonanthines are dimeric HPIs linked between the $\mathrm{C}^{3 \mathrm{a}}$ of each unit. Related compounds include (meso)-chimonanthine; ${ }^{[53]}$ (-)-chimonanthidine (29); ${ }^{[51]}$ (-)calycanthidine $(\mathbf{3 0}) ;^{[51]} N^{b}$-desmethyl-(meso)-chimonanthine; ${ }^{[50]}$ and the antifungal agent (-)folicanthine $(\mathbf{3 1})^{[54]}$ which was isolated from both Calycanthus floridus ${ }^{[55,56]}$ and the seeds of Chimonanthus praecox. ${ }^{[51]}$ The absolute configuration of (-)-31 was determined by chemical 
correlation with $(-)-28^{[51]}$ and the total synthesis of its enantiomer $(+)-31 .^{[57]}$ Furthermore, psycholeine ${ }^{[58]}$ (meso)-pseudophrynamine $A^{[15]}$ and the recently isolated flustramines $O(32)$ and $P$ (33) ${ }^{[9]}$ each have two HPI units (Figure 2).

Natural compounds containing more than two HPI units comprise idiospermuline $(34)^{[59]}$ and the hodgkinsines (35), ${ }^{[50,52,60,61]}$ with three HPI units; psychopentamine ${ }^{[62]}$ and quadrigemines $A, B, C$ (36), and I, ${ }^{[50,52,58,61,63]}$ with four. Quadrigemine $C$ is a weak antagonist of the SRIF (somatostatin) receptor, like psycholeine and (meso)-pseudophrynamine $A$. Isopsychotridines $A$ and $B(37)^{[61]}$ and psychotridine, with five $;{ }^{[50,61]}$ oleoidine, ${ }^{[50]}$ with six; and caledonine,${ }^{[50]}$ with seven.

Another important group comprises dimeric HPICs linked by the $C^{3 a}$ of each unit, each of which contains a DKP. These include the neurokinin antagonists (+)-WIN64821 (38) and (+)-WIN64745 (39), both isolated from a strain of Aspergillus sp. .64-66] $^{[-)-d i t r y p t o p h e n a l i n e ~(40), ~ o b t a i n e d ~ f r o m ~}$ Aspergillus flavus; ${ }^{[67]}$ the anti-viral agent (+)-asperdimin (41), isolated from extracts of Aspergillus niger ${ }^{[68]}$ chaetocin (42), isolated from the fermentation broth of Chaetomium minutum; ${ }^{[69]}$ verticillins A (43), B, and C, obtained from Verticillium sp., exhibit antimicrobial activity against Gram positive bacteria and potent antitumor activity in HeLa cell lines; ${ }^{[70-72]}$ gliocladines $A(44)$ and $B(45) ;{ }^{[24]}$ 11,11'-dideoxyverticillin $A$ and $11^{\prime}$-deoxyverticillin $A^{\left[{ }^{[24,73]}\right.}$ melinacidins; ${ }^{[74-76]}$ Sch52900 and Sch52901; ${ }^{[24]}$ and some leptosins A (46), B (47), and C (48). ${ }^{[23]}$ Leptosins C and F, isolated from the marine fungus Leptoshaeria sp., have inhibitory activity against topoisomerases I and II ${ }^{[7]}$ (Figure 2). 


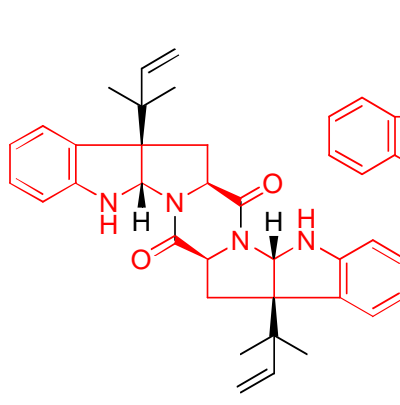

Amauromine (26)

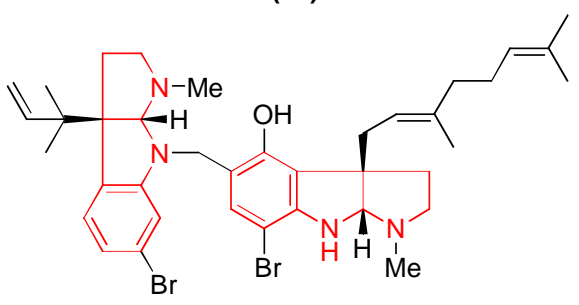

$$
\text { Gypsetin (27) }
$$

$\mathrm{R}^{1}=\mathrm{R}^{3}=\mathrm{H}, \mathrm{R}^{2}=\mathrm{Me}$; (-)-Chimonanthine (28) $\mathrm{R}^{1}=\mathrm{R}^{3}=\mathrm{Me}, \mathrm{R}^{2}=\mathrm{H}$; (-)-Chimonanthidine (29) $\mathrm{R}^{1}=\mathrm{R}^{2}=\mathrm{Me}, \mathrm{R}^{3}=\mathrm{H}$; (-)-Calycanthidine (30)

$R^{1}=R^{2}=R^{3}=M e ;(-)$-Folicanthine (31)

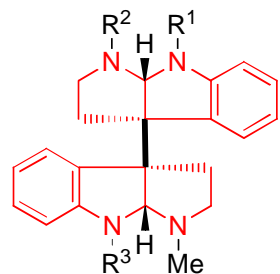

Flustramine P (33)

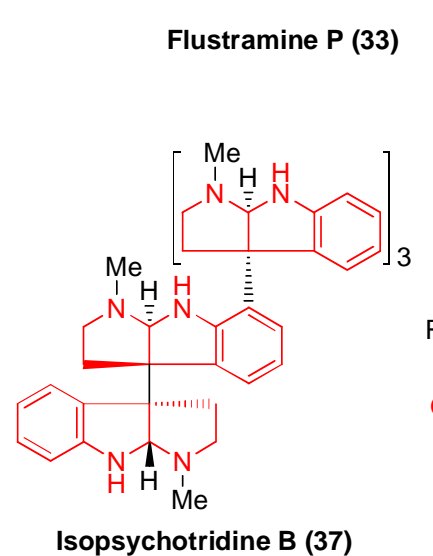

Isopsychotridine B (37)

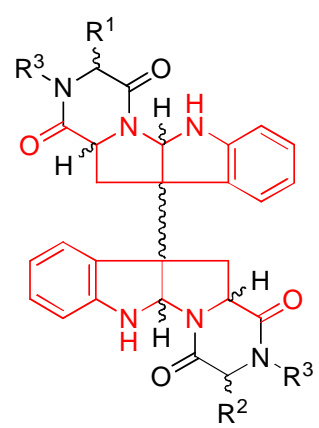

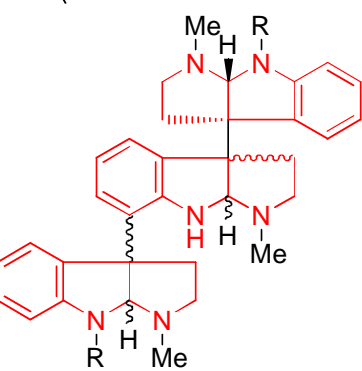

$\mathrm{R}=\mathrm{Me}$; Idiospermuline (34) $\mathrm{R}=\mathrm{H}$; Hodgkinsine (35)

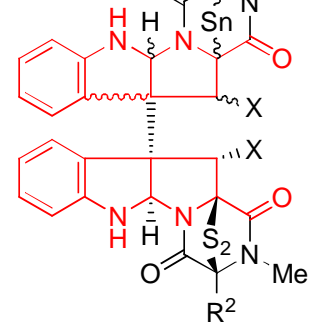

$\mathrm{R}^{1}=\mathrm{R}^{2}=\mathrm{CH}_{2} \mathrm{OH}, \mathrm{X}=\mathrm{H}, \mathrm{n}=2 ;$ Chaetocin (42)

$\mathrm{R}^{1}=\mathrm{R}^{2}=\mathrm{Me}, \mathrm{X}=\mathrm{OH}, \mathrm{n}=2$; Verticillin $\mathrm{A}$ (43)

$\mathrm{R}^{1}=\mathrm{R}^{2}=\mathrm{Me}, \mathrm{X}=\mathrm{OH}, \mathrm{n}=3$; Gliocladine $\mathrm{A}(44)$

$\mathrm{R}^{1}=\mathrm{R}^{2}=\mathrm{Me}, \mathrm{X}=\mathrm{OH}, \mathrm{n}=4$; Gliocladine $\mathrm{B}$ (45)

$\mathrm{R}^{1}=\mathrm{CH}_{2} \mathrm{OH}, \mathrm{R}^{2}=i-\mathrm{Pr}, \mathrm{X}=\mathrm{OH}, \mathrm{n}=2 ;(+)$-Leptosin $\mathrm{A}(46)$

$\mathrm{R}^{1}=\mathrm{CH}_{2} \mathrm{OH}, \mathrm{R}^{2}=i-\mathrm{Pr}, \mathrm{X}=\mathrm{OH}, \mathrm{n}=3 ;(+)$-Leptosin $\mathrm{B}(47)$

$\mathrm{R}^{1}=\mathrm{CH}_{2} \mathrm{OH}, \mathrm{R}^{2}=i-\mathrm{Pr}, \mathrm{X}=\mathrm{OH}, \mathrm{n}=4 ;(+)$-Leptosin $\mathrm{C}(48)$

$R^{1}=R^{2}=B n, R^{3}=H ;(+)$-WIN 64821 (38)

$\mathrm{R}^{1}=\mathrm{Bn}, \mathrm{R}^{2}=i-\mathrm{Bu}, \mathrm{R}^{3}=\mathrm{H} ;(+)$-WIN 64745 (39)

$\mathrm{R}^{1}=\mathrm{R}^{2}=\mathrm{Bn}, \mathrm{R}^{3}=\mathrm{Me}$; (-)-Ditryptophenaline (40)

$\mathrm{R}^{1}=i-\mathrm{Bu}, \mathrm{R}^{2}=i-\operatorname{Pr}, \mathrm{R}^{3}=\mathrm{H}$; (+)-Asperdimin (41)

Figure 2. Natural products containing two or more HPI or HPIC units (shown in red)

Several recently isolated products feature a bond between the $C^{3 a}$ of an HPI or HPIC unit and the $\mathrm{N}^{\text {ind }}$ of a modified tryptamine or Trp, such as that found in the alkaloid psychotrimine (49). ${ }^{[62]}$ Another noteworthy example is the epipolythiodioxopiperazine family, whose members exhibit numerous bioactivities, including antitumor, antimicrobial, antinematodal and cytotoxicity; notable members include the chetomin (50), chaetocochins A (51), B (52), and C, and dethiotetra(methylthio)chetomin, all isolated from the solid-state fermented rice culture of the fungus Chaetomium cochliodes. ${ }^{[78-84]}$ An extra degree of complexity is shown in kapakahines $C(53)$ and $D$ (54), which are macrocyclic peptides formed through a bond between the $\mathrm{N}^{8}$ of an HPIC located at the $\mathrm{N}$-terminal of the linear structure and the $\mathrm{C}^{4 \mathrm{a}}$ of an $\alpha$-carboline unit, located close to the $\mathrm{C}$ terminal. ${ }^{[85]}$ 


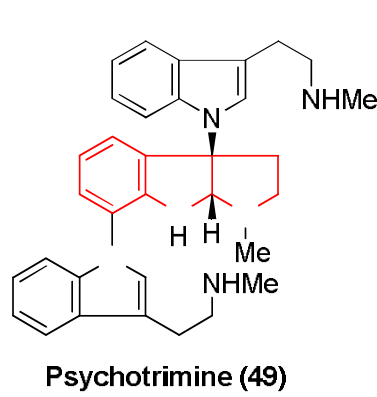

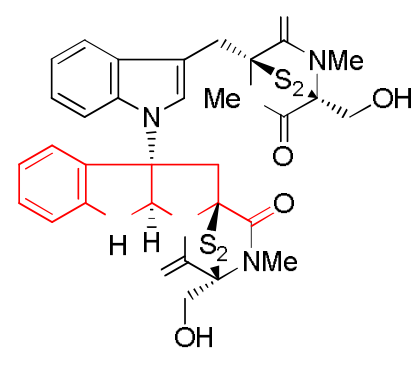

Chetomin (50)

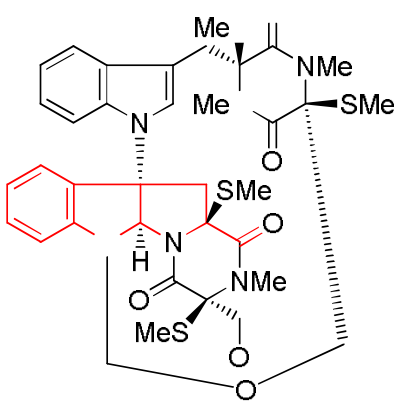

Ch etocochin A (51)

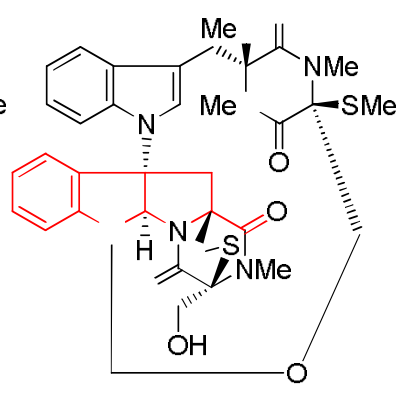

Ch etocochin B (52)
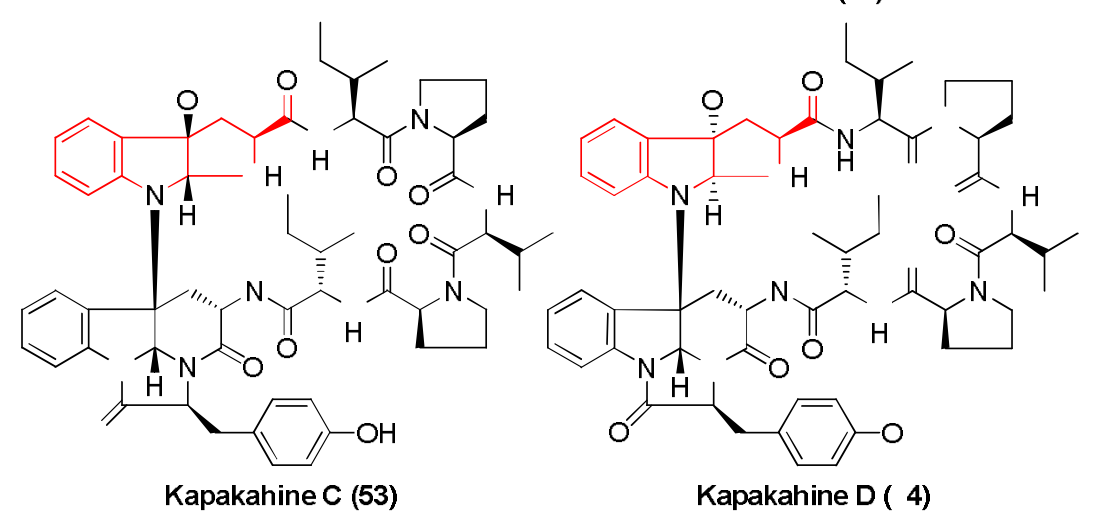

Kapakahine $D$ ( 4)

Figure 3. Natural products containing an HPI or HPIC unit (show in red) bound through $C^{3 a}$ to the $N$ of an HPIC unit, tryptamine or Trp

Natural products with an HPIC integrated into the peptide chain include omphalotins B-I (55), ${ }^{[66,87]}$ phakellistatin $3(56)$ and isophakellistatin $3 ;{ }^{[88]}$ himastatin (57), in which the HPIC is part of a depsipeptide-chain; ${ }^{[89,90]}$ its structure and stereochemistry was revised after the total synthesis. ${ }^{\left[{ }^{[1,92]}\right.}$ Other similar natural products are chloptosin $(58) ;{ }^{[93]} \mathrm{NW}-\mathrm{G} 01$, an antibiotic isolated from Streptomyces alboflavus; ${ }^{[94]}$ and kutznerides 1-9 (59) ${ }^{[95,96]}$ (Figure 4). 


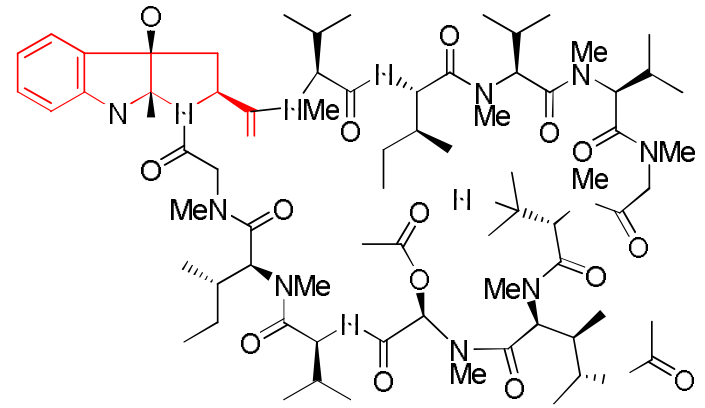

Omphalotin D ( 5)

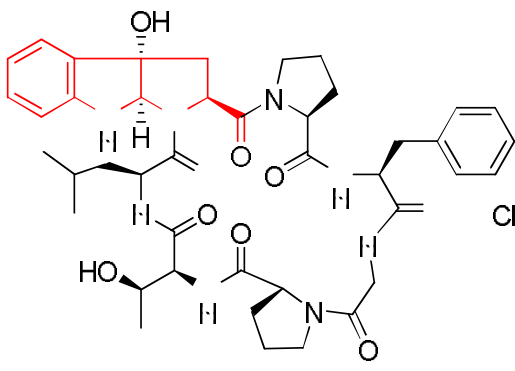

Phake listatin 3 ( 5)

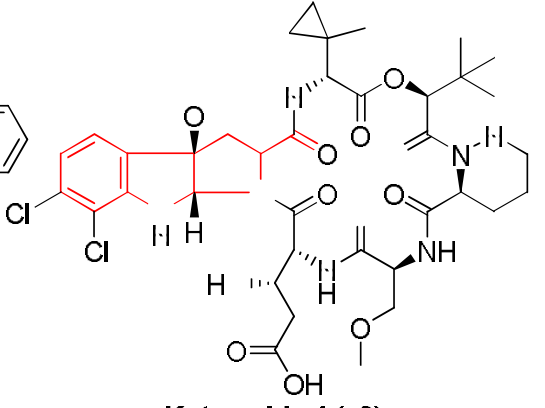

Kutz oride 1 ( 5)

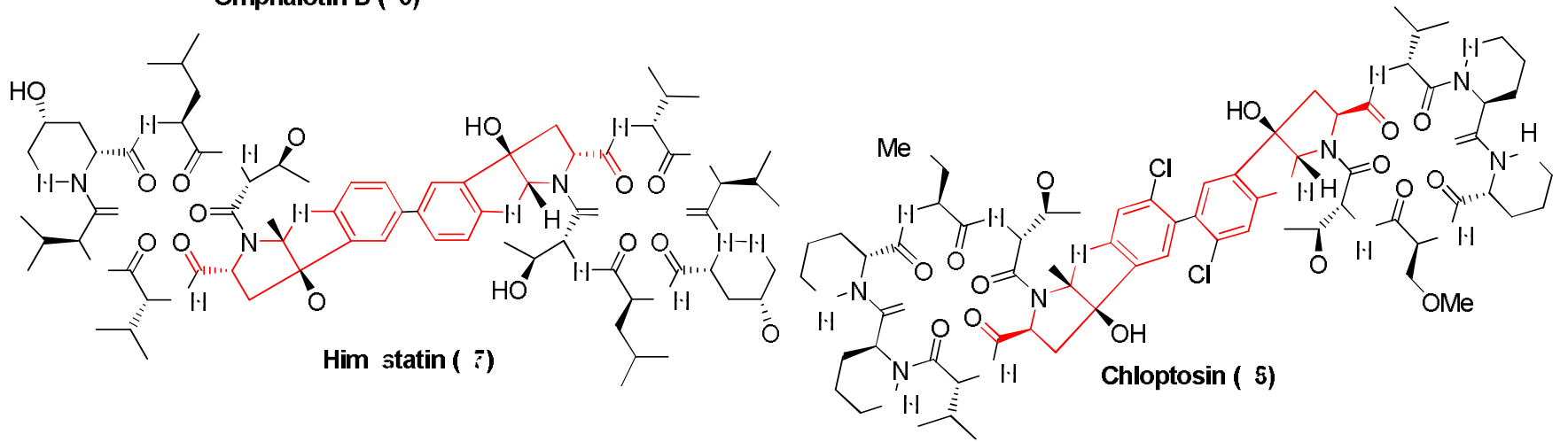

Figure 4. Natural products containing HPIC (shown in red) as part of a peptide chain

Most of these complex structures have only recently been isolated. The literature contains a few reviews, although these cover only specific aspects of these compounds. These include works by Schmidt and Movassaghi, ${ }^{[97]}$ on biosynthetic hypotheses; Steven and Overman, ${ }^{[98]}$ on syntheses of poly-HPI compounds; and Crich and Banerjee, ${ }^{[99]}$ on the stereochemistry of HPI containingcompounds, as well as classical publications on the Calabar bean alkaloids, ${ }^{[100,101]}$ phenserine,${ }^{[102]}$ chimonanthine and related natural products, ${ }^{[103,104]}$ chaetocin and related natural products, ${ }^{[105]}$ and the chemistry of cyclic tautomers of tryptamines and Trp. ${ }^{[106,107]}$

This article provides an exhaustive overview of the structure, synthesis and bioactivity of HPI and HPIC containing natural products from all of the aforementioned structural classes, emphasizing the synthetic routes to polycyclic compounds of this type published until December 2009. Alkaloids containing a poly-HPI linked at the quaternary carbons, such as quadrigemine $\mathrm{C}$, have been omitted here because they have already been covered in an excellent report by Steven and Overman. ${ }^{[98]}$

\section{Syntheses of natural products containing HPI or HPIC}

Several procedures have been developed for the synthesis of HPI and HPIC units, chiefly in the context of natural product syntheses. Figure 5 illustrates known routes to tricyclic HPI and HPIC. 


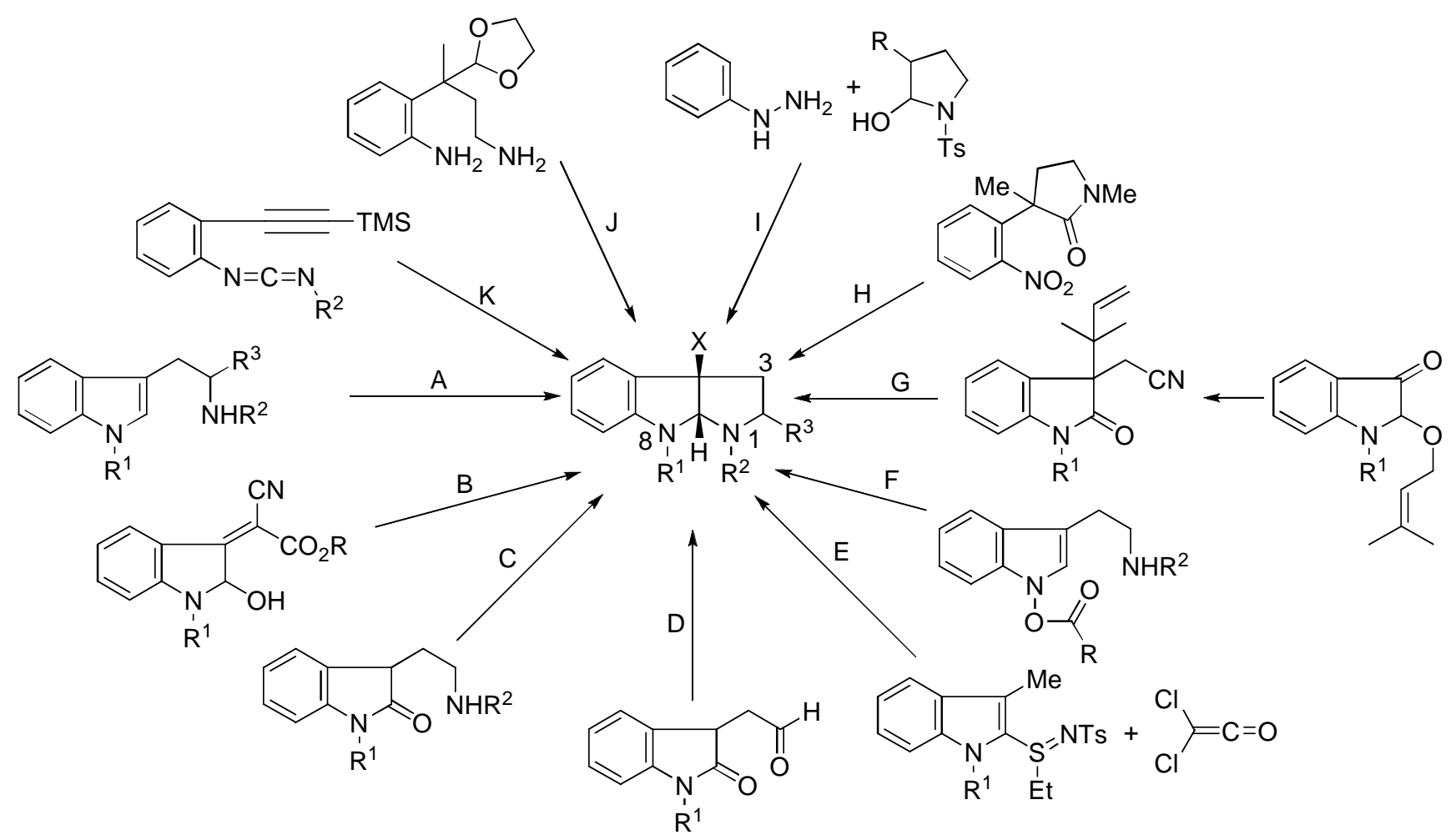

Figure 5. Synthetic strategies for constructing tricyclic HPI and HPIC

The most widely used starting materials for the synthesis of tricyclic HPI and HPIC are functionalized indoles (or oxidized indoles), tryptamines or Trp's (see Fig. 5). Routes A through C comprise bond formation between $N^{1}$ and $C^{8 a}$. In Route $\mathrm{D}$, the bonds $C^{8 a}-N^{1}$ and $C^{2}-N^{1}$ are formed from a diketo-derivative of indole. Route $\mathrm{E}$ entails introduction of $C^{2}$ by formation of the bonds $N^{1}$ $C^{2}$ and $C^{2}-C^{3}$, using dichloroketene and an indolyl sulfylimine. In Route $\mathrm{F}, \mathrm{HPI}$ is performed by reductive cyclization. Route $\mathrm{G}$ affords $\mathrm{HPI}$ after the rearrangement of an acyloxy group. Route $\mathrm{H}$ involves bond formation between $N^{\beta}$ and $\mathrm{C}^{8 \mathrm{a}}$ from a 3-(nitrocyclohex-1-enyl)pyrrolidin-2-one. Route I comprises Fischer indolization, namely, via condensation of phenylhydrazines with latent aldehydes. Route $\mathrm{J}$ involves simultaneous formation of the bonds $N^{8}-C^{8 a}$ and $N^{1}-C^{8 a}$. Lastly, Route $\mathrm{K}$, in which HPIC is assembled via formation of the bonds $C^{3 a}-C^{8 a}$ and $N^{1}-C^{2}$, is based on the azaPauson-Khand reaction (APKR).

\subsection{Acid catalyzed cyclization}

In Route A (Figure 5), HPIC ring closure is acid catalyzed. This involves protonation of indole at $\mathrm{C}^{3}$, followed by capture of the resulting indoline by the protected amine of the lateral chain. This procedure has been extensively used, starting from protected tryptamine, Trp or even more complex compounds. 
The Trp derivative 60 cyclized in $85 \% \mathrm{H}_{3} \mathrm{PO}_{4}$ to yield two diastereomers of the corresponding HPIC in a thermodynamic ratio of 9:1 (61:62, endo:exo). ${ }^{[108]}$ However, if these products are not stabilized in solution by acylation or sulfonylation of $N^{8}$, they degenerate back to the starting material (Scheme 1). ${ }^{[106]}$

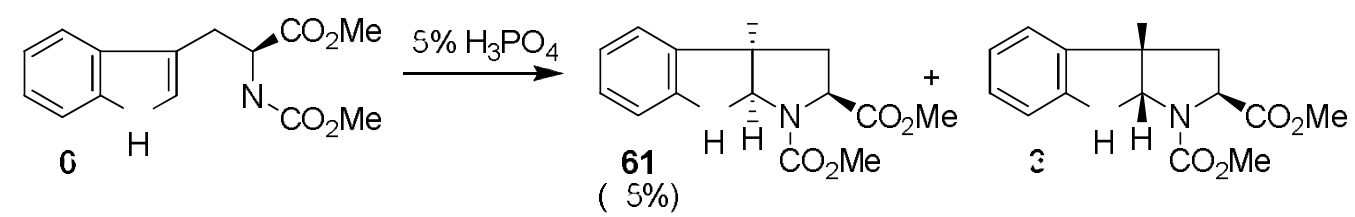

Scheme 1. Acid-catalyzed cyclization of $N$-protected-L-Trp $60^{[108]}$

A solution of $N^{\alpha}$-methoxycarbonyl-L-Trp 60 in trifluoroacetic acid (TFA) gave, after equilibration, mainly the endo-HPIC 61 plus minor amounts of the exo-HPIC 62 and starting material. Addition of trifluoroacetic acid anhydride (TFAA) to the solution afforded the two corresponding trifluoroacetyl analogs. ${ }^{[109]}$

Treatment of 60 with TFAA in dry pyridine afforded a complex mixture. The main constituents were the adduct $63(50 \%)$ and the $N^{\text {ind }}$-trifluoroacetylated Trp 64. ${ }^{[10]}$ The exact structure of 63 , including the stereochemistry of its three stereogenic centers, were unequivocally established by X-ray analysis (Scheme 2). ${ }^{[111]}$

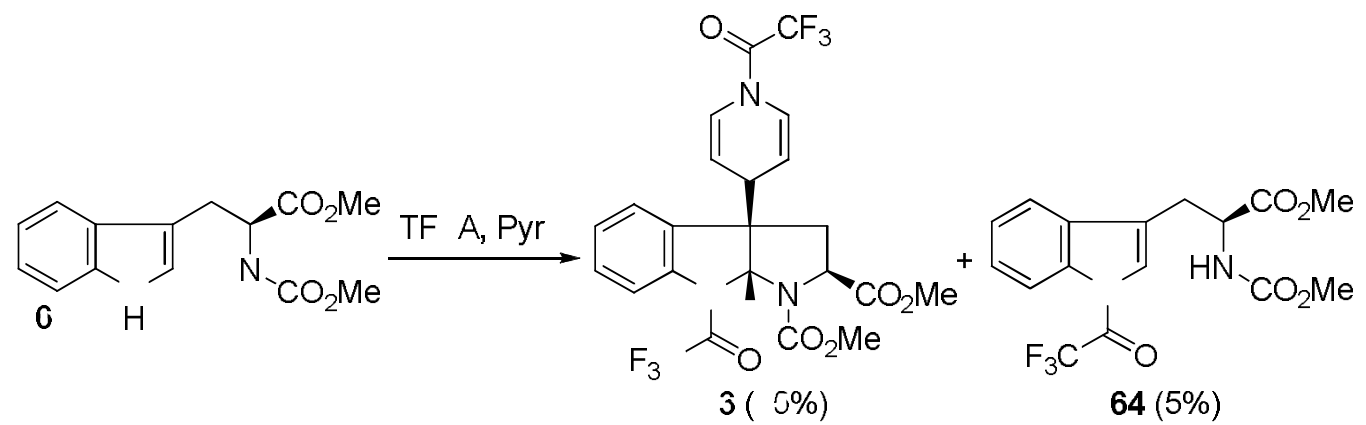

Scheme 2. Cyclization of protected $N$-protected-L-Trp $60^{[110]}$

Crich described a diastereoselective synthesis of the non-naturally occurring (+)debromoflustramine $B(69)$ and related compounds from the L-Trp-derived HPIC 65. ${ }^{[12]}$ Diastereomerically and enantiomerically pure sulfonamide 65 obtained by phenylsulfonylation of 61 was used to prepare HPI alkaloids. The main transformations comprised functionalization and C-C bond formation at $\mathrm{C}^{3 a}$; Barton ${ }^{[113]}$ reductive decarbomethoxylation at $\mathrm{C}^{2}$; and sequential selective deprotection and alkylation of the two nitrogen centers (Scheme 3). 


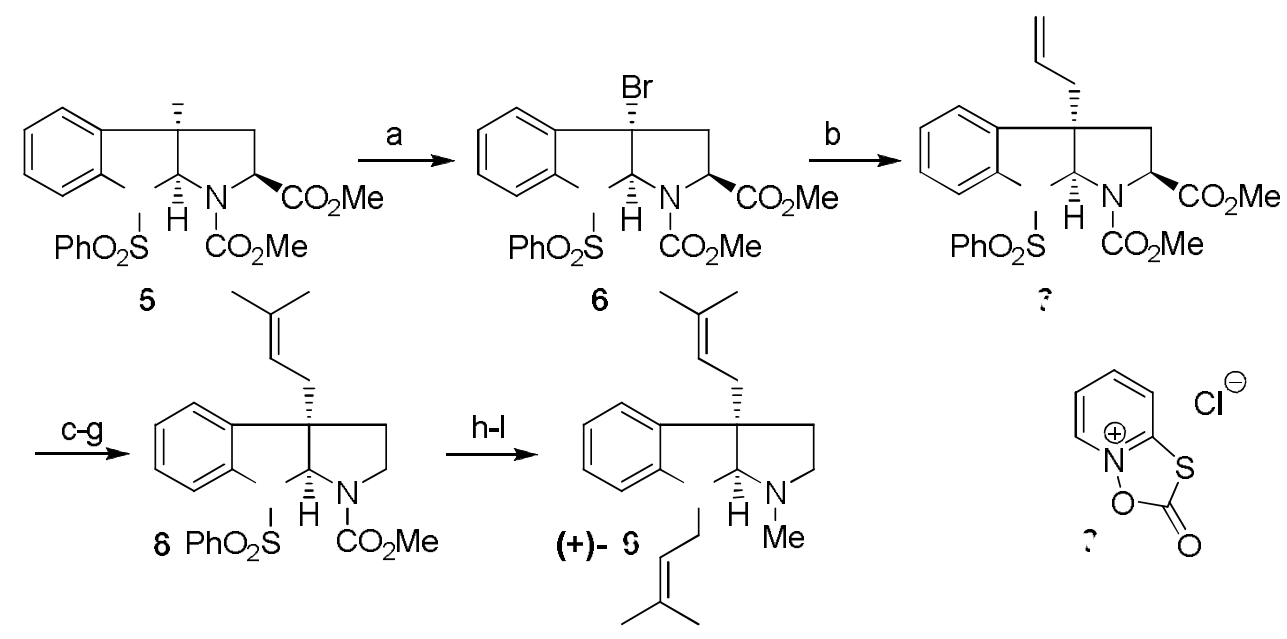

$\mathrm{R}$ agents: a. NBS, $\mathrm{Cl}_{4}, \Delta, 60-: \%$; b. $\mathrm{Bu}_{3} \mathrm{SnCH}_{2} \mathrm{CH}=\mathrm{CH}_{2}, \Delta, \quad 0 \% ; \mathrm{c}$. $\mathrm{NaIO}_{4}, \mathrm{OsO}_{4}, 3 \%$; d. $\mathrm{Ph}_{3} \mathrm{P}=\mathrm{CMe}_{2}, \quad 3 \%$; e. $\mathrm{KOH}, \mathrm{MeOH}, 3 \%$; f. $\quad \therefore \mathrm{Et}_{3} \mathrm{~N}$; g. $t$-Bu $\rightarrow, \mathrm{hv}, 61 \%$ (2 steps); h. $\mathrm{KOH}, \mathrm{MeOH}, \wedge, 3 \%$ i. $\mathrm{NaBH}_{3} \mathrm{CN}, \mathrm{HCHO}, \mathrm{AcOH} ; \mathrm{j}$. $\mathrm{KOH}, \mathrm{MeOH}, 3 \%$ (2 steps); k. Na, $\mathrm{H}_{3}$ I. prenyl bromide, :\% (2 steps)

Scheme 3. Synthesis of (+)-debromoflustramine B (69) by Crich $^{[112]}$

\subsection{Sequential oxidation-cyclization (A, Figure 5)}

This methodology exploits the reactivity of compounds such as tryptamine or Trp at their 3substituted indole position to oxidants such as 2,2-dimethyldioxirane (DMDO), $\mathrm{N}$-bromosuccinimide (NBS), and phenylselenyl chlorides, whereby the resulting imine or iminium salt intermediate is captured by the lateral nitrogen.

\subsubsection{Bromination-cyclization}

Witkop et al. prepared the tricyclic pyrrolo[2,3-b]indoles 73 and $\mathbf{7 4}$ by reacting Trp $\mathbf{7 1}$ and tryptamine $\mathbf{7 2}$, respectively, with NBS at $\mathrm{pH} 9.2$ in a very dilute solution at room temperature. ${ }^{[114,115]}$

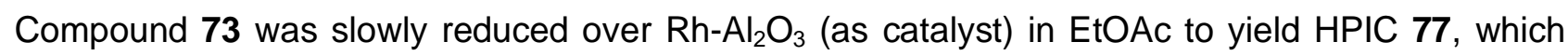
was then acetylated with $\mathrm{Ac}_{2} \mathrm{O}$ in pyridine to give 78. Reaction of $t$ - $\mathrm{BuOCl}$ with 73 gave the unstable 3a-chloroindolenine 75. Analogously, oxidation of 73 with $\mathrm{Pb}(\mathrm{OAc})_{4}$ in $\mathrm{DCM}$ gave the 3aacetoxyindolenine 76, which was rapidly reduced by $\mathrm{NaBH}_{4}$ in $\mathrm{MeOH}$ to the $3 a$-acetoxyindoline 79, which in turn was converted to the corresponding diacetyl derivative $\mathbf{8 0}$ for structural characterization (Scheme 4). 


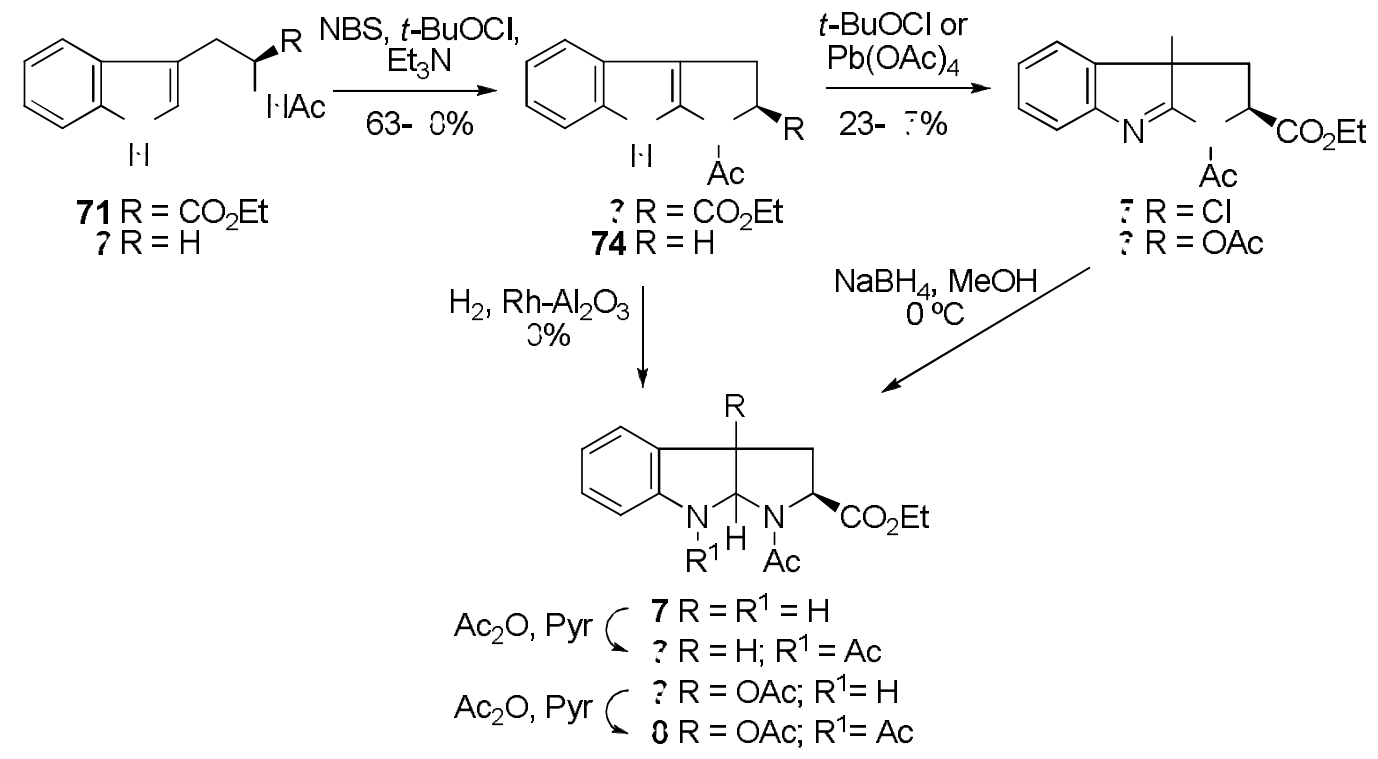

Scheme 4. Cyclization of tryptamine and Trp by Witkop et al. ${ }^{[14]}$

Lobo and Prabhakar reported a total synthesis of (-)-debromoflustramine B (69) from the Witkop HPIC 81 (Scheme 5). ${ }^{[16,117]}$ Their route starts with consecutive $C^{3 a}$-allylation of $\mathbf{8 1}$, followed by reduction and $N^{\beta}$-allylation to afford a diastereomeric mixture of endo and exo methyl esters. These esters had to be transformed into the corresponding Barton esters ${ }^{[118]}$ for separation. Oxidative removal of 2-carboxylate from exo-83 using $\mathrm{Sb}(\mathrm{SPh})_{3}$, followed by reduction, $N^{1}$ deprotection and methylation furnished (-)-69. Likewise, endo-83 gave (+)-69 (not shown).

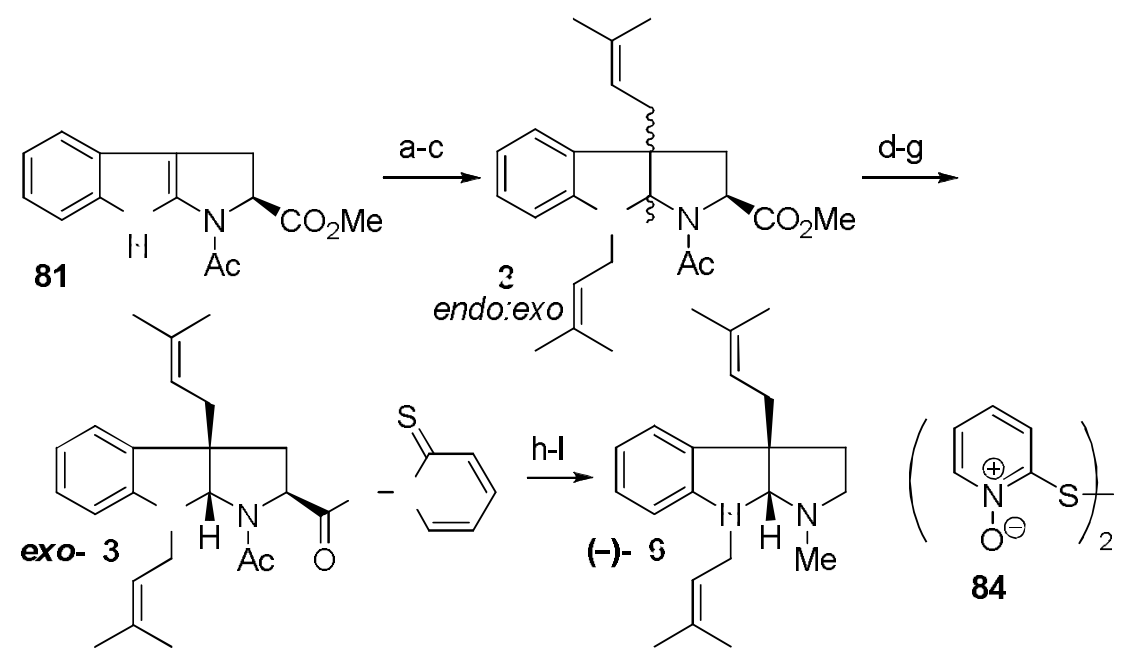

R egents: a. $\mathrm{NaH}, \mathrm{DMF}$, prenyl bromide, $60 \%$; b. $\mathrm{NaBH}_{3} \mathrm{CN}, \mathrm{MeOH}, 5 \%$; c. $\mathrm{K}_{2} \mathrm{CO}_{3}, \because \mathrm{F}$, prenyl bromide, $71 \%$; d. $\mathrm{NaOH}$, aq. $\mathrm{MeOH} ;$ e. $\mathrm{H}_{3} \mathrm{O}^{+}$; f. 84, $\mathrm{Pu}_{3}$, $\mathrm{CH}_{2} \mathrm{Cl}_{2}, 0^{\circ} \mathrm{C}$, $2 \%$ (3 steps); g. diaster omeri separation; h. $\mathrm{Sb}(\mathrm{SPh})_{3}, \mathrm{O}_{2}$, $\mathrm{Et}_{2} \mathrm{O}, 0$ to $18^{\circ} \mathrm{C}, 4 \%$;. xylene, $\Delta, 2 \%$; j. 4.7M NaMeO, $\mathrm{MeOH}, \quad \mathrm{l} \cdot \mathrm{H}_{2} \quad \mathrm{l} \cdot \mathrm{l}_{2}$, $\mathrm{H}_{2} \mathrm{O}, \Delta, 54 \% ; \mathrm{k} . \mathrm{LiAlH}_{4} \mathrm{Et}_{2} \mathrm{O}, 0^{\circ} \mathrm{C}, 70 \% ; \mathrm{NaH}$, Mel, $\because \mathrm{F}, \therefore \%$

Scheme 5 . Total synthesis of (-)-debromoflustramine B $(69)^{[116]}$ 
Using $\mathrm{Br}_{2}$ or NBS without base enabled bromination-cyclization of protected Trp or derivatives. Danishefsky et al. pursued NBS cyclization ${ }^{[91,119]}$ in preliminary studies on the total synthesis and structural characterization of himastatin. In the total synthesis of (+)-11,11'-dideoxyverticillin $A$, Movassaghi et al. used bromine and acetonitrile to obtain 3a-bromo-HPIC. ${ }^{[120]}$ De Lera et al. studied the mechanism and proposed the use of electrophiles such as NBS to obtain the bromocyclized product. ${ }^{[121]}$

\subsubsection{Synthesis of 3a-hydroxy-HPIC}

Photochemical oxidation of $N^{\alpha} N^{\text {ind }}$-dimethyltryptamine (85) in $\mathrm{CH}_{2} \mathrm{Cl}_{2}$ using pyridine $N$-oxide as oxygen source afforded the HPI $( \pm)-87^{[122]}$ The proposed mechanism involves opening of intermediate 2,3 -oxide 86 by methylamine residue (Scheme 6 ).

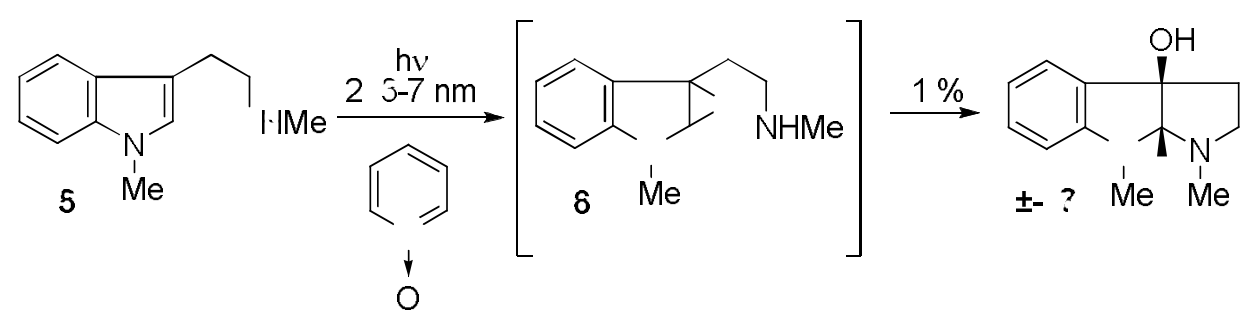

Scheme 6. Photochemical oxidation of $N^{\alpha} N^{\text {ind }}$-dimethyltryptamine (85) by pyridine $N$-oxides ${ }^{[122]}$

Photocyclization of $\mathrm{N}$-methoxycarbonyltryptamine in the presence of (-)-nicotine followed by treatment with triphenylphosphine produced 3-hydroxy-1-methoxycarbonyl-HPI with modest enantioselectivity. ${ }^{[123]}$ Similar results were obtained using protected Trp.

Danishefsky et al. developed a route to 3a-hydroxy-HPIC based on oxidative cyclization of Trp, ${ }^{\text {[92] }}$ in work on the total synthesis of himastatin (57). They also revised and confirmed stereochemistry of the natural product. The tert-butyl ester of $N^{\alpha}$-Tr-L-Trp (88) reacts with DMDO to give 89. Protecting groups exchange and iodination at position 5 gave $\mathbf{9 0}$ which was later dimerized. (Scheme 7)

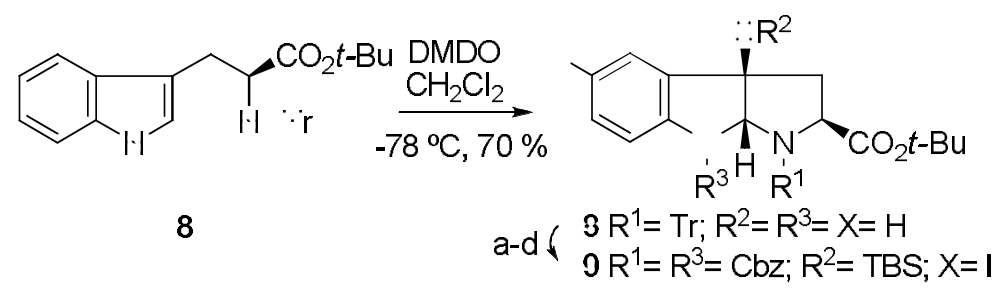

R egents: a. $\mathrm{AcOH}, \mathrm{MeOH}, \mathrm{CH}_{2} \mathrm{Cl}_{2} ;$ b. $\mathrm{CbzCl}, \mathrm{Pyr}, \mathrm{CH}_{2} \mathrm{Cl}_{2} ; \mathrm{c}$.

TBSCI, DBU, MeCN; d. ICl, 2,6-di-tert-butyl :ridine, $\mathrm{CH}_{2} \mathrm{Cl}_{2}, 75 \%$

Scheme 7. Tandem oxidation-cyclization of Trp by Danishefsky et al. ${ }^{[2]}$

Oxidative cyclization was the key step in the enantioselective total synthesis of the complex alkaloid okaramine $\mathrm{N}(\mathbf{9 3})$ by Corey et al. ${ }^{[124]}$ They developed a new method for the selective 
differentiation of the two indole subunits of 91 . The commercially available reagent $N$-methyl-1,3,4triazoline-2,5-dione (MTAD) was used in a novel application: reversible blocking of the $N$ unsubstituted indole subunit, which enabled oxidative ring-closure between the DKP and the $N$ substituted indole ring. The bisindole 91 underwent highly selective reaction with MTAD to form exclusively the ene product at $\mathrm{C}^{3}$ of the $\mathrm{N}$-unsubstituted indole subunit. Subsequent photooxidation, employing methylene blue as photosensitizer under sunlamp irradiation, followed by reduction of the resulting product by $\mathrm{Me}_{2} \mathrm{~S}$ in $\mathrm{MeOH}$, afforded the hydroxylated octacycle 92 cleanly (with only a minor amount of diastereomer). The blocking group was eliminated by thermolysis of the mixture of $\mathbf{9 2}$ and the diastereomer to furnish $\mathbf{9 3}$ in good total yield (Scheme 8).

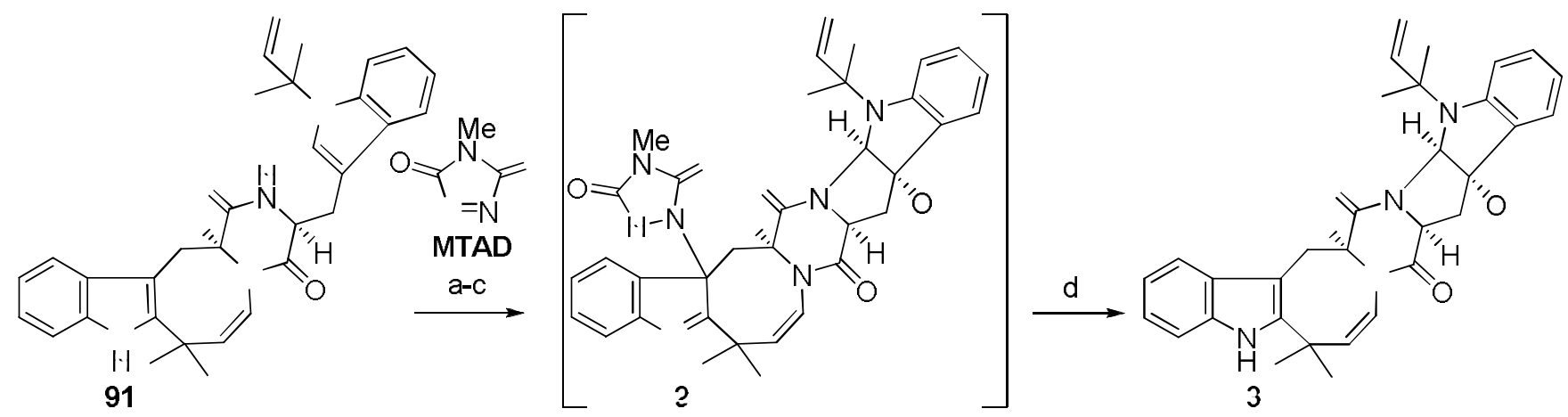

$\mathrm{R}$ agents: a. MTAD, $\mathrm{CH}_{2} \mathrm{Cl}_{2},-5^{\circ} \mathrm{C}$; b. $\mathrm{O}_{2}$, hv, $\mathrm{MeOH}$, methylene blue, $-28^{\circ} \mathrm{C}$; c. $\mathrm{SMe}_{2}, \mathrm{MeOH},-28$ to $-10^{\circ} \mathrm{C}$; d. $10^{\circ} \mathrm{C}$, $70 \%$ (4 steps)

Scheme 8. Enantioselective synthesis of okaramine $N(\mathbf{9 3})^{[124]}$

\subsubsection{Phenylselenocyclization}

The total synthesis of amauromine 26 from 95 (Scheme 9) has been reported. The keystone of this approach was kinetic stereoselective synthesis of 95 from $N^{i}, N^{\alpha}$-diBoc protected L-Trp methyl ester via selenocyclization reaction. ${ }^{[125]}$ Treatment of protected Trp 94 with $N$-phenylselenophthalimide (N-PSP) and pyridinium p-toluenesulfonate (PPTS) gave 95. The synthesis of 95 was the first construction of exo-HPIC from a protected Trp in a high diastereoselective manner. Transformation of phenylselanyIHPIC 95 with methyl trifluoromethanesulfonate (MeOTf) in the presence of 2,6di(tert-butyl)pyridine and prenyltri( $n$-butyl)tin gave the angular reverse prenyl derivative $\mathbf{9 7}$. 


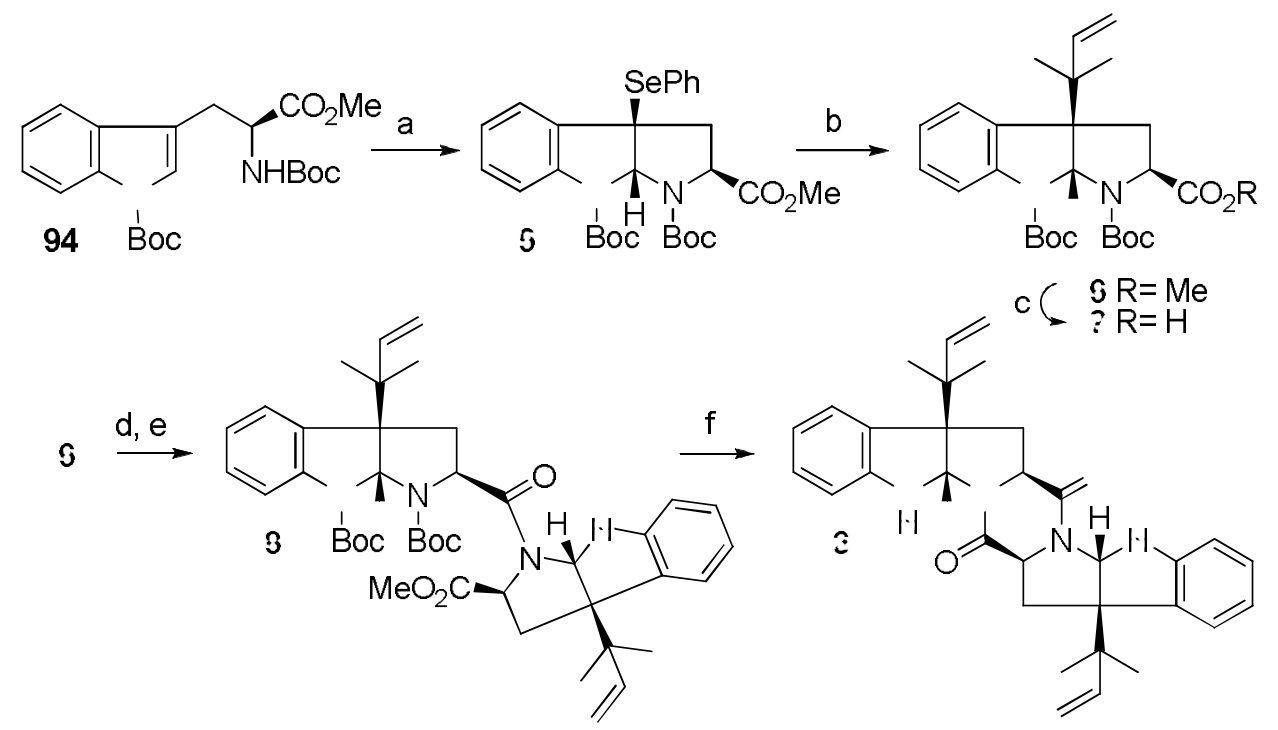

$\mathrm{R}$ agents: a. N-PSP, $\mathrm{CH}_{2} \mathrm{Cl}_{2}, \quad \mathrm{P} \doteqdot, \quad 3 \%$; b. MeOTf, 2,6-di(tert-butyl)pyridine, $\mathrm{Me}_{2} \mathrm{C}=\mathrm{CHCH}_{2} \mathrm{SnBu}_{3}, \mathrm{CH}_{2} \mathrm{Cl}_{2}-?{ }^{\circ} \mathrm{C}$ to reflux, 60\% (9:1 exo- ndo); c. $\mathrm{NaOH}, \because \mathrm{F}$, $\mathrm{MeOH}, \mathrm{H}_{2} \mathrm{O}$, reflux, $3 \%$; d. TMSI, $\mathrm{MeCN}, \mathrm{O}^{\circ} \mathrm{C}, 3 \%$; e. ?, $\mathrm{BOP}-\mathrm{Cl}, \mathrm{Et}_{3} \mathrm{~N}, \mathrm{CH}_{2} \mathrm{Cl}_{2}, 5 \%$; f. TMSI, MeCN, $0^{\circ} \mathrm{C}, 5 \%$

Scheme 9. Total synthesis of amauromine $(\mathbf{2 6})^{[125]}$

Roquefortine D (23) was prepared from the inverse prenylated-HPI 97, which was reacted with protected His under peptide coupling conditions followed by removal of both $\mathrm{N}$-tert-butoxycarbonyl (Boc) groups, cyclization, and finally, photolytic elimination of the o-nitrobenzyl protecting group (ONB) of the resulting imidazole. ${ }^{[126,127]}$

Ley et al. described a path to stereocontrolled synthesis of the 3a-hydroxypyrrolo[2,3-b]indole skeleton (Scheme 10). ${ }^{[128]}$ The procedure is based on a two-step selenocyclization-oxidative deselenation sequence. Treatment of 99 in the conditions described by Danishefsky ${ }^{[125]}$ gave $\mathbf{1 0 0}$ as a simple diastereomer with an excellent yield. The following oxidation with $m$-chloroperbenzoic acid (mCPBA) gave the desired product exo-101.
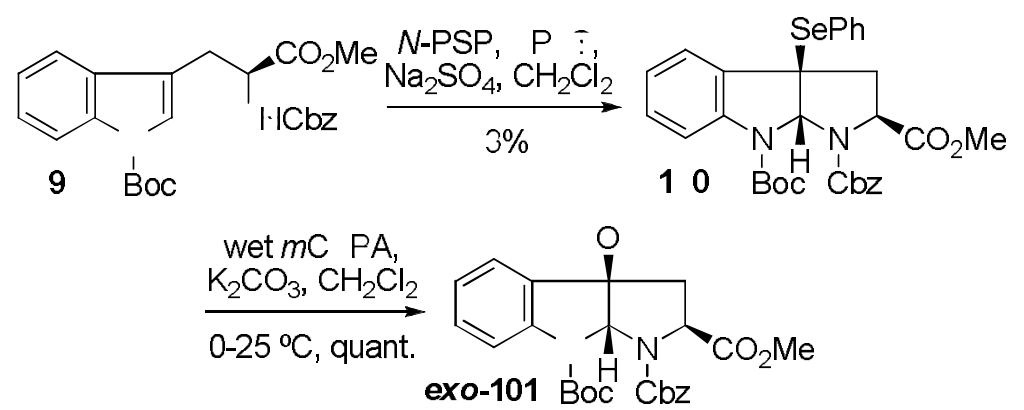

Scheme 10. Two-step route to 3a-hydroxy HPIC exo-101 by Ley et al. ${ }^{[128]}$

The same group later used this two-step sequence in an elegant and concise total synthesis of (+)okaramine $C(\mathbf{1 1})$ by epimerization at $C^{2}$ of $\mathbf{1 0 0}$ to obtain endo-101, formation of the DKP with the Trp 104 and introduction of isoprenyl on $N^{8}$ (Scheme 11). Isoprenyl group was afforded after partial reduction of the alkyne introduced by $N^{8}$-alkylation using 2-bromo-2-methylbut-3-yne. ${ }^{[29]}$ 


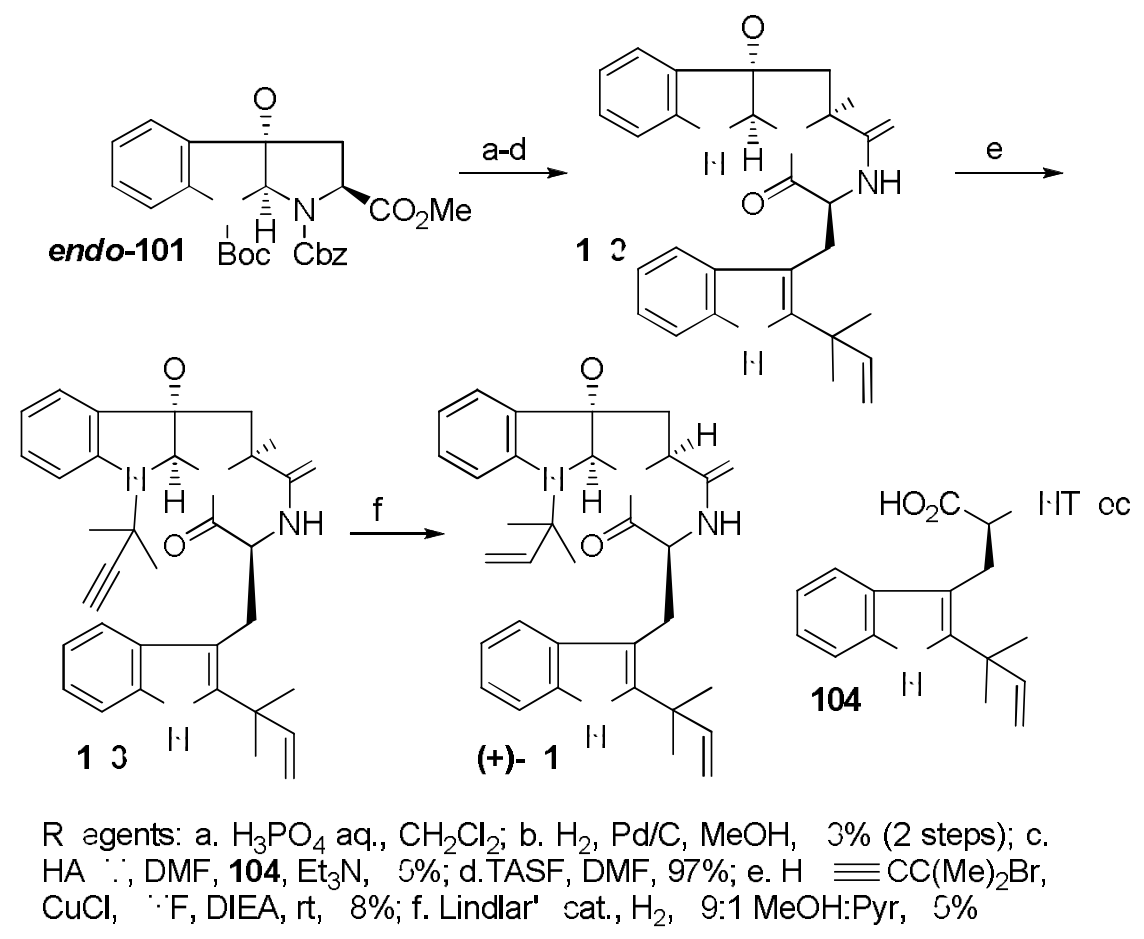

Scheme 11. Total synthesis of $(+)$-okaramine $C(\mathbf{1 1})^{[129]}$

\subsection{Alkylative cyclization}

\subsubsection{Cyclization with electrophiles (A, Figure 5)}

This procedure uses the reactivity of indole nucleous of tryptamine or tryptophan with alkylating agents over the substituted 3-position, followed by in situ capture of the resulting indoline by the protected lateral amine.

Nakagawa and Kawahara described a concise synthesis of desoxyeseroline (108), ${ }^{[130]}$ a precursor of physostigmine (2) (Scheme 12). ${ }^{[131]}$ Their route was based on a Lewis acid-catalyzed alkylative cyclization of 1,3-dimethylindole with $N$-benzyloxycarbonyl (Cbz) protected aziridine to form compound 107, which is readily converted into physostigmine. They tested several Lewis acids, finding $\mathrm{Sc}(\mathrm{OTf})_{3}$ and $\mathrm{TMSCl}$ in dichloromethane to be the best conditions.

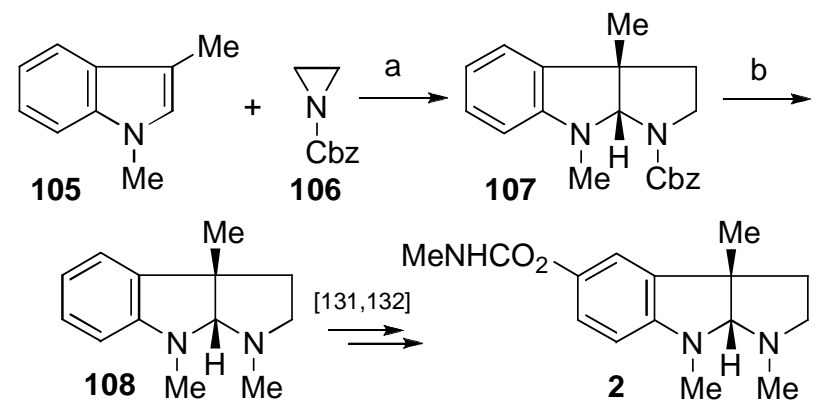

Reagents: a. $\mathrm{Sc}(\mathrm{OTf})_{3}, \mathrm{TMSCl}, \mathrm{CH}_{2} \mathrm{Cl}_{2},-30 \stackrel{\circ}{\circ}, 52 \%$;

b. Red-Al, toluene, reflux, $95 \%$

Scheme 12. Alkylative cyclization of 1,3-dimethylindole ${ }^{[130]}$ 
Reaction of $N_{b}$-protected tryptamine with allyl bromides afforded the $N^{1}$-protected 3a,8-bisallyl$\mathrm{HPI}^{[133]}( \pm)$-debromoflustramides $\mathrm{B}$ and $\mathrm{E}$ and $( \pm)$-debromoflustramines $\mathrm{B}$ and $\mathrm{E}$ have been prepared using this procedure. ${ }^{[134]}$

Nakagawa et al. synthesized ( \pm )-esermethole (112) using an alkylative cyclization. ${ }^{[135]}$ Reaction of Corey-Kim reagent (113) with tryptamine carbamate 109 and $i$ - $\operatorname{rr}_{2} \mathrm{NEt}$ gave the HPI 110 . Simultaneous reductive methylation and desulfurization of $\mathbf{1 1 0}$ were achieved by hydrogenation using Raney $\mathrm{Ni}$ (W2) and aqueous $\mathrm{HCHO}$ to give 111, which was then reduced with Red-Al to give $( \pm)$-112 in quantitative yield (Scheme 13).
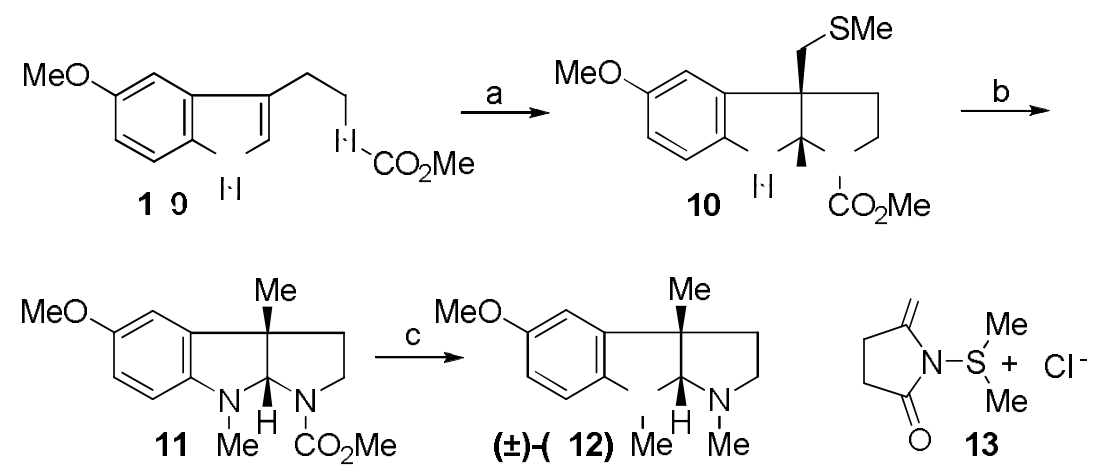

$\mathrm{R}$ egents: a. $13, i-\mathrm{Pr}_{2} \mathrm{NEt},-{ }^{\circ} \mathrm{C}, 8 \% ;$ b. $\mathrm{H}_{2}$, Ni-Raney (W2), aq. $\mathrm{HCHO}, \mathrm{EtOH}$, reflux, $0 \%$; c. Red-Al, toluene, reflux, $96 \%$

Scheme 13. Synthesis of $( \pm)$-esermethole (112) by Nakagawa et al. ${ }^{[135]}$

The Ganesan group published a fast and elegant three-step total synthesis of ( \pm )debromoflustramine B (69) via zinc triflate-mediated biomimetic alkylative cyclization from tryptamine (Scheme 14). ${ }^{[136]}$

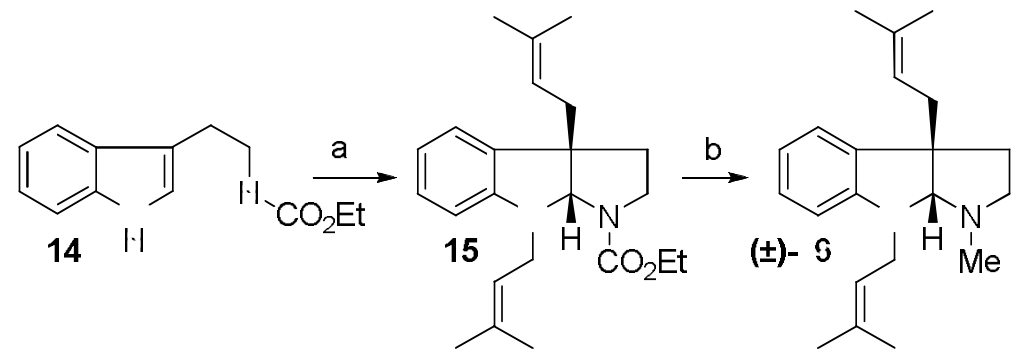

$\mathrm{R}$ egents: a. prenyl bromide (4 equiv), $\mathrm{Zn}(\mathrm{OTf})_{2}, \mathrm{Bu}_{4} \mathrm{NI}, i-\mathrm{Pr}_{2} \mathrm{NEt}$, toluene, $\mathrm{rt}, 70 \%$; b. Red-Al, toluene, reflux, $96 \%$

Scheme 14 . Total synthesis of $( \pm)$-debromoflustramine B (69) by Ganesan et al. ${ }^{[136]}$

(-)-Flustramine B (4) and (-)-debromoflustramine B (69) were enantioselectively synthesized in routes based on organocatalytic preparation of pyrroloindoline (Scheme 32). Addition of tryptamine 116 to $\alpha, \beta$-unsaturated aldehydes in the presence of imidazolidinone catalysts 119 gave the cyclized pyrroloindoline adduct 117 in high yield and with excellent enantioselectivities. Adduct 117 
was transformed into (-)-4 and (-)-69 using common synthetic procedures, in excellent yields and with high ee's. ${ }^{[137]}$

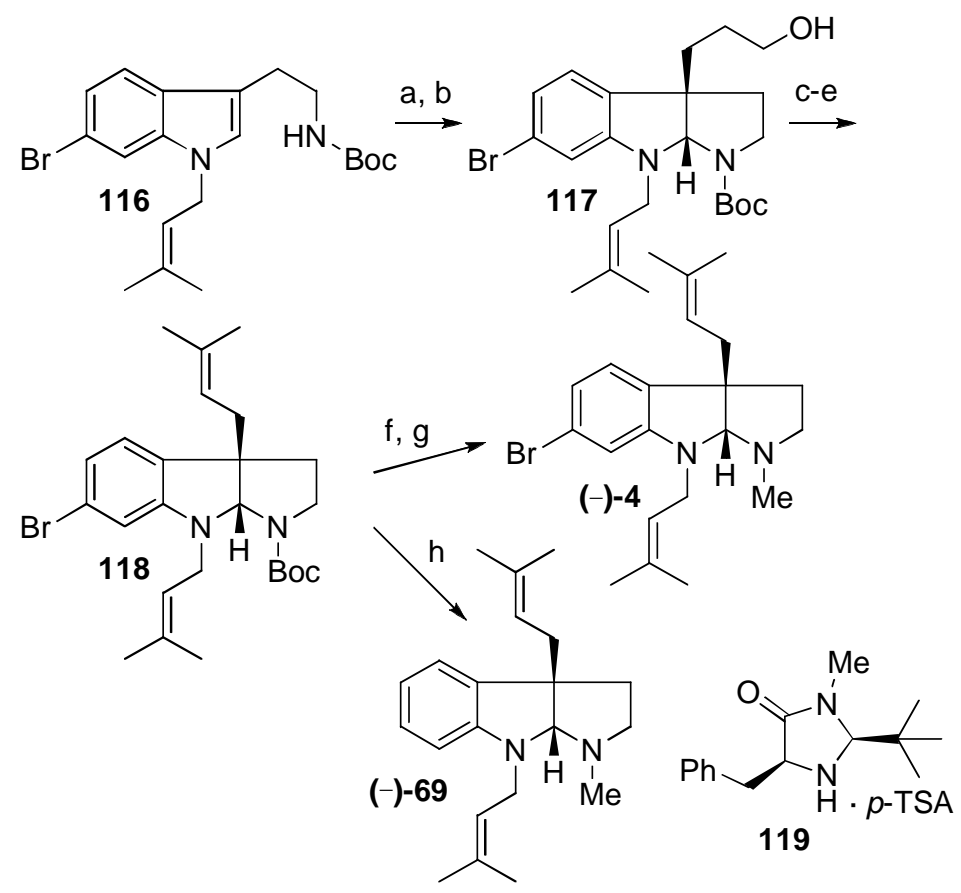

Reagents: a. propenal, 119; b. $\mathrm{NaBH}_{4}, \mathrm{MeOH}, 78 \%, 90 \%$ ee

(2 steps); c. MsCl; d. $\mathrm{NO}_{2} \mathrm{PhSeCN}, \mathrm{H}_{2} \mathrm{O}_{2}, 89 \%$ (2 steps);

e. Grubbs metathesis, 2-methyl-2-butene, $94 \%$; f. TMSI; g.

$\mathrm{NaBH}_{4}, \mathrm{HCHO}, 89 \%$ (2 steps); h. $\mathrm{LiAlH}_{4}, 91 \%$

Scheme 15. Enantioselective syntheses of (-)-flustramine B (4) and (-)-debromoflustramine B $(69)^{[137]}$

A one-pot synthesis of $( \pm)$-deoxypseudophrynaminol ${ }^{[138]}$ was afforded with moderate yield from the commercially available $N^{b}$-methyltryptamine by transformation into the corresponding Grignard reagent, followed by addition of 4-bromo-2-methyl-2-butene, the target in moderate yield.

Similar chemistry was recently exploited to synthesize isoroquefortine $C$ and roquefortine $C .{ }^{[139]}$ A slightly modified version of this strategy recently enabled preparation of isoroquefortine $E$ (122). ${ }^{[140]}$ A Horner-Wadsworth-Emmons reaction was the key step to building the dehydroamino acid 121, which was then underwent DKP formation (Scheme 16).

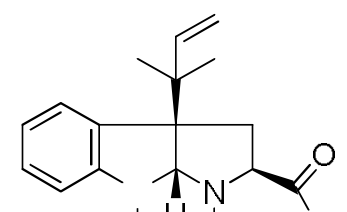

1 2 BoC BoC $\mathrm{MeO}_{2} \mathrm{C} P \mathrm{PO}(\mathrm{r} / \mathrm{l})_{2}$

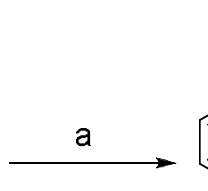

TN 121 Boc Boc<smiles>C=CC(C)(C)C1(C)C[C@H](C(C)=O)NC1(C)C</smiles><smiles>C=CC(C)(C)/C=C\C(/C=C/C(=O)OC)=N/C=C\C(=O)OC</smiles>

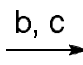

12
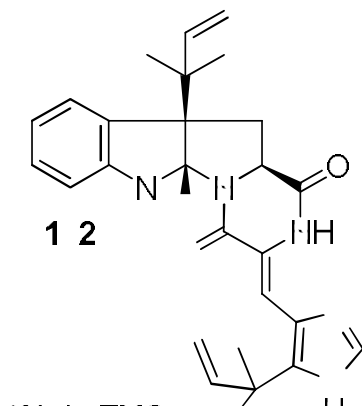

$\mathrm{R}$ agents: a. 5-isoprenyl-1H-imid 2ole-4-carbaldeh :'e, $\mathrm{DBU}, \mathrm{CH}_{2} \mathrm{Cl}_{2}, \quad \% \%$; b. TMS;

Scheme 16. Synthesis of isoroquefortine $E(\mathbf{1 2 2})^{[140]}$ 
(-)-Ardeemin (127) and its $N$-acyl analogs have been synthesized from L-Trp in 20 steps in approximately $2 \%$ overall yield (Scheme 17) ${ }^{[141]}$ One-pot reaction of 123 with the diazoester 128 gave the chiral 3a-substituted HPI 124 containing the proper configuration in three stereocenters. (-)-127 was prepared from the tetracyclic compound 124 via the following steps: transformation of the ethyl acetate substituent into the corresponding isoprenyl group, hydrolysis of the cyclic carbamate, and orthogonal protection of both amino groups to give 125 , which was converted into the DKP 126. Finally, formation of the last benzopyrimidone condensed-ring by acylation with $o$ azidobenzoic anhydride followed by cyclization.

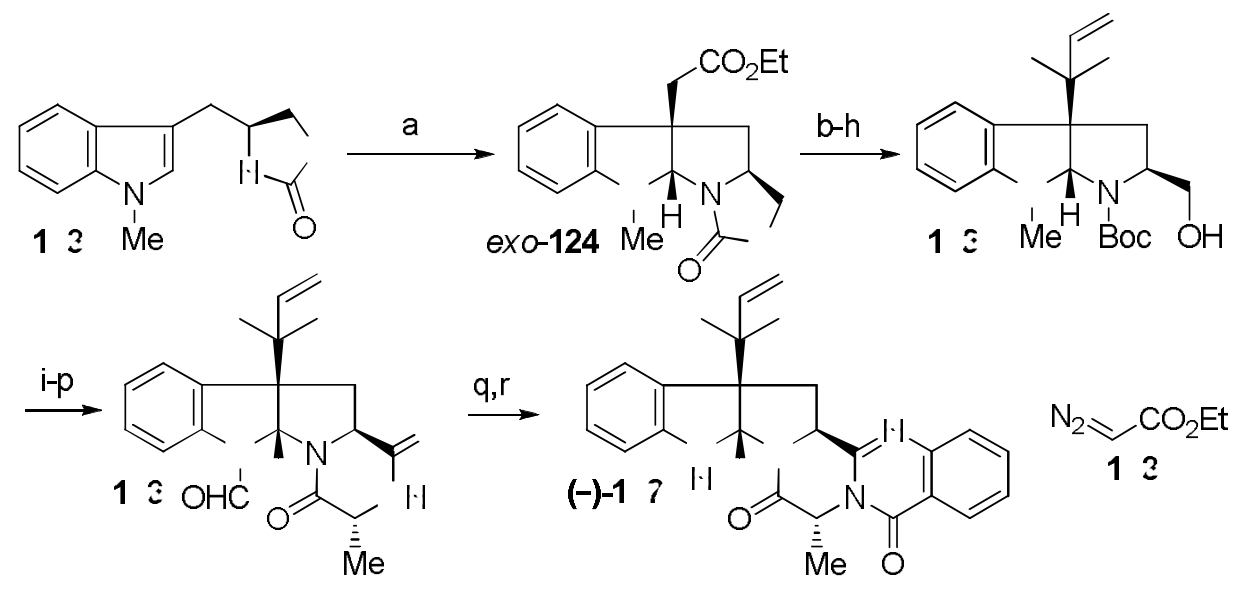

R agents: a. $12, \mathrm{Cu}(\mathrm{OTf})_{2}, \mathrm{CH}_{2} \mathrm{Cl}_{2},-3^{\circ} \mathrm{C}, 82 \%$; b. LDA, Mel, $\because \mathrm{F},-?^{\circ} \mathrm{C}$ to $\mathrm{rt}$, c. LDA, Mel, $\because \mathrm{F},-?{ }^{\circ} \mathrm{C}$ to $\mathrm{rt}, 72 \%$ (2 steps); d. $\mathrm{LiBH}_{4}, \because \mathrm{F}, \mathrm{MeOH}, 0{ }^{\circ} \mathrm{C}, 61 \%$; e. DMP, $\mathrm{CH}_{2} \mathrm{Cl}_{2}$, rt, $92 \%$; f. $\mathrm{Ph}_{3} \mathrm{PMel}$, LHMDS, $\because \mathrm{F}$, - ? ${ }^{\circ} \mathrm{C}$ to rt, $3 \%$; g. Kt-BuO, aq $t-$ BuOH, quant;; h. (Boc) $)_{2} \mathrm{O}, \mathrm{CH}_{2} \mathrm{Cl}_{2}$, it, $5 \%$ i. DMP, $\mathrm{CH}_{2} \mathrm{Cl}_{2}$, rt, $92 \%$; j. P C, $\mathrm{CH}_{2} \mathrm{Cl}_{2}$, rt, $76 \%$; k. NaClO${ }_{2}, \mathrm{NaH}_{2} \mathrm{PO}_{4}$ bu fer, rt, quant. i. $\mathrm{ClCO}_{2} i-\mathrm{Bu}, \mathrm{Et}_{3} \mathrm{~N}$, D-Ala-OMe, $\mathrm{CH}_{2} \mathrm{Cl}_{2}, 0^{\circ} \mathrm{C}, 81 \% ; \mathrm{m}$. TMSI, MeCN, $0^{\circ} \mathrm{C}$, $3 \%$; . LiOH, aq. MeOH, 5\%; o. $\mathrm{ClCO}_{2} j-$ $\mathrm{Bu}, \mathrm{Et}_{3} \mathrm{~N}, \mathrm{CH}_{2} \mathrm{Cl}_{2}, 0{ }^{\circ} \mathrm{C}$ to $\mathrm{rt}, 71 \%$; p. diaster omeric separation; q. $n$-BuLi, ozidoben zic anhydride, $\because \mathrm{F},-{ }^{\circ} \mathrm{C}, 3 \%$; r. $n-\mathrm{Bu}_{3} \mathrm{P}$, ben $\Sigma$ ne, $\mathrm{rt}, 3 \%$

Scheme 17. Total synthesis of $(-)$-ardeemin $(\mathbf{1 2 7})^{[141]}$

Li et al. recently devised an innovative route to aszonalenin (24) and similar alkaloids structure. They employed the enzyme AnaPT, a prenyltransferase, to catalyze the prenylation of $(R)$ benzodiazepinedione $\mathbf{1 2 9}$ in the presence of dimethyl allyl diphosphate (DMAPP) to afford 24 (Scheme 18). ${ }^{[142]}$<smiles>O=C1C(=O)c2ccccc2I=C1Cc1c[nH]c2ccccc12</smiles>

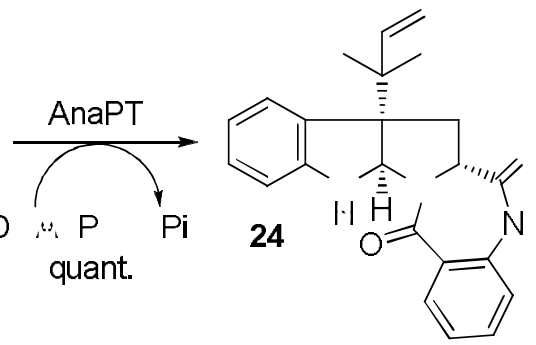

Scheme 18. Enzyme catalyzed synthesis of aszonalenin (24) by Li et al. ${ }^{[142]}$ 


\subsubsection{Cyclization with nucleophiles (B, Figure 5)}

This procedure is based on a Michael addition of a nucleophile on the 3-position of 2hydroxyindolin-3-ylideneacetate followed by in situ lactonization.

The Joseph-Nathan group devised total syntheses of $( \pm)$-flustramines $A(3)$ and $B(4),( \pm)$ flustramides $A(\mathbf{1 3 4})$ and $B(8)$, and $( \pm$ )-debromoflustramines $A$ (135) and $B$ (69) (Scheme 19). ${ }^{[143,144]}$. A conjugate addition of a prenylmagnesium bromide specie to 2-hydroxyindolenines 130 to give the $C^{3}$-epimeric lactone 131 . Decyanation of the resulting $\alpha$-cyano- $\gamma$-lactones with wet alumina in refluxing THF, followed by $N$-deprotection and allylation, gave compounds 133 , which, upon $\mathrm{N}$-methyl insertion under the appropriate conditions, afforded the desired target natural compounds.

Same procedure was used by for the synthesis of dihydroflustramine $C(9)$ and Flustramine . $^{[145]}$<smiles>[Y]c1ccc2c(c1)N(C(C)=O)C(O)C2=C(C#N)COC</smiles>

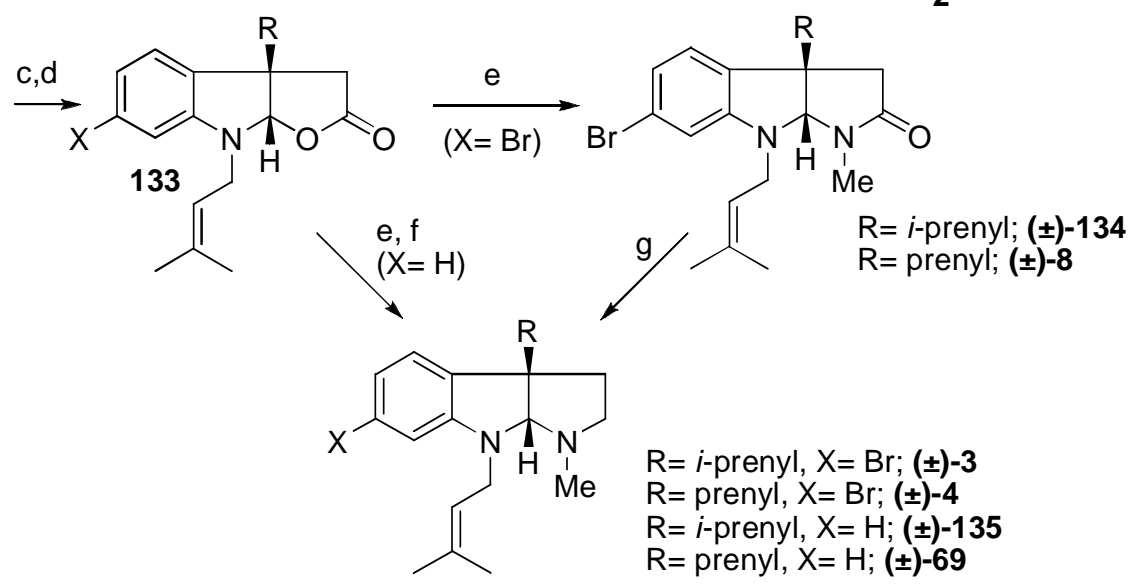

Reagents: a. RMgBr, THF-ether, 30-47\%; b. $\mathrm{Al}_{2} \mathrm{O}_{3}$, THF, $\mathrm{H}_{2} \mathrm{O}$, reflux, 64-95\%; c. MeONa, $\mathrm{MeOH}$, reflux; d. prenyl bromide, $\mathrm{K}_{2} \mathrm{CO}_{3}$ acetone, reflux, $60-70 \%$ (2 steps); e. $\mathrm{MeNH}_{2}$, $\mathrm{MeOH}, 92-98 \%$; f. $\mathrm{LiAlH}_{4}$, THF, reflux, 98\%; g. EtN(Me) $)_{2} \cdot \mathrm{AlH}_{3}, \mathrm{THF}, 96-97 \%$

Scheme 19. Total syntheses of $( \pm)$-flustramines $A(\mathbf{3})$ and $B(\mathbf{4}),( \pm)$-flustramides $A(\mathbf{1 3 4})$ and $B(\mathbf{8})$, and $( \pm)$-debromoflustramines $A(\mathbf{1 3 5})$ and $B(69)^{[144]}$

\subsection{Successive alkylation cyclization of oxoindoles (C, Figure 5)}

Pyrrolidine formation of HPIC from 2-oxoindoles consists in an enolate alkylation followed by $\mathrm{N}^{1}$ $\mathrm{C}^{8 \mathrm{a}}$ reductive bond formation.

Julian and Pilk synthesized $\left( \pm\right.$ )-eserethole $(138),{ }^{[146]}$ based on their previous work on HPI assembly. ${ }^{[147,148]}$ Their approach was actually part of a formal synthesis of physostigmine (2). ${ }^{[149-150]}$ 
The route shown in Scheme 20 comprises $\alpha$-alkylation of the oxoindole 136, followed by reduction of the nitrile, $N$-methylation, and finally, reductive cyclization to give the racemic $( \pm)-\mathbf{1 3 8}$.

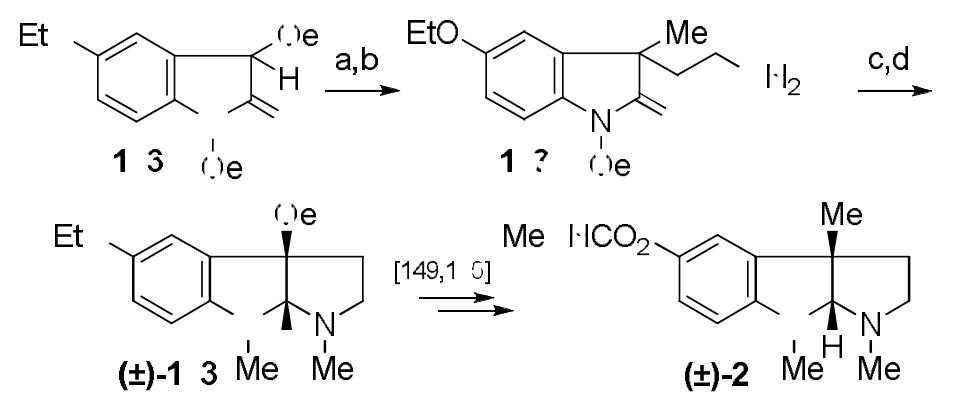

R egents: a. $\mathrm{ClCH}_{2} \mathrm{CN}, \mathrm{NaEtO}$ (or $\mathrm{Na}$ ), $84 \%$; b. $\mathrm{H}_{2}, \mathrm{Pd}, 91 \%$; c. $\mathrm{PhCHO}$, then Mel folowe oy $\mathrm{h}$ :'rolysis, $86 \%$; d. Na, EtOH, $9 \%$

Scheme 20. Synthesis of $( \pm)$-eserethole $(\mathbf{1 3 8})^{[146]}$

The Julian and Pilk procedure has been used extensively to prepare Calabar alkaloids. It has been modified to improve the oxoindole preparation, ${ }^{[151-160]}$ adapted to the use of protecting groups, ${ }^{[161-}$ ${ }^{164]}$ performed with chemical resolution of different intermediates, ${ }^{[163,165-168]}$ and combined with asymmetric alkylation of oxindole. ${ }^{[169,170]}$ Furthermore, a modified Julian and Pilk procedure has been used to prepare numerous analogs of physostigmine (2) and related alkaloids. ${ }^{[166,171-175]} \mathrm{A}$. Bossi reported an interesting version ${ }^{[176]}$ to prepare a 3-aminoethyloxoindole from 5methoxytryptamine.

A total synthesis of (-)-pseudophrynaminol (10) based on diastereoselective $\alpha$-alkylation of the chiral oxoindole 139 with methyl 4-bromo-2-methylbut-2-enoate (Scheme 21) has been reported. ${ }^{[177]}$ The yield and diastereoselectivity of the process strongly depend on the solvent and base used. Separation of the two isomers, followed by reduction of (-)-140 with $\mathrm{LiAlH}_{4}$, gave (-)10. The 1-phenylethylcarbamoyl substituent on the oxoindole nitrogen not only acts as a protecting group, but also as a prochiral group for asymmetric induction in the diastereoselective alkylation, enabling separation of diastereomer (-)-140. Moreover, this group is readily eliminated during reduction of the methyl ester and the carbamate.

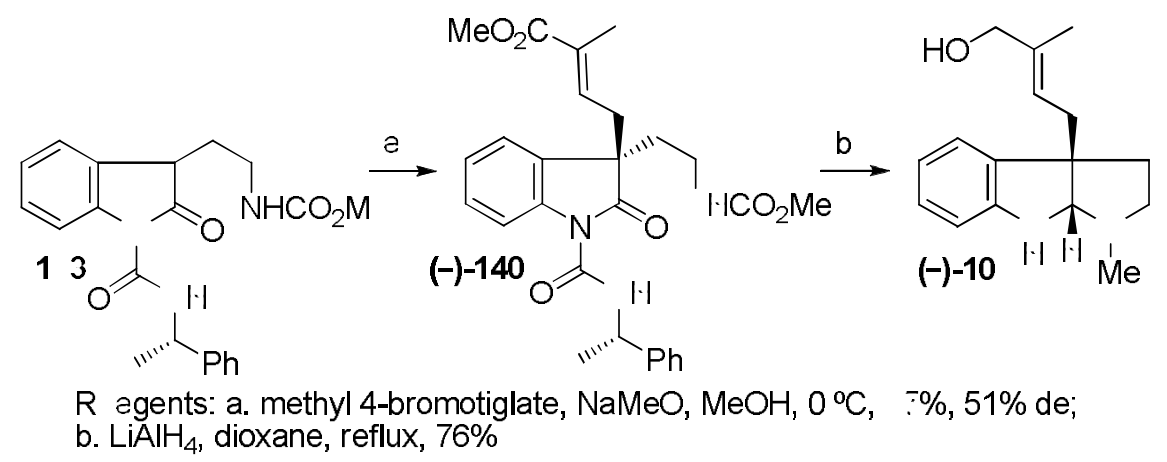

Scheme 21. Total synthesis of (-)-pseudophrynaminol $(\mathbf{1 0})^{[177]}$ 
Identical final ring formation for the Calabar alkaloids (-)-physovenine and (-)-2 was performed using a chiral building block for the diastereocontrolled construction of indoline 142, a precursor of compound 144 (Scheme 22). ${ }^{[132,178]}$ The oxidation level of compound 144 obviates reduction after the cyclization to form the HPI skeleton.

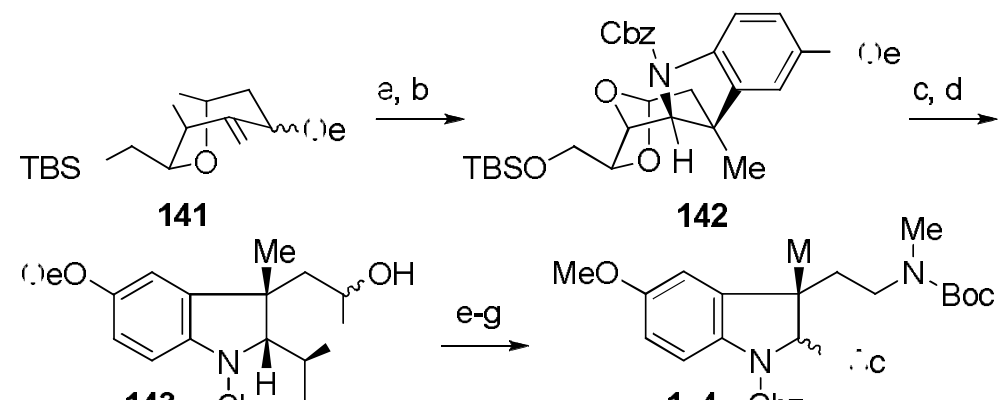

$143 \mathrm{CbZ}$

$14 \mathrm{Cbz}$

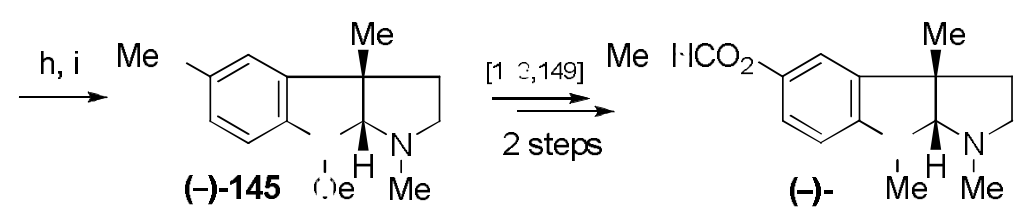

R egents: a. Ar H.l H. 2. $_{2} \mathrm{HCl}, \mathrm{Pyr}-\mathrm{H}_{2} \mathrm{O}(9: 1)$, reflux; b. $\mathrm{LAlH}_{4}, \because \mathrm{F}, \mathrm{O}^{\circ} \mathrm{C}$ then $\mathrm{Cbz}-\mathrm{Cl}$, aq. $\mathrm{K}_{2} \mathrm{CO}_{3}, 70 \%$ (2 steps); c. TBAF, $\because \mathrm{F}$, $3 \%$; d. $\mathrm{Zn}$, $\mathrm{AcOH}-\mathrm{EtOH}(1: 9), 97 \%$; e. $\mathrm{Me} \mathrm{l} \cdot \mathrm{l}_{2} \cdot \mathrm{HCl}, \mathrm{NaBH}_{3} \mathrm{CN}, \mathrm{MeOH}, 0{ }^{\circ} \mathrm{C}, 3 \%$; f. $\mathrm{Boc}_{2} \mathrm{O}, \mathrm{NaHCO}_{3}, \mathrm{MeOH}, 94 \%$; g. $\mathrm{Pb}(\therefore \mathrm{c})_{4}$, ben $\approx$ ene, $60{ }^{\circ} \mathrm{C}$; h. $10 \%$ $\mathrm{HCl}, \mathrm{Et}$.c, reflux, $\mathrm{O} \%(2 \mathrm{steps})$;. $\mathrm{H}_{2}, 10 \% \mathrm{Pd}-\mathrm{C}, 36 \% \mathrm{HCHO}, \mathrm{MeOH}$, $0 \%$

Scheme 22. Synthesis of (-)-physostigmine $(2)^{[132,178]}$

Hayashi employed a similar route oxoindole alkylation in the total synthesis of CPC-1. ${ }^{[179]}$ Overman's group used the same cyclization strategy (D, Figure 5) for an elegant total synthesis of $(-)$-phenserine (150), ${ }^{[180]}$ in which alkylation of compound 146 with the chiral bistriflate 147 was the key step in the preparation of $\mathbf{1 4 9}$, in excellent yield and with more than $99 \%$ ee (Scheme 23 ).
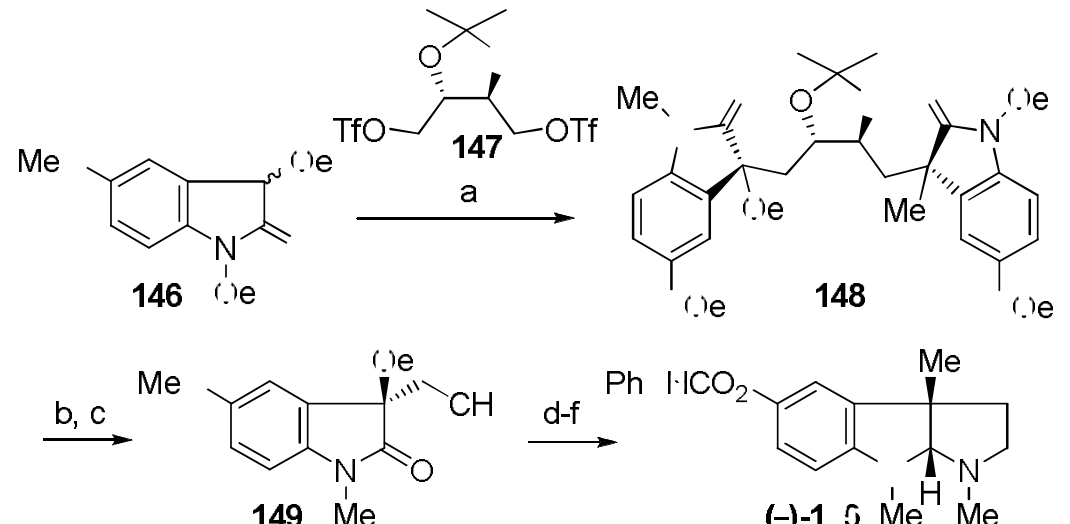

R egents: a. KHMDS, $\because \mathrm{F}-\mathrm{DMPU}(3: 2),-78^{\circ} \mathrm{C}, 70 \%$; b. p-TsOH, $\mathrm{MeOH}, \mathrm{H}_{2} \mathrm{O}$; c. $\mathrm{NalO}_{4}, \because \mathrm{F}, \mathrm{H}_{2} \mathrm{O}, 92 \%$ (2 steps), > $\%$ e; d. Me I. $l_{2} . \mathrm{HCl}, \mathrm{LiAlH}_{4}, \mathrm{MgSO}_{4}, \because \mathrm{F}$, 0\%; e. $\mathrm{Br}_{3}, \mathrm{CH}_{2} \mathrm{Cl}_{2}, 91 \%$; f. $\mathrm{NaH}$, $\mathrm{PhNCO}, \quad \because \mathrm{F}, 82 \%$

Scheme 23. Total synthesis of (-)-phenserine (150) by Overman et al. ${ }^{[180]}$ 
Same last steps (D, Figure 5) were used in an efficient route to either enantiomer of $(-)$ physostigmine 2 , and their respective congeners, is summarized in Scheme $24 .{ }^{[181-183]} \mathrm{It}$ is based on versatile, asymmetric preparation of HPIs having carbon substituents at $C^{3 a}$, starting from Zbutenoic acid 151 and $N$-methyl-p-anisidine 154 . The central step is catalytic asymmetric Heck cyclization of (Z)-2-methyl-2-butenanilide $\mathbf{1 5 5}$ to form oxindole aldehyde (S)-149. The same group later prepared several derivatives with aryl substituents at $\mathrm{C}^{3 \mathrm{a}}$ of the HPI. ${ }^{[184]}$

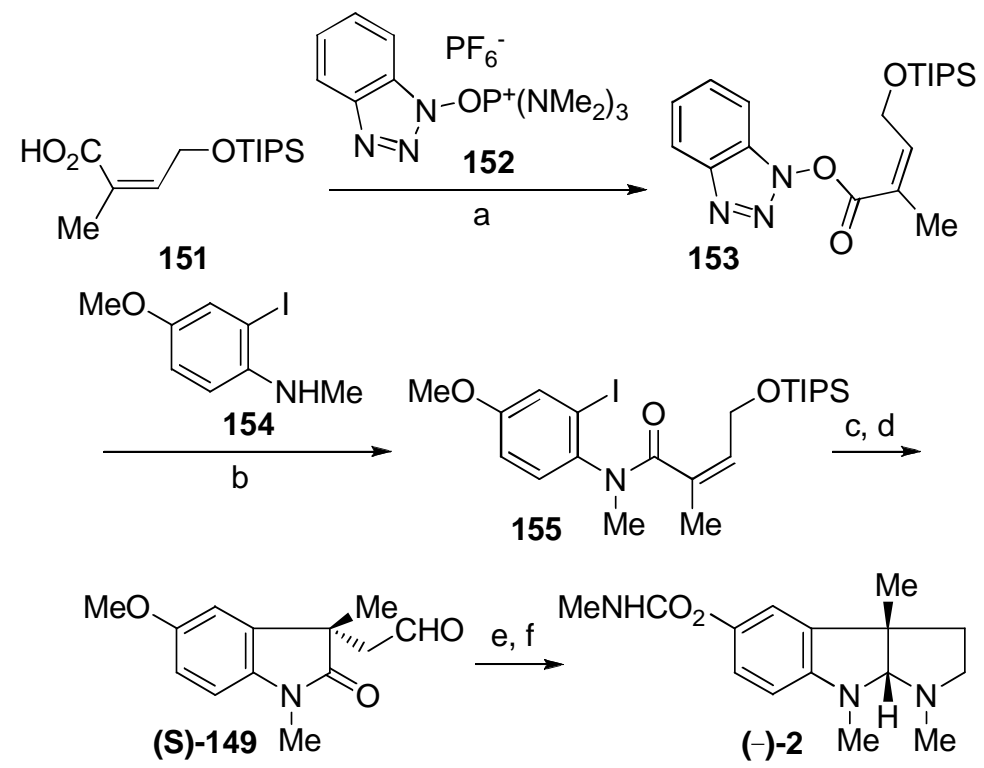

Reagents: a. $\mathrm{Et}_{3} \mathrm{~N}, \mathrm{CH}_{2} \mathrm{Cl}_{2}, 23 \stackrel{\circ}{\circ} \mathrm{C}$; b. $60^{\circ} \mathrm{C}, 67 \%$ (2 steps); c. $10 \%$ $\mathrm{Pd}_{2}(\mathrm{dba})_{3} \cdot \mathrm{CHCl}_{3}, 23 \%(s)$-BINAP, PMP, DMA, $100 \stackrel{\circ}{\circ}$; d. $3 \mathrm{M} \mathrm{HCl}$, $23{ }^{\circ} \mathrm{C}, 84 \%$ (2 steps), 95\% ee; e. $\mathrm{MeNH}_{2} \cdot \mathrm{HCl}, \mathrm{Et}_{3} \mathrm{~N}, \mathrm{LiAlH}_{4}, \mathrm{THF}$, reflux, 88\%; f. $\mathrm{BBr}_{3}, \mathrm{CH}_{2} \mathrm{Cl}_{2}, 23 \stackrel{\circ}{\circ} \mathrm{C}$, then $\mathrm{Na}, \mathrm{Et}_{2} \mathrm{O}, \mathrm{MeNCO}, 63 \%$

Scheme 24. Asymmetric synthesis of (-)-physostigmine (2) ${ }^{[183]}$

Joseph-Nathan synthesized (-)-debromoflustramine B 69 and its enantiomer via the racemic lactone 133 (Scheme 25). Reaction of 133 with (S)-1-phenylethylamine provided the diastereomeric lactams 157 , which were separated, then independently reacted with methylamine and reduced to provide the desired targets. ${ }^{[185]}$ 


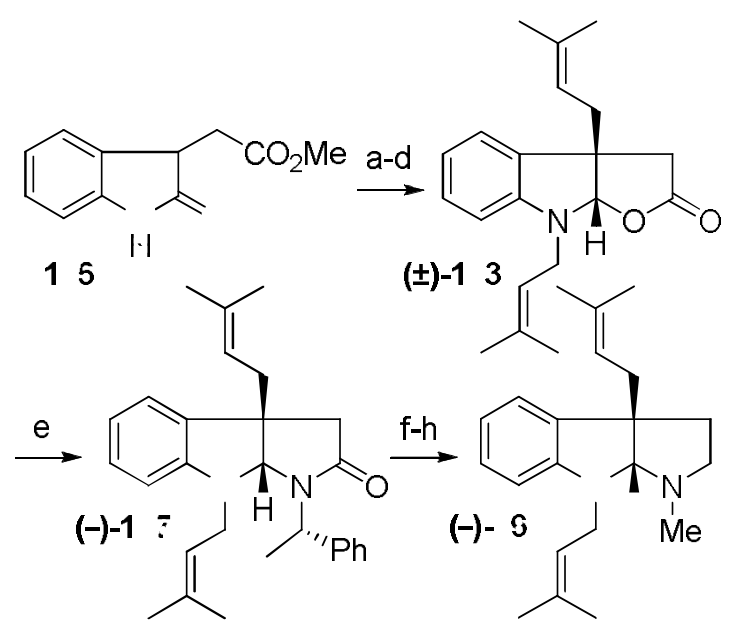

R egents: a. prenyl bromide, $15 \%$ aq. $\mathrm{NaOH}, \mathrm{CH}_{2} \mathrm{Cl}_{2}$ TBA $:-5,-5^{\circ} \mathrm{C}, ? \% ;$ b. $15 \%$ aq. $\mathrm{NaOH}, \mathrm{MeOH}, 40-\mathrm{J}^{2}$ ${ }^{\circ} \mathrm{C}, 87 \%$; c. NaH, $\because \mathrm{F}, \mathrm{rt}$; d. LiBHEt $3, \because \mathrm{F}, 25-3^{\circ} \mathrm{C}$, $\therefore \%$ (2 steps); e. (S)-1-phenylethylamine, $5^{\circ} \mathrm{C}$, then diaster cmeri ceparation, $3 \%$; f. $5 \%$ aq. $\mathrm{AcOH}$, ben zne, s aled tube, $10{ }^{\circ} \mathrm{C}, 3 \% ;$ g. $40 \%$ aq. Me $\mathrm{H} \mathrm{H}_{2}, \mathrm{MeOH}, 3 \%$; h. $\mathrm{LiAlH}_{4}, \because \mathrm{F}, 9 \%$

Scheme 25. Synthesis of (-)-debromoflustramine B $(69)^{[185]}$

Trost described the earliest examples of molybdenum catalyzed enantioselective allylation of prochiral nucleophiles, reported an interesting route to (-)-esermethole (145) based on this chemistry (Scheme 26). ${ }^{[186]}$ Excellent yields and good-to-excellent enantioselectivities were obtained with a large variety of functionalities at the three positions of the starting oxoindole 146, which provided 3-allyloxoindole 159 with $82 \%$ ee. Oxidation of the terminal double bond in 159 and reductive cyclization of the resulting aldehyde with methylamine afforded (-)-145.

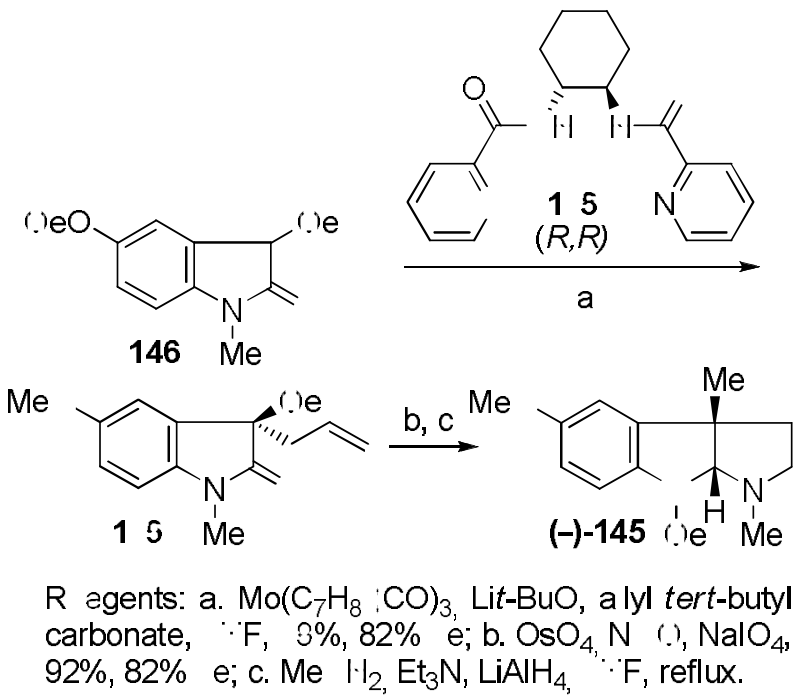

Scheme 26. Synthesis of (-)-esermethole (145) by enantioselective allylation of 2-oxoindole by $\operatorname{Trost}^{[186]}$ 
A total synthesis of (-)-flustramine B (4) starting from the spiro compound 161, enantioselectively prepared via one-pot intramolecular Ullmann coupling and Claisen rearrangement of the iodoindole 160, has been reported (Scheme 27) ${ }^{[187]}$ Compound 161 into 162 was transformed by doublebond oxidation, Wittig reaction and isomerization. $N$-prenylation of the resulting product, and subsequent $\mathrm{N}^{1}-\mathrm{C}^{8 \mathrm{a}}$ bond formation, yielded $(-)-4 .^{[188]}$

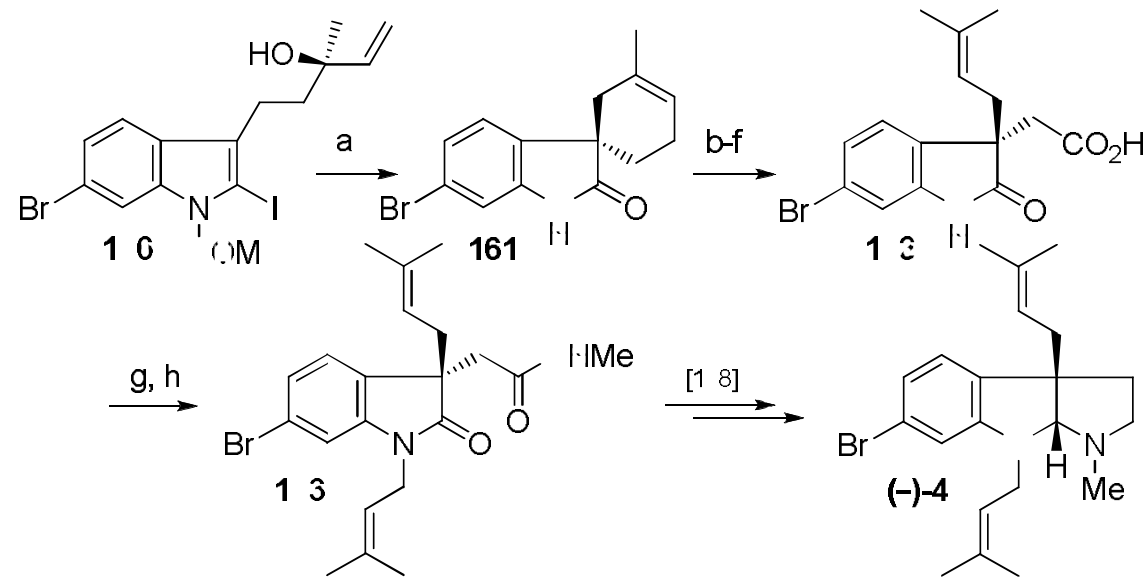

R egents: a. $\mathrm{CuCl}, 2$-amino :ridine, $\mathrm{NaMeO}, \mathrm{MeOH}$, triglyme, $10{ }^{\circ} \mathrm{C}, 69 \%$; b. $\mathrm{OsO}_{4}, \mathrm{~N}$ (-), acetone, $\mathrm{H}_{2} \mathrm{O}$, it; c. $\mathrm{NaIO}_{4}, \because \mathrm{F}, \mathrm{H}_{2} \mathrm{O}$, rt; d. $\mathrm{NaClO}_{2}$, $\mathrm{NaH}_{2} \mathrm{PO}_{4} \cdot 2 \mathrm{H}_{2} \mathrm{O}$, 2-methyl-2-butene, $t$-BuOH, $\mathrm{H}_{2} \mathrm{O}, \because \mathrm{F}$, rt, $84 \%$ (3 steps); e. $\mathrm{Ph}_{3} \mathrm{PMeBr}, n$-BuLi, $\because \mathrm{F},-25^{\circ} \mathrm{C}$ to rt; f. $\mathrm{H}_{2} \mathrm{SO}_{4}$ then $\mathrm{MgSO}_{4}, 1,4$-di ::ane, $60^{\circ} \mathrm{C}$; g. prenyl bromide, $\mathrm{K}_{2} \mathrm{CO}_{3}$, acetone, reflux, $18 \%$ (3 steps); h. aq. $\mathrm{Me} \mathrm{H} \cdot \mathrm{I}_{2}, \mathrm{MeOH}$, $\mathrm{rt}, ? \%$

Scheme 27. Total synthesis of (-)-flustramine B $(4)^{[187]}$

\subsection{Synthesis of HPI system by rearrangements processes}

\subsection{1. [3.3]-Sigmatropic rearrangements (E, F, G, Figure 5)}

Marino et al. showed that 2-(methylsulfinyl)indole reacts with dichloroketene to produce a lactone ${ }^{[189]}$ useful for assembling an HPI core. The same group later established that lactonization of chiral vinyl sulfoxides with dichloroketene occurs with complete control of the relative and absolute configurations. They employed a then new class of sulfoxylating agents, $N$ (alkylsulfinyl)oxazolidinones, to prepare the starting chiral indolyl sulfoxide. They reported that the size of the alkyl group on the sulfoxide positively correlates with the degree of asymmetric induction. ${ }^{[190]}$ Lactonization of isopropyl indolyl sulfoxide 164, followed by desulfonylation and dechlorination, gave 165 (in good enantiomeric excess), which was then transformed into (-)-2 (Scheme 28). 
$\mathrm{Bn}$

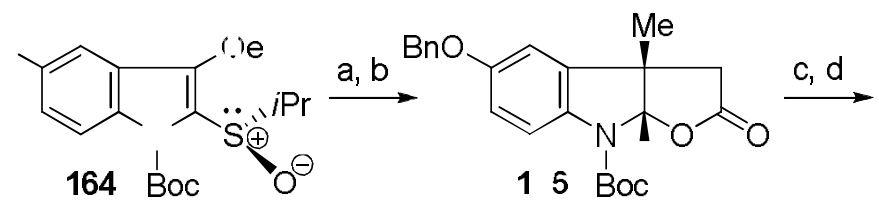

$\mathrm{Bn}$

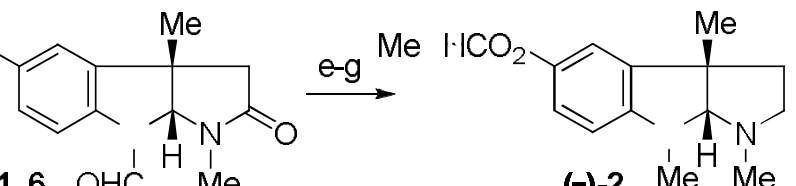

R egents: a. $\mathrm{Zn} / \mathrm{CuCl}, \mathrm{Cl}_{3} \mathrm{COCl}, \because \mathrm{F}, 0^{\circ} \mathrm{C} ;$ b. $n-\mathrm{Bu}_{3} \mathrm{SnH}$, AlBN, toluene, reflux, $37 \%$ (2 steps), $70-75 \%$ e; c. $\mathrm{HCO}_{2} \mathrm{H}$, then $\mathrm{MeCO}_{2} \mathrm{CHO}, 94 \%$; d. Me $\mathrm{H}_{2},-3^{\circ} \mathrm{C}$ to $\mathrm{rt}$, then $\mathrm{H}_{2} \mathrm{SO}_{4}$ cat, DMF, $15^{\circ} \mathrm{C}, 68 \%$; e. $\mathrm{BH}_{3} . \quad \because \mathrm{F}, 0^{\circ} \mathrm{C}$ to reflux, $; \%$; f. Ni-Raney

(W2), $\because F$, reflux; g. Na cat., MeNCO, 60\% (2 steps)

Scheme 28. Enantioselective synthesis of (-)-physostigmine $(2)^{[190]}$

A close procedure (E, Figure 5$)$ was developed by Padwa for the synthesis of $( \pm)$-desoxyeseroline (108) using an efficient route to highly functionalized $\gamma$-lactams (Scheme 29). ${ }^{[191]}$ This route comprised reaction of the indolyl sulfylimine 167 with the highly electrophilic dichloroketene to generate a zwitterionic intermediate. Subsequent [3,3]-sigmatropic rearrangement, followed by intramolecular trapping of the Pummerer cation by the amido anion, furnished the $\gamma$-lactam product 169 in good yield. Reduction of this compound with $\mathrm{Zn}$ and $\mathrm{AcOH}$, followed by treatment with $\mathrm{HCO}_{2} \mathrm{H}$, provided 170. Removal of the $\mathrm{N}$-tosyl group, followed by $\mathrm{N}$-methylation and subsequent reduction of the lactam and the formamide, afforded $( \pm)-108$ in good total yield.

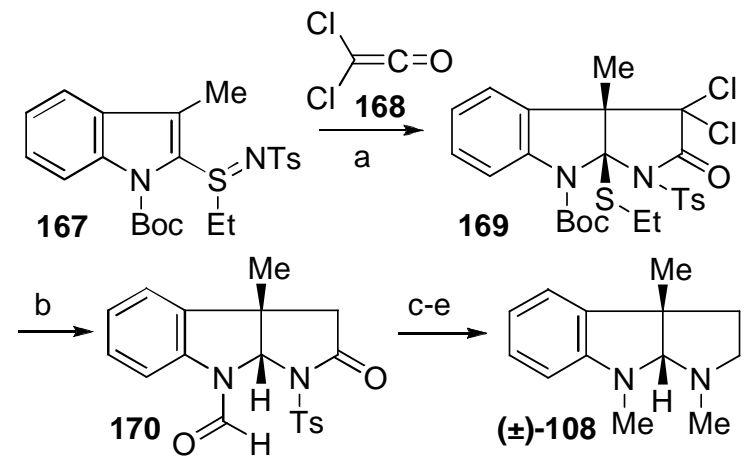

Reagents: a. $\mathrm{Zn}-\mathrm{Cu}, \mathrm{THF}, \mathrm{Cl}_{3} \mathrm{CCOCl}, 78 \%$; b. $\mathrm{Zn}$, $\mathrm{AcOH}$, TMEDA, EtOH, then $\mathrm{HCO}_{2} \mathrm{H}, 72 \%$; c. $\mathrm{Na}$, naphthalene, THF, $81 \%$; d. Mel, NaH, THF, 87\%; e. $\mathrm{BH}_{3} \cdot \mathrm{THF}, \mathrm{THF}, 80 \%$

Scheme 29. Synthesis of $( \pm)$-desoxyeseroline $(\mathbf{1 0 8})^{[191]}$

A formal synthesis of ( \pm )-physostigmine (2) via 3,3-rearrangement of a bis-enamine was described by Lobo, Prabhakar et al. ${ }^{[192,193]}$

( \pm )-Desoxyeseroline (108) was obtained via [3,3]-sigmatropic rearrangement of the $N$ methylvinylamino skeleton of 171 (F, Figure 5). Thermolysis of the enaminoester 171 in $0^{-}$ 
dichlorobenzene gave the tricyclic compound 172 in excellent yield. Compound 172 was easily transformed into the carbamate 173 by a two-step sequence of $N$-methoxycarbonylation and catalytic hydrogenation. The best conditions they found for removing the carboxylic ester at $C^{3}$ comprised irradiation of the benzophenone oxime ester 174 in a THF-i-PrOH mixture containing a large excess of tert-butylthiol (Scheme 30 ).<smiles></smiles>

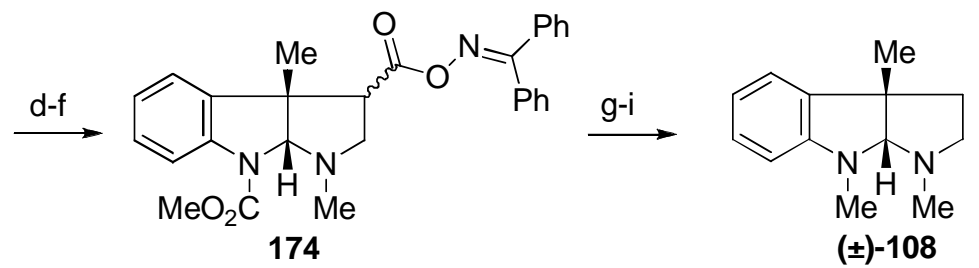

Reagents: a. o- $\mathrm{Cl}_{2} \mathrm{C}_{6} \mathrm{H}_{4}$, reflux, $91 \%$; b. $\mathrm{ClCO}_{2} \mathrm{Me}$, DMAP, $\mathrm{Et}_{2} \mathrm{O}, 0 \stackrel{\circ}{ } \mathrm{C}$ to rt, $81 \%$; c. $\mathrm{H}_{2}, \mathrm{PtO}_{2}, \mathrm{MeOH}, 45 \mathrm{psi}, 93 \%$; d. aq. $\mathrm{NaOH}, \mathrm{MeOH}$, reflux; e. $\mathrm{ClCO}_{2} i-\mathrm{Bu}, \mathrm{THF}$, $-20 \stackrel{\circ}{-}$; f. $\mathrm{Ph}_{2} \mathrm{C}=\mathrm{NOH}, \mathrm{Et}_{3} \mathrm{~N}, 75 \%$ (3 steps); g. hv, $i-\mathrm{PrOH}, \mathrm{THF}, t-\mathrm{BuSH}, 92 \%$; h. $\mathrm{LiAlH}_{4}, \mathrm{THF}$, reflux, $69 \%$; i. aq. $\mathrm{HCHO}, \mathrm{NaBH}_{3} \mathrm{CN}, 67 \%$

Scheme 30. Synthesis of $( \pm)$-desoxyeseroline (108) via [3,3]-sigmatropic rearrangement ${ }^{[193]}$

There is a utile route to 3-allyl-3-cyanomethylindolin-2-ones which is also amenable to prepare structurally diverse libraries of 3a-allyl-HPI that is based on domino reactions of 2-allyloxyindolin-3ones of the type 175 (Scheme 31). ${ }^{[194,195]}$ The process comprises olefination, isomerization, Claisen rearrangement, and deacetylation to give 3-allyl-3-cyanomethylindolin-2-ones of the type 178. Reductive cyclization enabled preparation of 3a-allyl-HPI-containing alkaloids (G, Figure 5).

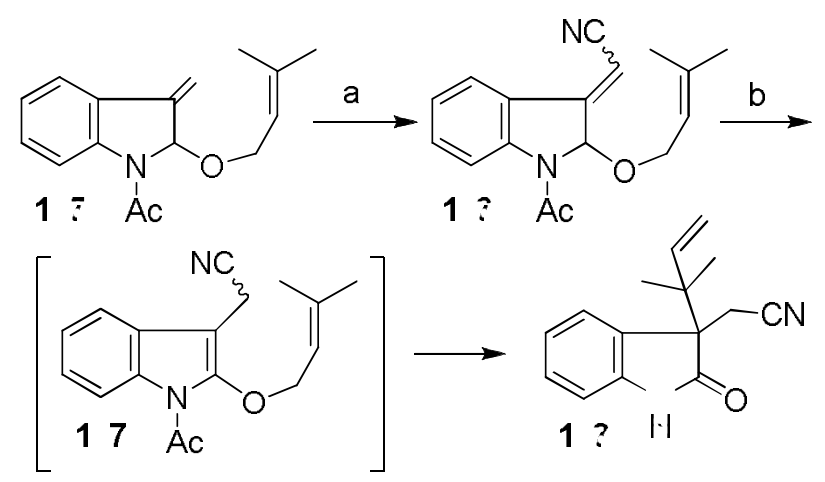

$\mathrm{R}$ agents: a. $\mathrm{Ph}_{3} \mathrm{P}=\mathrm{CHCN}$, toluene, reflux, $70 \%$; b. $\mathrm{DBU}$, $0^{\circ} \mathrm{C}, ? \%$

Scheme 31. Synthesis of 3-allyl-3-cyanomethylindolin-2-one $178^{[195]}$

$( \pm)$-Flustramines $A(3)$ and $C,( \pm)$-flustramide $A$, and $(+)-$ and $(-)$-debromoflustramine $A$ were ultimately obtained by this route. ${ }^{[196]}$ 
While studying nucleophilic substitution in indoles, the Somei group reacted $N$-methoxyindole derivatives with alkoxides to obtain useful route for the synthesis of ( \pm )-debromoflustramine $B$ (69). ${ }^{[197]}$ Further studies of the same authors conducted to the synthesis of 3a-oxygenated $\mathrm{HPIC}^{[198,199]}$ by a rearrangement of the 1-benzoyloxy group of tryptamine $\mathbf{1 7 9}$ followed by cyclization to give the tricyclic system 181 (F, Figure 5). The stereoselectivity of the process was demonstrated by heating (-)-182 in refluxing DMF to produce (-)-183 as the sole product. (Scheme 32)

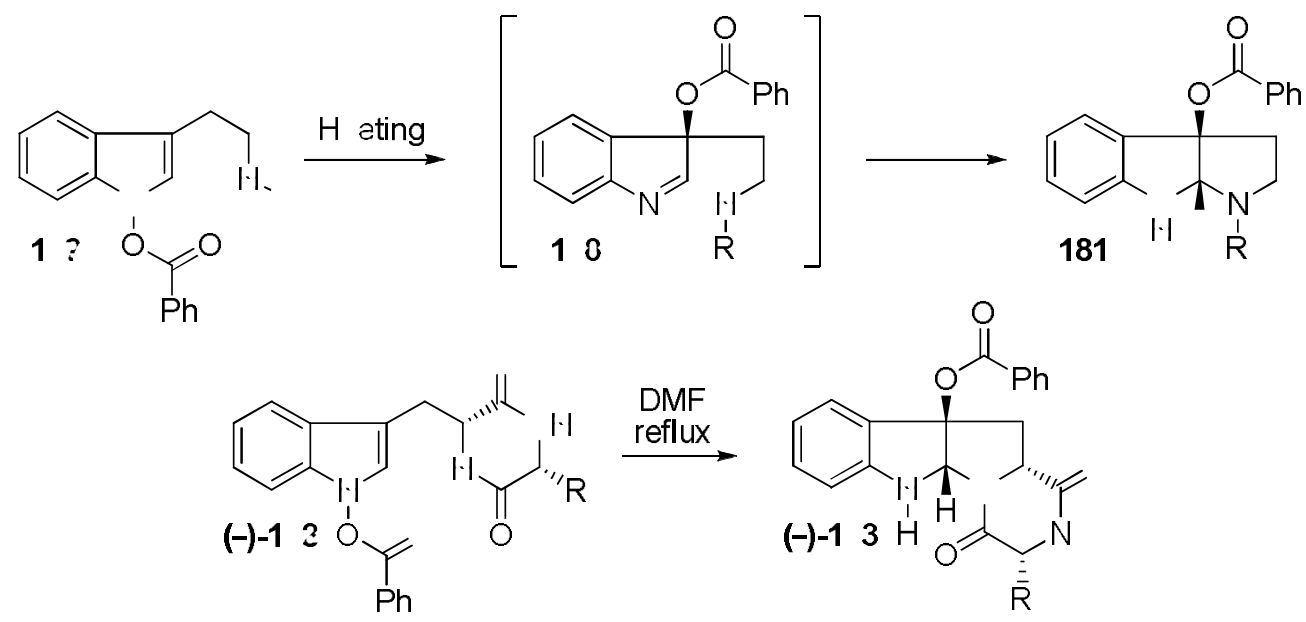

Scheme 32. Somei's synthesis of 3a-oxygenated HPI 183 ${ }^{[198]}$

\subsection{2. [1.2]-Rearrangements}

( \pm )-Flustramine C (185) was synthesized in five steps starting from $N^{b}$-methyltryptamine. The key step was biomimetic oxidation of the natural product deformylflustrabromine (184), causing selective [1.2]-rearrangement of the inverse isoprenyl group and simultaneous cyclization (Scheme 33). ${ }^{[200]}$

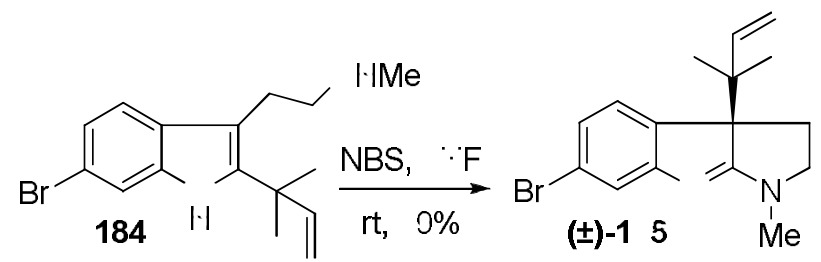

Scheme 33. Synthesis of flustramine $C(\mathbf{1 8 5})^{[200]}$

\subsection{Formation of HPI by elaboration of indole heterocyclic ring}

3.6.1 Reductive cyclization ( $\mathrm{H}$, Figure 5)

A formal total synthesis of (-)-physostigmine 2 was accomplished from the chiral nitro olefin 186 (Scheme 34) and stereochemistry of the product was confirmed. ${ }^{[131]}$ Aromatization of cyclohexene, reduction of the nitro group, and subsequent aniline protection gave 187, which was submitted to 
reductive cyclization. Bromination of the aromatic ring, followed by copper-catalyzed methoxybromine exchange afforded (-)-esermethole (112), which was later converted to (-)-physostigmine. This work constituted the first total synthesis of $(-)-2 .{ }^{[132]}$<smiles>CN1CCC(C)(C2=C([N+](=O)[O-])CCCC2)C1=O</smiles>

16<smiles>CC1CCC(C)(c2ccccc2I)C1=O</smiles>

$1 ? \mathrm{CO}_{2} \mathrm{Et}$

$\mathrm{Me}$

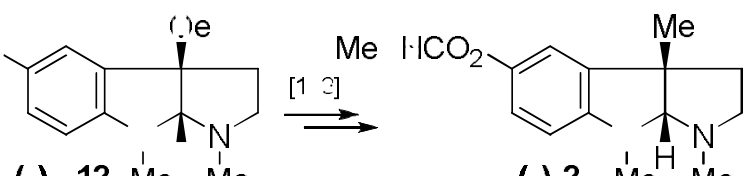

(-)- 12 Me Me

$(-)-2 \mathrm{Me}^{\mathrm{H}} \mathrm{Me}$

$\mathrm{R}$ egents: a. $\mathrm{Br}_{2} \mathrm{Kt}-\mathrm{BuO}, 3 \%$; b. Kt-BuO, DMSO; c. $\mathrm{H}_{2}$, $\mathrm{PtO}_{2}$; d. $\mathrm{ClCO}_{2} \mathrm{Et}, 29 \%$ (3 steps); e. $\mathrm{LiAlH}_{4}$; f. NBS, $5 \%$ (2 steps); g. $\mathrm{NaMeO} / \mathrm{Cul}, 3 \%$

Scheme 34. Synthesis of (-)-esermethole (112) ${ }^{[131]}$

(-)-Physovenine and (-)-2 were enantioselectively synthesized from the optically active enone 188, which was first transformed into the enone 190 via Fischer indolization and retro Diels Alder chemistries. $^{[201]}$ Oxidation of 190 to the lactam 192, followed by reductive cyclization, gave (-)esermethole (112) (Scheme 35). The product was subsequently transformed into (-)physostigmine via (-)-eseroline in two steps as had previously been described. ${ }^{[132]}$ The Takano group used the same route to assemble the non-naturally occurring $(+)-2 .{ }^{[202]}$

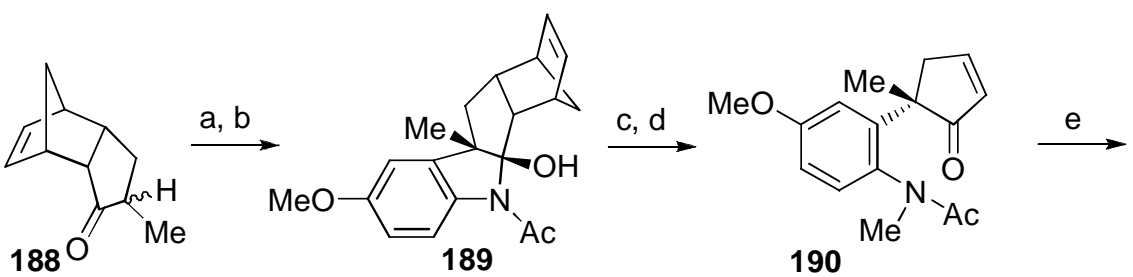<smiles>COc1ccc(N(C)C(C)(C)C)c(N(C)C(C)(C)C)c1N(C)C(C)(C)C</smiles>

Reagents: a. $p-\mathrm{MeOC}_{6} \mathrm{H}_{4} \mathrm{NHNH}_{2}$. $\mathrm{HCl}$, aq. Pyr (1:10), reflux, 82\%; b. $\mathrm{Ac}_{2} \mathrm{O}$, Pyr; c. $\mathrm{NaH}, \mathrm{Mel}, \mathrm{DMF}-\mathrm{THF}(1: 1), 86 \%$ (2 steps); d. o- $\mathrm{Cl}_{2} \mathrm{C}_{6} \mathrm{H}_{4}$, reflux, $66 \%$; e. $\mathrm{O}_{3}$, $\mathrm{MeOH}$, then $\mathrm{NaBH}_{4},-78 \stackrel{\circ}{\circ} \mathrm{C}$ to rt, $10 \% \mathrm{HCl}$ then $\mathrm{NalO}_{4}, 62 \% ;$ f. $\mathrm{Ag}_{2} \mathrm{CO}_{3}$ on celite, benzene, reflux, $88 \%$; g. $40 \%$ aq. $\mathrm{MeNH}_{2}$, sealed tube, $180^{\circ} \mathrm{C}, 76 \%$; h. $i$ - $\mathrm{Bu}_{2} \mathrm{AlH}$, $\mathrm{CH}_{2} \mathrm{Cl}_{2},-78 \stackrel{\circ}{\circ}$, then $\mathrm{NH}_{4} \mathrm{OH}$; i. LiAlH 4 , THF, reflux, $34 \%$ (2 steps)

Scheme 35. Enantiocontrolled total syntheses of (-)-ersemethole (112 $)^{[201]}$

An efficient formal total synthesis of $( \pm$ )-physostigmine (2) in which a new Vicarious nucleophilic substitution reaction between $p$-nitroanisole and a $C$-silylated derivative of $N$-methylpyrrolidinone was exploited to give $195 .^{[203]} \alpha$-Methylation and reductive cyclization of 195 provided the key 
intermediate $N$-demethylesermethole (197) in high yield, which was transformed into the $( \pm)$-2 as had previously been described (Scheme 36$).{ }^{[132]}$

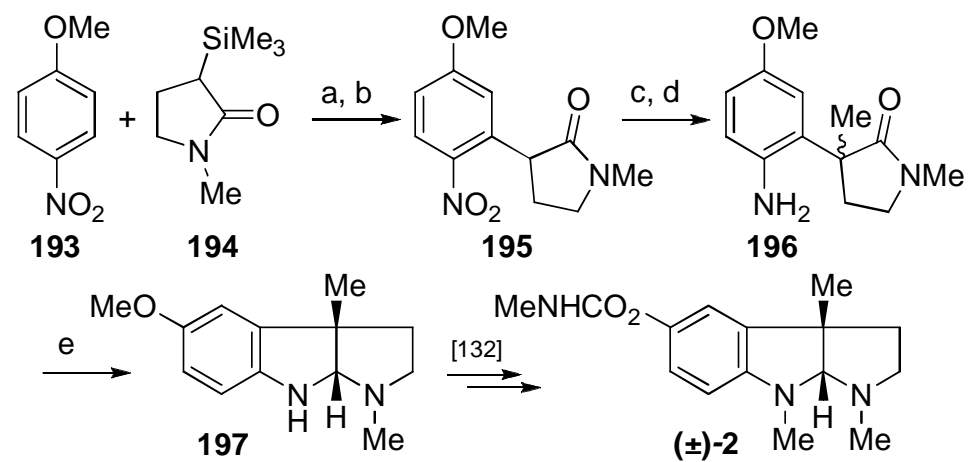

Reagents: a. TASF, THF, $-78 \stackrel{\circ}{\circ}$ to rt; b. DDQ, $85 \%$ (2 steps); c. Mel, $\mathrm{CsOH} \cdot \mathrm{H}_{2} \mathrm{O}, \mathrm{CH}_{3} \mathrm{Ph}, \mathrm{TBAB}$, rt, 94\%; d. $\mathrm{H}_{2}, 10 \% \mathrm{Pd} / \mathrm{C}$, EtOAc, 50 psi, quant. e. $\mathrm{LiAlH}_{4}$, THF, $60 \%$

Scheme 36 . Formal total synthesis of $( \pm)$-physostigmine $(2)^{[203]}$

\subsubsection{Fischer Indole Synthesis (I, Figure 5)}

An efficient method of preparation of HPI system involves the condensation of hydrazines with latent aldehydes to deliver indoline-containing products (Scheme 37) following an interrupted Fischer indolization sequence. ${ }^{[204]}$ This approach amenable to complex targets was applied with good to excellent yields to several examples.

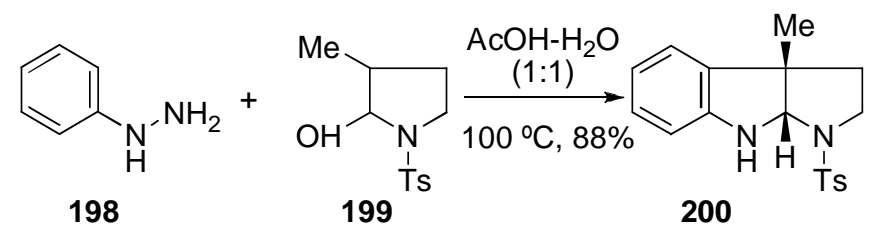

Scheme 37. Preparation of HPI by Fischer indolization ${ }^{[204]}$

A chiral synthetic route to both enantiomers of esermethole (112) was established starting from (S)-O-benzylglycidol (201), ${ }^{[205]}$ which provided a diastereomeric mixture of hemiacetals 203 in excellent yield (Scheme 38). Fischer indolization of 203 with 4-methoxyphenylhydrazine hydrochloride, followed by dimethylation, gave the HPI derivatives 204 and 205, which were readily separated. Compounds 204 and 205 were transformed into (+)-112 and (-)-112, respectively, via the following sequence: O-debenzylation under Birch conditions; removal of the hydroxymethyl group by Swern oxidation of the alcohol; transformation of the resulting aldehyde into a cyanide; and finally, reductive elimination of cyanide from the formed $\alpha$-aminonitrile. 


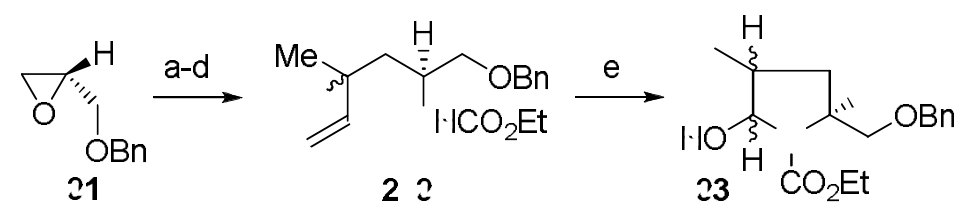

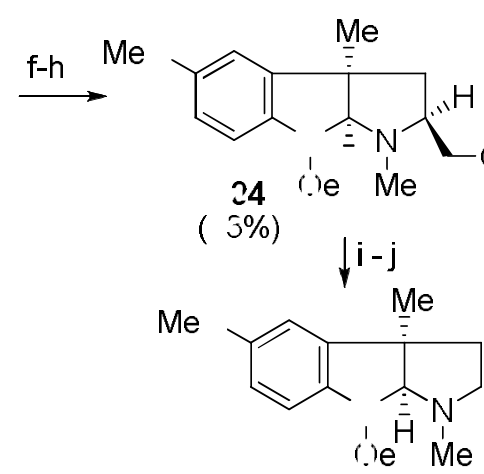

(+)- 1

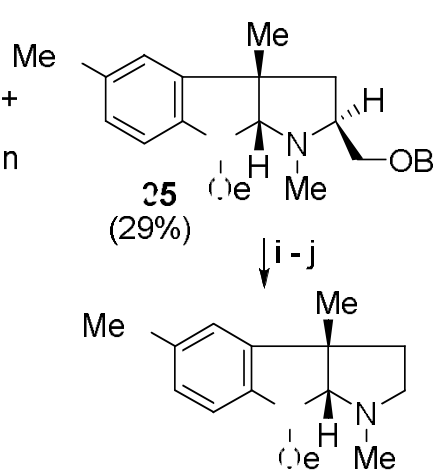

$(-)-12$

R egents: a. $\mathrm{MeCH}=\mathrm{CHCH}_{2} \mathrm{MgCl}, \because \mathrm{F}, 0{ }^{\circ} \mathrm{C}, 0 \%$; b. phta imide,

$\mathrm{Ph}_{3}$, DIAD; c. $\quad \cdot l_{2} \quad \mathrm{H}_{2} \cdot \mathrm{H}_{2} \mathrm{O}$, EtOH, reflux; d. $\mathrm{ClCO}_{2} \mathrm{Et}, \mathrm{Et}_{3} \mathrm{~N}$, $\mathrm{CH}_{2} \mathrm{Cl}_{2}, \quad=\%$ (3 steps); e. $2 \% \mathrm{~mol} \mathrm{OsO}_{4}, \mathrm{NalO}_{4}, \because \mathrm{F}-\mathrm{H}_{2} \mathrm{O}(2: 1)$, then $\mathrm{NalO}_{4}, \because \mathrm{F}, \mathrm{H}_{2} \mathrm{O}, 94 \%$; f. p- $-\mathrm{MeOC}_{6} \mathrm{H}_{4}$ I. I $\mathrm{H} \cdot \mathrm{l}_{2} \cdot \mathrm{HCl}$, Pyr, reflux, 5\%; g. $3 \% \mathrm{HCHO}, \mathrm{NaBH}_{3} \mathrm{CN}, \mathrm{MeOH} ;$ h. $\mathrm{LiAlH}_{4}, \quad$ F, reflux ;. $\mathrm{Na}$ iq. I. $\left.\right|_{3}, 92 \%$-quant.; j. $(\mathrm{COCl})_{2}$, DMSO, $\mathrm{Et}_{3} \mathrm{~N}, \mathrm{CH}_{2} \mathrm{Cl}_{2}$, then $\mathrm{h}: \mathrm{r}$ ::ylamine-O-sulfonic acid, then $\mathrm{NaBH}_{4}, \mathrm{EtOH}$, reflux, 2-25\%

Scheme 38. Synthesis of $(+)$ - and (-)-esermethole (112) ${ }^{[205]}$

Nishida et al. devised an efficient formal synthesis of physostigmine (2) whose key step is a modified Fischer indole synthesis using $N$-methyl- $N$-( $p$-methoxyphenyl)hydrazine and the aldehyde 207 (Scheme 39). ${ }^{[206]}$ Transformation of 111 into 2 had been previously described. ${ }^{[135]}$ The authors later made this chemistry enantioselective by using chiral hydrazines, which they readily prepared from commercially available chiral amines. ${ }^{[207]}$

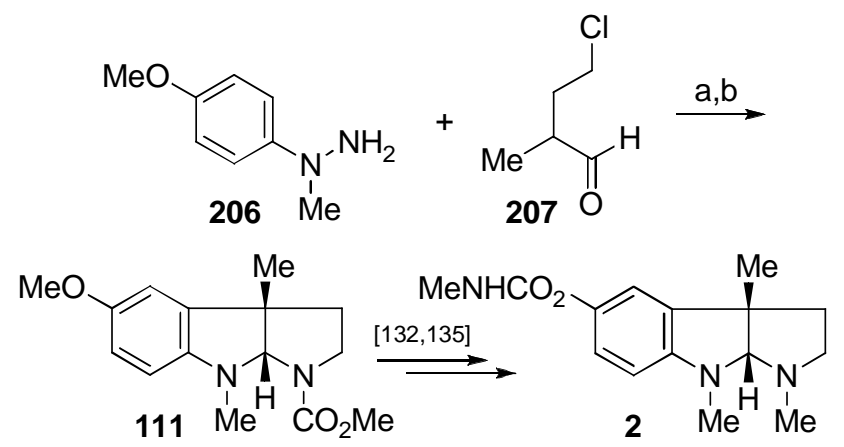

Reagents: a. MeOH, reflux; b. $\mathrm{ClCO}_{2} \mathrm{Me}, \mathrm{Na}_{2} \mathrm{CO}_{3}, \mathrm{CH}_{2} \mathrm{Cl}_{2}$, $\mathrm{H}_{2} \mathrm{O}, 0 \stackrel{\circ}{\circ} \mathrm{C}$ to rt, $80 \%$ (2 steps)

Scheme 39. Synthesis of HPI by modified Fischer indole synthesis ${ }^{[206]}$

3.7. Synthesis of HPI by simultaneous formation of $N^{1}-C^{8 a}$ and $N^{8}-C^{8 a}$ bonds (J, Figure 5) 
Kulkarni et al. recently reported a novel total synthesis of $( \pm)-2$ (Scheme 40$){ }^{[208]}$ Wittig olefination and posterior Claisen rearrangement of $o$-nitroacetophenone afforded the aldehyde 209. Protection of the formyl group, oxidation of the double bond, and reduction of the aldehyde in the resulting intermediate afforded the cyclic acetal 210. Functional group transformation of 210 gave the diamine 211, whose acetal was hydrolyzed with $p$-TSA to furnish the HPI 212. Finally, bis- $N$ methylation of $\mathbf{2 1 2}$ and introduction of carbamate on position 5 following a literature protocol ${ }^{[131]}$ yielded $( \pm)-2$
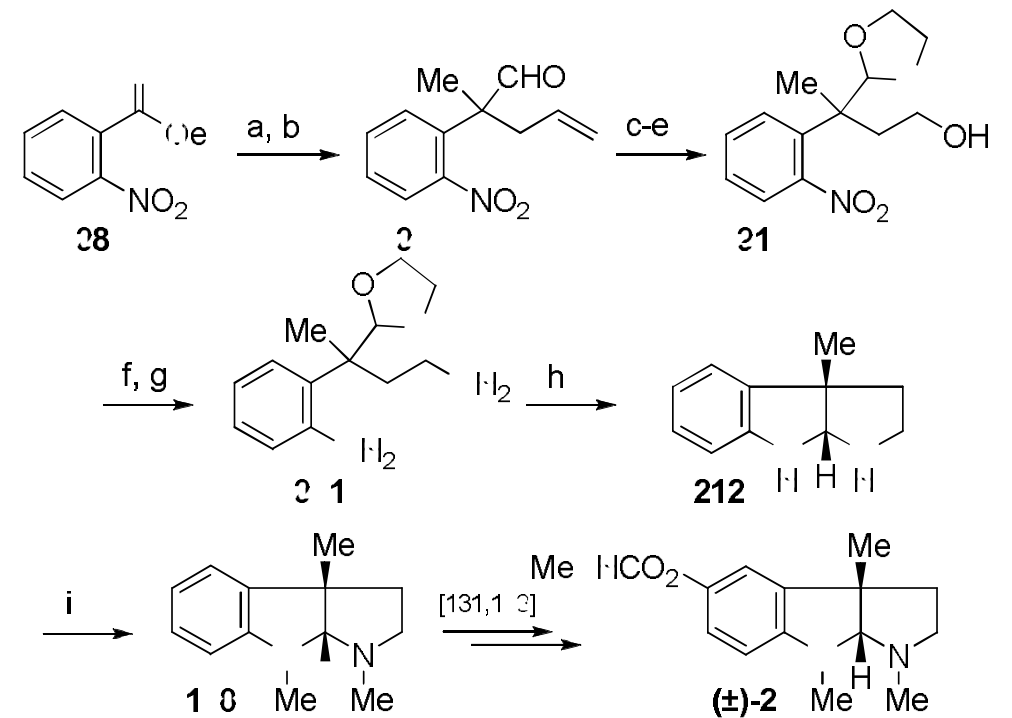

R egents: a. $\mathrm{CH}_{2}=\mathrm{CHCH}_{2} \mathrm{OCH}_{2} \mathrm{Ph}_{3} \mathrm{Cl}$, Nat-BuO, $\because \mathrm{F}, 0^{\circ} \mathrm{C}$; b. xylene, reflux, 5\% (2 steps); c. $p$ - :A, ethylene glycol, toluene, reflux; d. $\mathrm{O}_{3}, \mathrm{SMe}_{2}, \mathrm{CH}_{2} \mathrm{Cl}_{2}, 0^{\circ} \mathrm{C}, 8 \%$ (2 steps); e. $\mathrm{NaBH}_{4}$, aq.

'F, $92 \%$; f. DIAD, $\mathrm{Ph}_{3}$, phtha imide, $\mathrm{CH}_{3} \quad \mathrm{l} \cdot \mathrm{l}_{2}$, reflux, $68 \%$; g. NiRaney, $\mathrm{H}_{2}, \mathrm{MeOH}, 82 \%$; h. $p$ - $\quad \mathrm{A}$, aq. $\because \mathrm{F}$, reflux, $65 \%$;. aq. $\mathrm{HCHO}, 10 \% \mathrm{Pd}-\mathrm{C}, \mathrm{Et} \therefore \mathrm{C}, \mathrm{H}_{2}, \quad 0 \%$

Scheme 40 . Synthesis of $( \pm)$-physostigmine (2) by Kulkarni et al. ${ }^{[208]}$

\subsection{Aza-Pauson-Khand cyclocarbonylation (K, Figure 5)}

$( \pm)$-Physostigmine 2 has also been synthesized by subjecting an alkynecarbodiimide to an APKR with $\mathrm{Co}_{2}(\mathrm{CO})_{8}$ as catalyst (Scheme 41). ${ }^{[209,210]}$ Under $\mathrm{Co}_{2}(\mathrm{CO})_{8}$-catalyzed cyclocarbonylation conditions, the carbodiimide 213 was transformed into the pyrrolo[2,3-b]indol-2-one 214. One-pot reduction, hydroxymethylation, and $N$-methylation of 214 gave 215 as a single stereoisomer in good yield. Removal of the TMS and hydroxyl groups in $\mathbf{2 1 5}$, followed by reduction of the resulting lactam, gave $( \pm)$-esermethole 112 in high yields. 

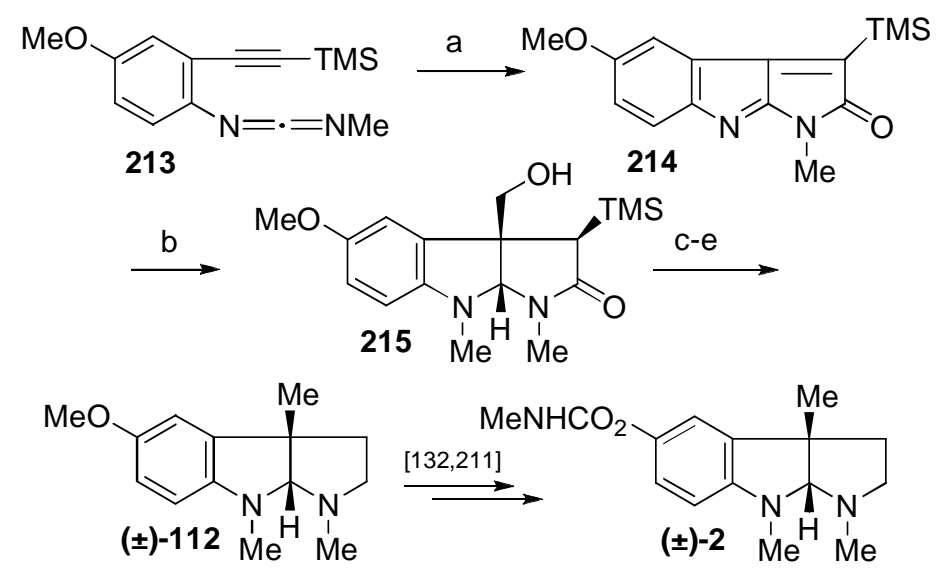

Reagents: a. $\mathrm{Co}_{2}(\mathrm{CO})_{8}, \mathrm{TMTU}$, benzene, $\mathrm{CO}(1 \mathrm{~atm}), 70 \stackrel{\circ}{\mathrm{C}} \mathrm{C}$, $55 \%$; b. $\mathrm{NaCNBH}_{3}$, aq. $\mathrm{HCHO}, \mathrm{AcOH}, \mathrm{MeCN}, 0 \stackrel{\circ}{\circ} \mathrm{C}, 79 \%$; c. TBAF, THF, reflux, $96 \%$; d. $\mathrm{I}_{2}, \mathrm{PPh}_{3}$, imidazole, $\mathrm{CHCl}_{3}$, reflux, $78 \%$; e. $\mathrm{LiAlH}_{4}$, THF, reflux, $83 \%$

Scheme 41. Formal synthesis of $( \pm)$-physostigmine (2) by aza-Pauson-Khand formation of $\mathrm{HPI}^{[210]}$

$( \pm)$-Flustramine B (4), ( \pm )-debromoflustramine B $(69), \quad( \pm)$-debromoflustramide $B, \quad( \pm)$ debromoflustramine $E,( \pm)$-flustramine $E$ and $( \pm)$-debromoflustramide $E$ were prepared ${ }^{[210]}$ from pyrrolo[2,3-b]indol-2-ones via APKR of alkynecarbodiimides.

\subsection{Synthesis of natural products containing a $N^{\text {ind }}-C^{3 a}$ bond}

Takayama et al. were the first to synthesize a natural product containing a $N^{\text {ind }}$ - $C^{3 a}$ bond characteristic of psychotrimine (49). ${ }^{[212]}$ In fact, the $N^{\text {ind }}-C^{3 a}$ bond was the first bond formed in their sequence (Scheme 42), via Strecker reaction of 2-bromobenzaldehyde and indoline to give 218. Introduction of a nitro-chain alpha to the cyano group of 218, and oxidation of the indoline, gave compound 219, containing all the atoms needed for elegant construction of 3a-indolyl-HPI 221. Reduction of the nitro group in $\mathbf{2 1 9}$ gave the primary amine, which spontaneously cyclized to amidine 220, whose pyrrolidine nitrogen was then Boc-protected. Finally, copper-mediated intramolecular amination afforded 221, which was then transformed into 222 via reduction of the Boc-protecting group to methyl, protection of $N^{8}$, regioselective iodination, and lastly, introduction of nitroethyl at position 3 of the indole. Finally, conversion of the nitro group in 222 into the NMe, followed by copper mediated intermolecular coupling of iodide 222 with tryptamine 223 and subsequent deprotection afforded 49. 

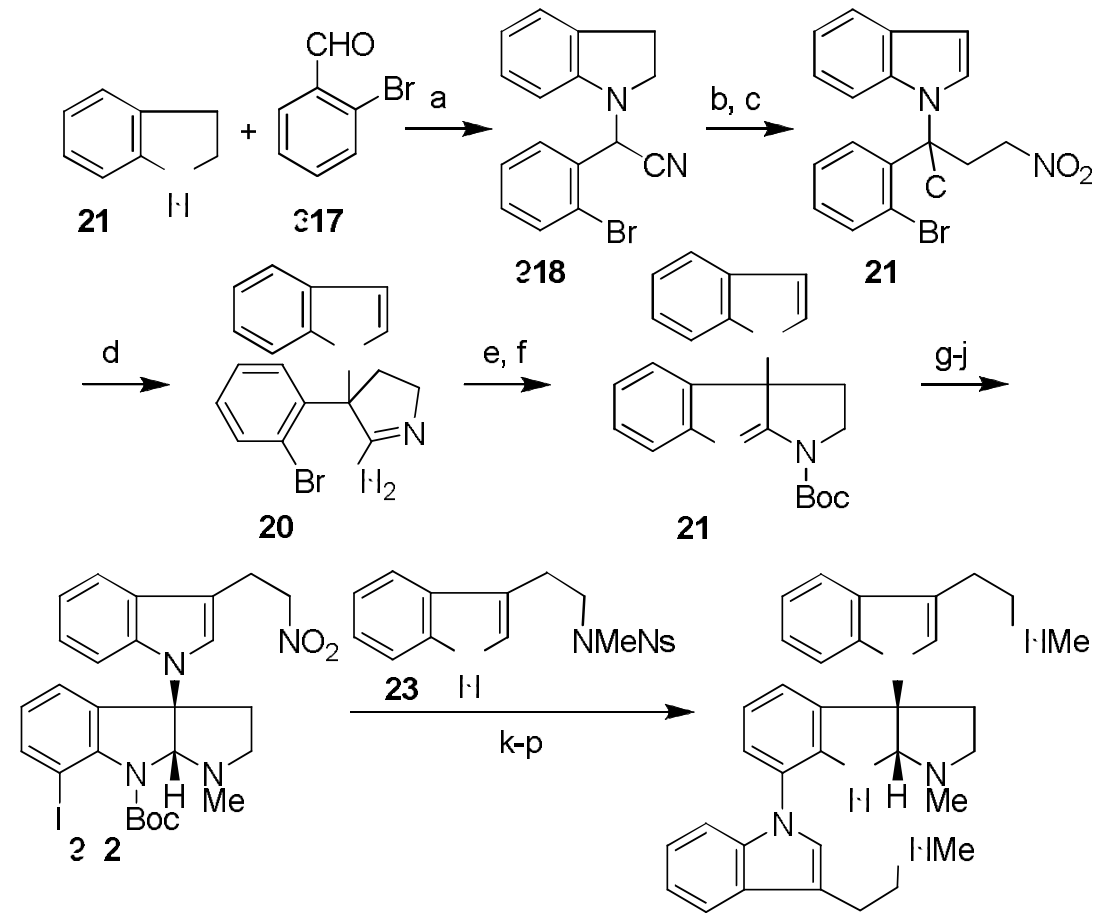

$( \pm)-4$

R egents: a. $\mathrm{KCN}$, aq $\mathrm{HCl}, \mathrm{MeCN}$, it, 92\%; b. I.IMDS, $\mathrm{CH}_{2}=\mathrm{C} \quad 1 \cdot 1 \mathrm{O}_{2}$, $\because F,-78^{\circ} \mathrm{C}$; C. DQ, 1,4 -di ::ane, $5^{\circ} \mathrm{C}, 0 \%$ (2 steps); d. Fe powder, aq $\mathrm{HCl}, \mathrm{EtOH}$, reflux; e. $\mathrm{Boc}_{2} \mathrm{O}, i-\mathrm{Pr}_{2} \mathrm{NEt}, \mathrm{MeCN}$, rt, $8 \%$ (2 steps); f. $\mathrm{Cul}, \mathrm{K}_{3} \mathrm{PO}_{4}$, DMSO, $0^{\circ} \mathrm{C}, 91 \%$; g. Red-Al, toluene, 0 to $0^{\circ} \mathrm{C}, 60 \%$; $\mathrm{h}$. I.IMDS, Boc $2 \mathrm{O}, \because \mathrm{F},-78$ to $0{ }^{\circ} \mathrm{C}$;. s-BuLi, TMEDA, I $, \because \mathrm{F},-78$ to 0 ${ }^{\circ} \mathrm{C}, 87 \%$ (2 steps); j. $\operatorname{InBr} 3, \mathrm{CH}_{2}=\mathrm{C} \quad 1 \cdot 1 \mathrm{O}_{2}, \mathrm{CH}_{2} \mathrm{Cl}_{2}$, rt, 86\%; k. Fe powder, $\mathrm{AcOH}, \mathrm{EtOH}$, di ::ane, reflux ; $\mathrm{NsCl}, \mathrm{Et}_{3} \mathrm{~N}_{2} \mathrm{CH}_{2} \mathrm{Cl}_{2}, \mathrm{rt}, 3 \%$ (2 steps); m. DBU, $\mathrm{Me}_{2} \mathrm{SO}_{4}, \mathrm{DMF}, 0^{\circ} \mathrm{C}, 94 \%$; n. TMSOTf, 2,6-lutidine, $\mathrm{CH}_{2} \mathrm{Cl}_{2}, 0$ ${ }^{\circ} \mathrm{C}$ to rt, $87 \%$; O. 23, Cul, $\mathrm{K}_{3} \mathrm{PO}_{4}, N, N^{\prime}$-dimethylethylenediamine, 1,4-

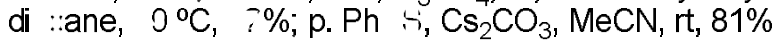

Scheme 42 . Synthesis of $( \pm)$-psychotrimine $(\mathbf{4 9})$ by Takayama et al. ${ }^{[212]}$

Rainier and Espejo described an alternate strategy to $N^{\text {ind }}-C^{3 a}$ bond formation: reaction of an $3 a-$ bromo-HPIC and an indole derivative. ${ }^{[213]}$ Compound 224 was subjected to base-catalyzed nucleophilic substitution with indole derivatives, yielding a mixture of diastereomers in which the endo product was predominant (Scheme 43).

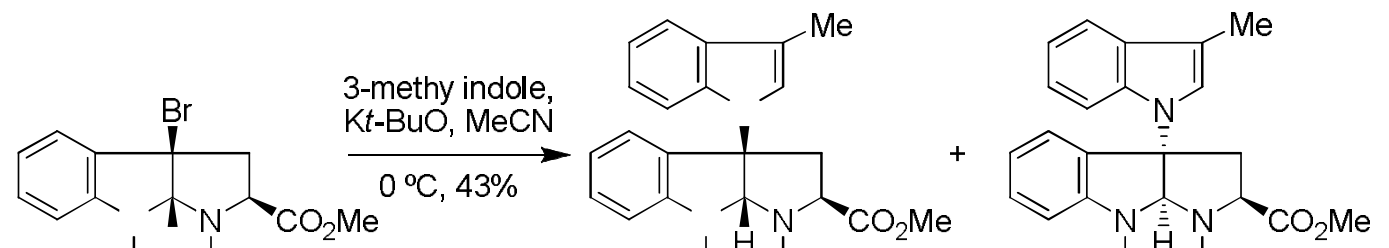

24 Boc Boc exo- 25 Boc Boc endo- 25 BoC Boc

Scheme 43. Synthesis of 3a-indolyl-HPIC by Rainier and Espejo ${ }^{[213]}$

Baran et al. prepared psychotrimine (49) via an elegant synthesis based on the simultaneous formation of the tricyclic system of HPI and the $N-C^{3 a}$ bond (Scheme 44). ${ }^{[214]}$ The starting material was bromotryptamine 226, which was reacted with NIS and 2-iodoaniline to form HPI derivative 
228. Chemoselective Larock annulation ${ }^{[215]}$ between 228 and an alkyne afforded 230. Transformation of $\mathbf{2 3 0}$ into ( \pm )-49 follows a similar procedure as that detailed in Scheme 42.

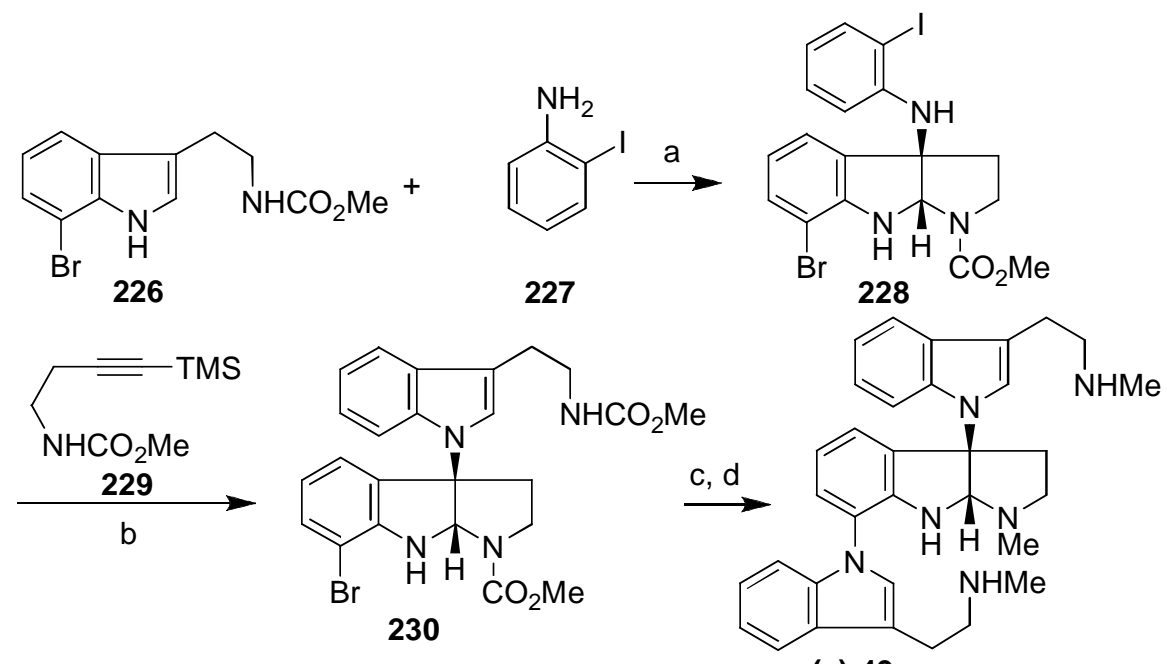

$( \pm)-49$

Reagents: a. NIS, $\mathrm{Et}_{3} \mathrm{~N}, \mathrm{MeCN},-45$ to $23 \stackrel{\circ}{\mathrm{C}}, 61-67 \%$; b. $\mathrm{Pd}(\mathrm{OAc})_{2}, \mathrm{Na}_{2} \mathrm{CO}_{3}, \mathrm{LiCl}$, DMF, $102 \stackrel{\circ}{\circ}$, 85\%; c. Cul, ( \pm )-trans- $N, N$ '-dimethyl-1,2-cyclohexanediamine, $\mathrm{K}_{2} \mathrm{CO}_{3}, N^{b}$-(methoxycarbonyl)tryptamine, 1,4-dioxane, $101 \stackrel{\circ}{\circ} \mathrm{C}, 89 \%$; d. Red-Al, toluene, $110 \stackrel{\circ}{\mathrm{C}}, 89 \%$

Scheme 44 . Synthesis of $( \pm)$-psychotrimine $(49)$ by Baran et al. ${ }^{[14]}$

Recently, Baran et al. employed a similar strategy to synthesize kapakahines B (235) and F (234) (Scheme 49). ${ }^{[216]}$ Reaction of the dipeptide 231 with o-iodoaniline and NIS under simultaneous cyclization-amination gave compound 232. Larock annulation of 232 with the tripeptide 236 gave 233. Interestingly, the HPIC-opening in this synthesis occurs after the Cbz elimination and the new double-ring closure, to give the $\alpha$-carboline condensed to an imidazolidinone unit characteristic of kapakahines. 


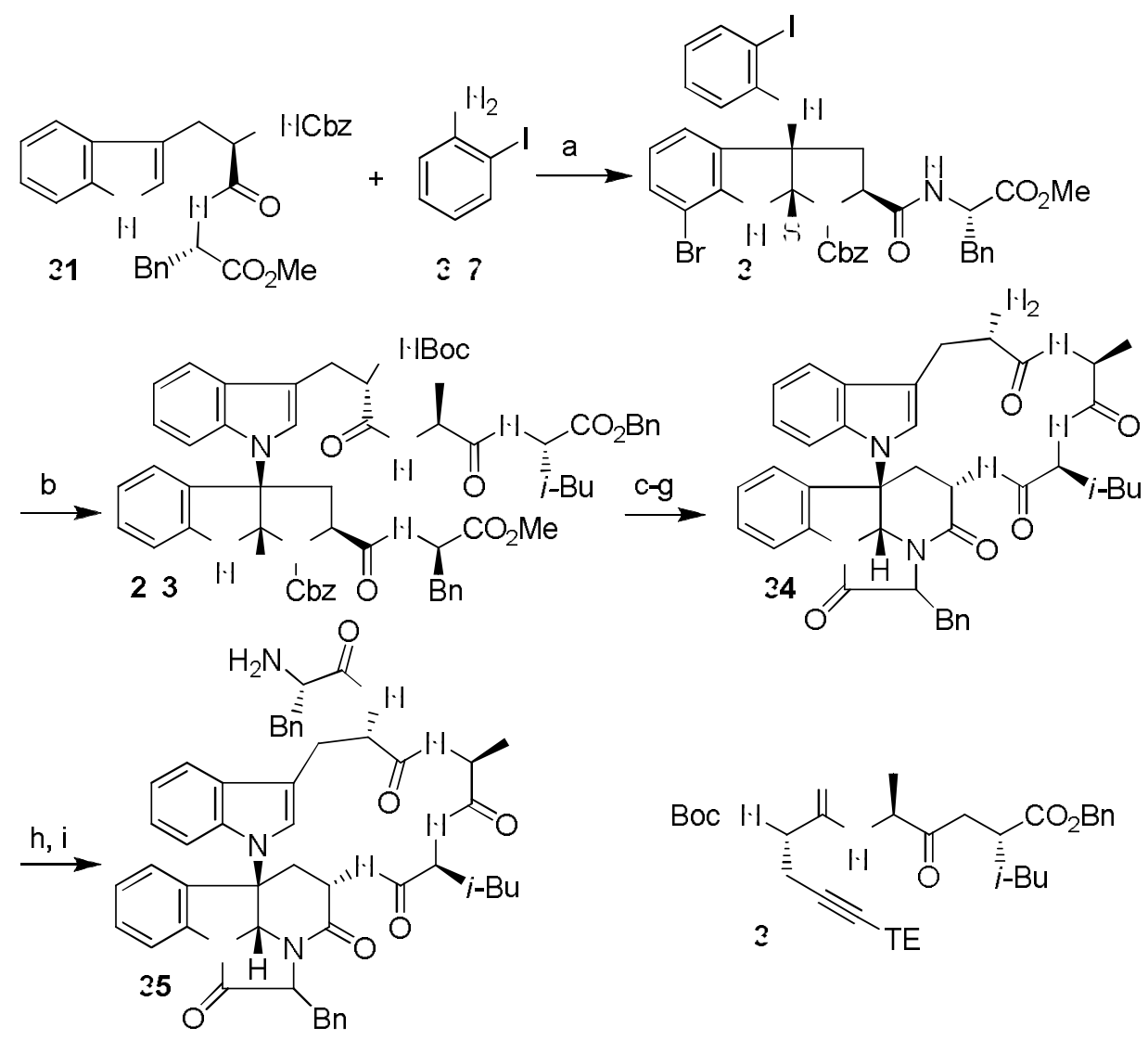

R egents: a. NIS, MeCN, -45 to $-3^{\circ} \mathrm{C}, 65 \%$; b. $\mathrm{Pd}(\mathrm{OAc})_{2}, \mathrm{NaOAc}, \mathrm{LiCl}, 36, \mathrm{DMF}$, $10^{\circ} \mathrm{C}, 49 \%$; c. $10 \% \mathrm{Pd} / \mathrm{C}, \mathrm{H}_{2}, \mathrm{MeOH}$; d. EDC, $\mathrm{HOAt}, \mathrm{CH}_{2} \mathrm{Cl}_{2}-\mathrm{DMF}(20: 1), \quad-\%(2$ steps); e. $\mathrm{LiOH}, \quad \because \mathrm{F} / \mathrm{H}_{2} \mathrm{O} / \mathrm{MeOH}$; f. $(\mathrm{COCl})_{2}, \mathrm{Et}_{3} \mathrm{~N}, \mathrm{CH}_{2} \mathrm{Cl}_{2} ; \mathrm{g}$. TFA/CH $\mathrm{CH}_{2}(1: 10)$, :\% (3 steps); h. Boc-Phe-OH, EDC, $\mathrm{HOBt}, \mathrm{Et}_{3} \mathrm{~N}, \mathrm{CH}_{2} \mathrm{Cl}_{2} ; \mathrm{TFA}^{2} \mathrm{CH}_{2} \mathrm{Cl}_{2}(1: 10), 81 \%$ (2 steps)

Scheme 45. Synthesis of kapakahines B (235) and F (234) by Baran et al. ${ }^{[16]}$

\section{Summary and Outlook}

Since the isolation of physostigmine in 1864, many natural products containing HPI and HPIC have been isolated, above all in the past few decades. Furthermore, a new characteristic trait has been reported in some recently isolated natural products: a bond between the $C^{3 a}$ of the HPI or HPIC and the $N^{\text {ind }}$ of a tryptamine or Trp. Some of these compounds are macrocyclic peptides, which contain both the HPIC and the Trp in the peptide chain.

This report has covered synthetic routes to natural products containing one or more HPI and/or HPIC units. The smallest and simplest of these compounds have been prepared via classical indole chemistry, whereas the larger, more complex structures have inspired new synthetic methodologies that exploit a full arsenal of transformations, including oxidative cyclization, $\mathrm{Pd}$ catalyzed reactions as Larock annulations, and enzyme-catalyzed reactions between others. Researchers will undoubtedly harness this new chemistry to further advance work on natural products containing HPIs and/or HPICs. 
Many of these natural products present a wide range of biological activities, encompassing acylCoA inhibitors, neuropeptide neurotransmitter antagonists, topoisomerase inhibitors, and antibiotics. Thus, it is easy to envisage that in a near future, some of these natural products or their analogs will enter into clinical trials, which will require the need of having bigger quantities. The synthetic routes described in this review should be the base for developing industrial strategies required for these natural products be considered as potential drugs.

The authors' laboratory is partially supported by PharmaMar (Madrid), CICYT (CTQ200603794/BQU), the Instituto de Salud Carlos III (CB06_01_0074), the Generalitat de Catalunya (2009SGR 1024), the Institute for Research in Biomedicine, and the Barcelona Science Park.

\section{Abbreviations}

$\begin{array}{ll}\text { Ac } & \text { acyl } \\ \text { AcOH } & \text { acetic acid } \\ \text { AIBN } & \text { azobisisobutyronitrile } \\ \text { Anth } & \text { 9-anthracenyl } \\ \text { APKR } & \text { aza-Pauson-Khand reaction } \\ \text { BINAP } & 2,2 \text {-bis(diphenylphosphino)-1,1'-binaphthyl } \\ \text { Bn } & \text { benzyl } \\ \text { Boc } & \text { tert-butoxycarbonyl } \\ \text { BOP } & \text { (benzotriazol-1-yloxy)tris(dimethylamino)phosphonium hexafluorophosphate } \\ \text { BTMAB } & \text { benzyltrimethylammonium tribromide } \\ \text { Cbz } & \text { benzyloxycarbonyl } \\ \text { mCPBA } & \text { m-chloroperbenzoic acid } \\ \text { dba } & \text { dibenzylideneacetone } \\ \text { DBU } & 1,8 \text {-diazabicyclo[5.4.0]undec-7-ene } \\ \text { DCC } & \text { dicyclohexylcarbodiimide } \\ \text { DDQ } & 2,3 \text {-dichloro-5,6-dicyanobenzoquinone } \\ \text { de } & \text { diastereomeric excess } \\ \text { DIAD } & \text { diisopropyl azodicarboxylate } \\ \text { DIEA } & N, N \text {-diisopropylethylamine } \\ \text { DKP } & \text { diketopiperazine } \\ \text { DMA } & N, N \text {-dimethylacetamide } \\ \text { DMAP } & \text { 4-dimethylaminopyridine } \\ \text { DMAPP } & \text { dimethyl allyl diphosphate } \\ \text { DMDO } & 2,2 \text {-dimethyldioxirane } \\ \text { DMF } & N, N \text {-dimethylformamide } \\ \text { DMP } & \text { Dess-Martin periodinane } \\ \text { DMPU } & 1,3 \text {-dimethyl-3,4,5,6-tetrahydro-2(1H)-pyrimidinone } \\ \text { DMSO } & \text { dimethyl sulfoxide } \\ \text { EDC } & 1 \text {-ethyl-3-(3-dimethylaminopropyl)carbodiimide } \\ \text { ee } & \text { enantiomeric excess } \\ \text { Fmoc } & 9 H \text {-fluoren-9-ylmethoxycarbonyl } \\ \text { HATU } & 2 \text {-(7-aza-1H-benzotriazole-1-yl)-1,1,3,3-tetramethyluronium hexafluorophosphate } \\ \text { HOAt } & 1 \text {-hydroxy-7-azabenzotriazole } \\ \text { HOBt } & \text { 1-hydroxybenzotriazole } \\ & \end{array}$




$\begin{array}{ll}\text { HPI } & \text { hexahydropyrrolo[2,3-b]indole } \\ \text { HPIC } & \text { hexahydropyrrolo[2,3-b]indole-2-carboxylate or -carboxamide } \\ \text { KHMDS } & \text { potassium bis(trimethylsilyl)amide } \\ \text { LDA } & \text { lithium diisopropylamide } \\ \text { LHMDS } & \text { lithium hexamethyldisilazide } \\ \text { MOM } & \text { methoxymethyl } \\ \text { MTAD } & N \text {-methyl-1,3,4-triazoline-2,5-dione } \\ \text { NBS } & N \text {-bromosuccinimide } \\ \text { NCS } & \text {-chlorosuccinimide } \\ \text { NHMDS } & \text { sodium bis(trimethylsilyl)amide } \\ \text { NIS } & \text { N-iodosuccinimide } \\ \text { NMO } & N \text {-methylmorpholine- } N \text {-oxide } \\ \text { Ns } & \text { 4-nitrobenzenesulfonyl (nosyl) } \\ \text { ONB } & o \text {-nitrobenzyl } \\ \text { PCC } & \text { pyridinium chlorochromate } \\ \text { PMP } & 1,2,2,6,6 \text {-pentamethylpiperidine } \\ \text { PPTS } & \text { pyridinium } p \text {-toluenesulfonate } \\ \text { Pyr } & \text { pyridine } \\ \text { N-PSP } & N \text {-(phenylseleno)phthalimide } \\ \text { Red-Al } & \text { sodium bis(2-methoxyethoxy)aluminum hydride } \\ \text { TASF } & \text { tris(dimethylamino)sulfonium difluorotrimethylsilicate } \\ \text { TBAB } & \text { tetrabutylammonium bromide } \\ \text { TBAF } & \text { tetra- } n \text {-butylammonium fluoride } \\ \text { TBAHS } & \text { tetrabutylammonium hydrogen sulfate } \\ \text { TBS } & \text { tert-butyldimethylsilyl } \\ \text { TBSCl } & \text { tert-butyldimethylsilyl chloride } \\ \text { TIPS } & \text { triisopropylsilyl } \\ \text { Tf } & \text { triflate } \\ \text { TFA } & \text { trifluoroacetic acid } \\ \text { TFAA } & \text { trifluoroacetic anhydride } \\ \text { THF } & \text { tetrahydrofuran } \\ \text { Teoc } & 2 \text {-trimethylsilylethoxycarbonyl } \\ \text { TMEDA } & \text { tetramethylethylenediamine } \\ \text { TMS } & \text { trimethylsilyl } \\ \text { TMSCN } & \text { trimethylsilyl cyanide } \\ \text { TMSCl } & \text { trimethylsilyl chloride } \\ \text { TMSI } & \text { trimethylsilyliodide } \\ \text { TMSOTf } & \text { trimethylsilyl trifluoromethanesulfonate } \\ \text { TMTU } & \text { tetramethylthiourea } \\ \text { Tr } & \text { triphenylmethyl (trityl) } \\ \text { Ts } & p \text {-toluenesulfonyl (tosyl) } \\ \text { p-TSA } & p \text {-toluenesulfonic acid } \\ & \end{array}$

\section{References}

[1] B. Tashkhodzhaev, K. Samikov, M.R. Yagudaev, T.P. Antsupova, R. Shakirov, S.Y. Yunusov, Khimiya Prirodnykh Soedinenii 1985, 5, 687-691.

[2] K. Samikov, R. Shakirov, T.P. Antsupova, S.Y. Yunusov, Khimiya Prirodnykh Soedinenii 1986, 3, 383.

[3] B. Witkop, Heterocycles 1998, 49, 9-27.

[4] J.S. Carlé, C. Christophersen, J. Am. Chem. Soc. 1979, 101, 4012-4013.

[5] J.S. Carlé, C. Christophersen, J. Org. Chem. 1980, 45, 1586-1589.

[6] J.S. Carlé, C. Christophersen, J. Org. Chem. 1981, 46, 3440-3443.

[7] M.V. Laycock, J.L.C. Wright, J.A. Findlay, A.D. Patil, Can. J. Chem. 1986, 64, 1312-1316.

[8] P.B. Holst, U. Anthoni, C. Christophersen, P.H. Nielsen, J. Nat. Prod. 1994, 57, 997-1000.

[9] S.J. Rochfort, S. Moore, C. Craft, N.H. Martin, R.M. Van Wagoner, J.L.C. Wright, J. Nat. Prod. 2009, 72, $1773-1781$.

[10] P. Wulff, J.S. Carlé, C. Christophersen, Comp. Biochem. Physiol. B: Biochem. Mol. Biol. 1982, 71, 523-524. 
P. Keil, E.G. Nielsen, U. Anthoni, C. Christophersen, Acta Chem. Scand. 1986, 40B, 555-558.

[12] J.L.C. Wright, J. Nat. Prod. 1984, 47, 893-895.

[13] L. Peters, G.M. Konig, H. Terlau, A.D. Wright, J. Nat. Prod. 2002, 65, 1633-1637. The correct relative configuration of the stereocenter $3 a$ is $S$ and nor $R$, as it is indicated in the compound name.

[14] Y.-H. Wang, C.-L. Long, F.-M. Yang, X. Wang, Q.-Y. Sun, H.-S. Wang, Y.-N. Shi, G.-H. Tang, J. Nat. Prod. 2009, 72, 11511154.

[15] T.F. Spande, M.W. Edwards, L.K. Pannell, J.W. Daly, V. Erspamer, P. Melchiorri, J. Org. Chem. 1988, 53, $1222-1226$.

[16] H. Hayashi, K. Takiuchi, S. Murao, M. Arai, Agric. Biol. Chem. 1989, 53, 461-469.

[17] H. Hayashi, T. Fujiwara, S. Murao, M. Arai, Agric. Biol. Chem. 1991, 55, 3143-3145.

[18] H. Hayashi, Y. Asabu, S. Murao, M. Arai, Biosci., Biotechnol., Biochem. 1995, 59, $246-250$.

[19] H. Hayashi, A. Sakaguchi, Biosci., Biotechnol., Biochem. 1998, 62, 804-806.

[20] H. Hayashi, K. Furutsuka, Y. Shiono, J. Nat. Prod. 1999, 62, 315-317.

[21] Y. Shiono, K. Akiyama, H. Hayashi, Biosci., Biotechnol., Biochem. 1999, 63, 1910-1920.

[22] Y. Shiono, K. Akiyama, H. Hayashi, Biosci., Biotechnol., Biochem. 2000, 64, 103-110.

[23] C. Takahashi, A. Numata, Y. Ito, E. Matsumura, H. Araki, H. Iwaki, K. Kushida, J. Chem. Soc., Perkin Trans. 1 1994, 18591864.

[24] J.-Y. Dong, H.-P. He, Y.-M. Shen, K.-Q. Zhang, J. Nat. Prod. 2005, 68, 1510-1513.

[25] Y. Usami, J. Yamaguchi, A. Numata, Heterocycles 2004, 63, 1123-1129.

[26] G. Carr, W. Tay, H. Bottriell, S.K. Andersen, A.G. Mauk, R.J. Andersen, Org. Lett. 2009, 11, $2996-2999$.

[27] M. Varoglu, T.H. Corbett, F.A. Valeriote, P. Crews, J. Org. Chem. 1997, 62, 7078-7079.

[28] R. Raju, A.M. Piggott, M. Conte, W.G.L. Aalbersberg, K. Feussner, R.J. Capon, Org. Lett. 2009, $11,3862-3865$.

[29] M. Kusano, G. Sotoma, H. Koshino, J. Uzawa, M. Chijimatsu, S. Fujioka, T. Kawano, Y. Kimura, J. Chem. Soc., Perkin Trans. 1 1998, 2823-2826.

[30] Y. Kimura, A. Sawada, M. Kuramata, M. Kusano, S. Fujioka, T. Kawano, A. Shimada, J. Nat. Prod. 2005, 68, $237-239$.

[31] L. Du, X. Yang, T. Zhu, F. Wang, X. Xiao, H. Park, Q. Gu, Chem. Pharm. Bull. 2009, 57, $873-876$.

[32] J.E. Hochlowski, M.M. Mullally, S.G. Spanton, D.N. Whitttern, P. Hill, J.B. McAlpine, J. Antibiot. 1993, 46, $380-386$.

[33] S. Ohmomo, T. Sato, T. Utagawa, M. Abe, Agric. Biol. Chem. 1975, 39, 1333-1334.

[34] S. Ohmomo, T. Utagawa, M. Abe, Agric. Biol. Chem. 1977, 41, 2097-2098.

[35] S. Ohmomo, K. Oguma, T. Ohashi, M. Abe, Agric. Biol. Chem. 1978, 12, 2387-2389.

[36] L. Du, D. Li, T. Zhu, S. Cai, F. Wang, X. Xiao, Q. Gu, Tetrahedron 2009, 65, 1033-1039.

[37] Y. Kimura, T. Hamasaki, H. Nakajima, A. Isogai, Tetrahedron Lett. 1982, 23, 225-228.

[38] A.J. Birch, J.J. Wright, J. Chem. Soc. D, Chem. Commun. 1969, 12, 644-645.

[39] R.L.M. Synge, E.P. White, N. Zeal. J. Agric. Res. 1960, 3, 907-921.

[40] J. Fridrichsons, A.McL. Mathieson, Tetrahedron Lett. 1962, 3, 1265-1268.

[41] J.W. Ronaldson, A. Taylor, E.P. White, R.J. Abraham, J. Chem. Soc. 1963, 3172-3180.

[42] R. Hodges, J.S. Shannon, Aust. J. Chem. 1966, 19, 1059-1066.

[43] H. Kato, T. Yoshida, T. Tokue, Y. Nojiri, H. Hirota, T. Ohta, R.M. Williams, S. Tsukamoto, Angew. Chem. Int. Ed. 2007, 46, 2254-2256.

[44] S. Takase, M. Iwami, T. Ando, M. Okamoto, K. Yoshida, H. Horiai, M. Kohsaka, H. Aoki, H. Imanaka, J. Antibiot. 1984, 37, 1320-1323.

[45] S. Takase, Y. Kawai, I. Uchida, H. Tanaka, H. Aoki, Tetrahedron 1985, 41, 3037-3048.

[46] C. Shinohara, K. Hasumi, Y. Takei, A. Endo, J. Antibiot. 1994, 47, 163-167.

[47] B. Nuber, F. Hansske, C. Shinohara, S. Miura, K. Hasumi, A. Endo, J. Antibiot. 1994, 47, $168-172$.

[48] H.F. Hodson, B. Robinson, G.F. Smith, Proc. Chem. Soc. 1961, 465-466.

[49] T. Tokuyama, J.W. Daly, Tetrahedron 1983, 39, 41-47.

[50] V. Jannic, F. Gueritte, O. Laprevote, L. Serani, M.-T. Martin, T. Sévenet, P. Potier, J. Nat. Prod. 1999, 62, 838-843.

[51] H. Takayama, Y. Matsuda, K. Masubuchi, A. Ishida, M. Kitajima, N. Aimi, Tetrahedron 2004, 60, 893-900.

[52] L. Verotta, T. Pilati, M. Tato, E. Elisabetsky, T.A. Amador, D.S. Nunes, J. Nat. Prod. 1998, 61, $392-396$.

[53] Y. Adjibade, B. Weniger, J.C. Quirion, B. Kuballa, P. Cabalion, R. Anton, Phytochemistry 1992, 31, 317-319.

[54] J.-W. Zhang, J.-M. Gao, T. Xu, X.-C. Zhang, Y.-T. Ma, S. Jarussophon, Y. Konishi, Chem. Biodiversity 2009, 6, 838-845.

[55] K. Eiter, O. Svierak, Monatsh. Chem. 1951, 82, 186-188.

[56] K. Eiter, O. Svierak, Monatsh. Chem. 1952, 83, 1453-1476.

[57] M. Movassaghi, M.A. Schmidt, Angew. Chem. Int. Ed. 2007, 46, 3725-3728.

[58] F. Guéritte-Voegelein, T. Sévenet, J. Pusset, M.-T. Adeline, B. Gillet, J.-C. Beloeil, D. Guénard, P. Potier, R. Rasolonjanahary, C. Kordon, J. Nat. Prod. 1992, 55, 923-930.

[59] R.K. Duke, R.D. Allan, G.A.R. Johnston, K.N. Mewett, A.D. Mitrovic, C.C. Duke, T.W. Hambley, J. Nat. Prod. 1995, 58, 12001208.

[60] E.F.L.J. Anet, G.K. Hughes, E. Ritchie, Aust. J. Chem. 1961, 14, 173-174.

[61] F. Libot, C. Miet, N. Kunesch, J.E. Poisson, J. Pusset, T. Sévenet, J. Nat. Prod. 1987, 50, 468-473.

[62] H. Takayama, I. Mori, M. Kitajima, N. Aimi, N.H. Lajis, Org. Lett. 2004, 6, 2945-2948.

[63] K.P. Parry, G.F. Smith, J. Chem. Soc., Perkin Trans. 11978, 1671-1682.

[64] C.J. Barrow, P. Cai, J.K. Snyder, D.M. Sedlock, H.H. Sun, R. Cooper, J. Org. Chem. 1993, 58, 6016-6021.

[65] D.M. Sedlock, C.J. Barrow, J.E. Brownell, A. Hong, A.M. Gillum, D.R. Houck, J. Antibiot. 1994, 47, $391-398$.

[66] J.J. Oleynek, D.M. Sedlock, C.J. Barrow, K.C. Appell, F. Casiano, D. Haycock, S.J. Ward, P. Kaplita, A.M. Gillum, J. Antibiot. 1994, 47, 399-410.

[67] J.P. Springer, G. Buchi, B. Kobbe, A.L. Demain, J. Clardy, Tetrahedron Lett. 1977, 18, $2403-2406$.

[68] S.P.B. Ovenden, G. Sberna, R.M. Tait, H.G. Wildman, R. Patel, B. Li, K. Steffy, N. Nguyen, B.M. Meurer-Grimes, J. Nat. Prod. 2004, 67, 2093-2095.

[69] D. Hauser, H.P. Weber, H.P. Sigg, Helv. Chim. Acta 1970, 53, 1061-1073.

[70] K. Katagiri, K. Sato, S. Hayakawa, T. Matsushima, H. Minato, J. Antibiot. 1970, 23, 420-422.

[71] H. Minato, M. Matsumoto, T. Katayama, J. Chem. Soc. D, Chem. Commun. 1971, 44-45.

[72] H. Minato, M. Matsumoto, T. Katayama, J. Chem. Soc., Perkin Trans. 1 1973, 1819-1825.

[73] B.W. Son, P.R. Jensen, C.A. Kauffman, W. Fenical, Nat. Prod. Lett. 1999, 13, 213 - 222.

[74] A.D. Argoudelis, F. Reusser, J. Antibiot. 1971, 24, 383-389.

[75] A.D. Argoudelis, J. Antibiot. 1972, 25, 171-178.

[76] A.D. Argoudelis, S.A. Mizsak, J. Antibiot. 1977, 30, 468-473. 
[77] M. Yanagihara, N. Sasaki-Takahashi, T. Sugahara, S. Yamamoto, M. Shinomi, I. Yamashita, M. Hayashida, B. Yamanoha, A. Numata, T. Yamori, T. Andoh, Cancer Sci. 2005, 96, 816-824.

[78] S.A. Waksman, E. Bugie, J. Bacteriol. 1944, 48, 527-530.

[79] W.B. Geiger, J.E. Conn, S.A. Waksman, J. Bacteriol. 1944, 48, 531-536.

[80] W.B. Geiger, Arch. Biochem. 1949, 21, 125-131.

[81] S. Safe, A. Taylor, J. Chem. Soc., Perkin Trans. 11972, 472-479.

[82] A.G. McInnes, A. Taylor, J.A. Walter, J. Am. Chem. Soc. 1976, 98, 6741-6741.

[83] T. Kikuchi, S. Kadota, K. Nakamura, A. Nishi, T. Taga, T. Kaji, K. Osaki, K. Tubaki, Chem. Pharm. Bull. 1982, 30, 3846-3848.

[84] G.-Y. Li, B.-G. Li, T. Yang, J.-F. Yan, G.-Y. Liu, G.-L. Zhang, J. Nat. Prod. 2006, 69, 1374-1376.

[85] B.K.S. Yeung, Y. Nakao, R.B. Kinnel, J.R. Carney, W.Y. Yoshida, P.J. Scheuer, M. Kelly-Borges, J. Org. Chem. 1996, 61, 71687173.

[86] E. Büchel, U. Martini, A. Mayer, H. Anke, O. Sterner, Tetrahedron 1998, 54, 5345-5352.

[87] J.C. Liermann, T. Opatz, H. Kolshorn, L. Antelo, C. Hof, H. Anke, Eur. J. Org. Chem. 2009, 1256-1262.

[88] G.R. Pettit, R. Tan, D.L. Herald, R.L. Cerny, M.D. Williams, J. Org. Chem. 1994, 59, $1593-1595$.

[89] J.E. Leet, D.R. Schroeder, B.S. Krishnan, J.A. Matson, J. Antibiot. 1990, 43, 961-966.

[90] J.E. Leet, D.R. Schroeder, J. Golik, J.A. Matson, T.W. Doyle, K.S. Lam, S.E. Hill, M.S. Lee, J.L. Whitney, B.S. Krishnan, J. Antibiot. 1996, 49, 299-311.

[91] T.M. Kamenecka, S.J. Danishefsky, Angew. Chem. Int. Ed. 1998, 37, 2993-2995.

[92] T.M. Kamenecka, S.J. Danishefsky, Angew. Chem. Int. Ed. 1998, 37, 2995-2998.

[93] K. Umezawa, Y. Ikeda, Y. Uchihata, H. Naganawa, S. Kondo, J. Org. Chem. 2000, 65, 459-463.

[94] Z. Guo, L. Shen, Z. Ji, J. Zhang, L. Huang, W. Wu, J. Antibiot. 2009, 62, 201-205.

[95] A. Broberg, A. Menkis, R. Vasiliauskas, J. Nat. Prod. 2006, 69, 97-102.

[96] A. Pohanka, A. Menkis, J. Levenfors, A. Broberg, J. Nat. Prod. 2006, 69, 1776-1781.

[97] M.A. Schmidt, M. Movassaghi, Synlett 2008, 313-324.

[98] A. Steven, L.E. Overman, Angew. Chem. Int. Ed. 2007, 46, 5488-5508.

[99] D. Crich, A. Banerjee, Acc. Chem. Res. 2007, 40, 151-161.

[100] S. Takano, K. Ogasawara, in The Alkaloids: Chemistry and Pharmacology, Vol. Volume 36 (Ed.: B. Arnold), Academic Press, New York, 1989, pp. 225-251.

[101] J. Sapi, G. Massiot, in The Alkaloids: Chemistry and Pharmacology, Vol. Volume 47 (Ed.: A.C. Geoffrey), Academic Press, New York, 1995, pp. 173-226.

[102] A. Brossi, X.F. Pei, N.H. Greig, Aust. J. Chem. 1996, 49, 171-181.

[103] G.A. Cordell, J.E. Saxton, in The Alkaloids: Chemistry and Physiology, Vol. Volume 20 (Eds.: R.H.F. Manske, R.G.A. Rodrigo), Academic Press, New York, 1981, pp. 10-25.

[104] J.W. Daly, H.M. Garraffo, T.F. Spande, in The Alkaloids: Chemistry and Pharmacology, Vol. Volume 43 (Ed.: A.C. Geoffrey), Academic Press, New York, 1993, pp. 257-261.

[105] J.T. Wróbel, in The Alkaloids: Chemistry and Pharmacology, Vol. Volume 26 (Ed.: B. Arnold), Academic Press, New York, 1985, pp. 70-81.

[106] T. Hino, M. Nakagawa, in The Alkaloids: Chemistry and Pharmacology, Vol. Volume 34 (Ed.: B. Arnold), Academic Press, New York, 1988, pp. 1-75.

[107] U. Anthoni, C. Christophersen, P.H. Nielsen, in Alkaloids: Chemical and Biological Perspectives, Vol. Volume 13 (Ed.: S.W. Pelletier), Pergamon, 1999, pp. 163-236.

[108] M. Taniguchi, T. Hino, Tetrahedron 1981, 37, 1487-1494.

[109] U. Anthoni, C. Christophersen, P.H. Nielsen, E.J. Pedersen, Acta Chem. Scand. 1994, 48, 91-93.

[110] U. Anthoni, C. Christophersen, P.H. Nielsen, E.J. Pedersen, Acta Chem. Scand. 1997, 51, 407-410.

[111] U. Anthoni, C. Christophersen, A. Obel, P.H. Nielsen, Acta Chem. Scand. 1994, 48, 334-339.

[112] M. Bruncko, D. Crich, R. Samy, J. Org. Chem. 1994, 59, 5543-5549.

[113] D.H.R. Barton, D. Crich, W.B. Motherwell, Tetrahedron 1985, 41, 3901-3924.

[114] M. Ohno, T.F. Spande, B. Witkop, J. Am. Chem. Soc. 1968, 90, 6521-6522.

[115] M. Ohno, T. Spande, B. Witkop, J. Am. Chem. Soc. 1970, 92, 343-348.

[116] A.S. Cardoso, N. Srinivasan, A.M. Lobo, S. Prabhakar, Tetrahedron Lett. 2001, 42, 6663-6666.

[117] A.S.P. Cardoso, M.M.B. Marques, N. Srinivasan, S. Prabhakar, A.M. Lobo, Tetrahedron 2007, 63, 10211-10225

[118] D.H.R. Barton, M. Samadi, Tetrahedron 1992, 48, 7083-7090.

[119] T.M. Kamenecka, S.J. Danishefsky, Chem. Eur. J. 2001, 7, 41-63.

[120] J. Kim, J.A. Ashenhurst, M. Movassaghi, Science 2009, 324, 238-241.

[121] C.S. López, C. Pérez-Balado, P. Rodríguez-Grana, Á.R. de Lera, Org. Lett. 2008, 10, 77-80.

[122] M. Nakagawa, T. Kaneko, H. Yamaguchi, T. Kawashima, T. Hino, Tetrahedron 1974, 30, $2591-2600$.

[123] A. Sakai, H. Tani, T. Aoyama, T. Shioiri, Synlett 1998, 257-258.

[124] P.S. Baran, C.A. Guerrero, E.J. Corey, J. Am. Chem. Soc. 2003, 125, 5628-5629.

[125] K.M. Depew, S.P. Marsden, D. Zatorska, A. Zatorski, W.G. Bornmann, S.J. Danishefsky, J. Am. Chem. Soc. 1999, 121, 1195311963.

[126] W.-C. Chen, M.M. Joullié, Tetrahedron Lett. 1998, 39, 8401-8404.

[127] B.M. Schiavi, D.J. Richard, M.M. Joullié, J. Org. Chem. 2002, 67, 620-624.

[128] S.V. Ley, E. Cleator, P.R. Hewitt, Org. Biomol. Chem. 2003, 1, 3492-3494.

[129] P.R. Hewitt, E. Cleator, S.V. Ley, Org. Biomol. Chem. 2004, 2, 2415-2417.

[130] M. Nakagawa, M. Kawahara, Org. Lett. 2000, 2, 953-955.

[131] M. Node, A. Itoh, Y. Masaki, K. Fuji, Heterocycles 1991, 32, 1705-1707.

[132] S. Takano, E. Goto, M. Hirama, K. Ogasawara, Chem. Pharm. Bull. 1982, 30, 2641-2643.

[133] P. Muthusubramanian, J.S. Carlé, C. Christophersen, Acta Chem. Scand. 1983, 37b, 803-807.

[134] J. Jensen, U. Anthoni, C. Christophersen, P.H. Nielsen, Acta Chem. Scand. 1995, 49, 68-71.

[135] M. Kawahara, A. Nishida, M. Nakagawa, Org. Lett. 2000, 2, 675-678.

[136] G.H. Tan, X. Zhu, A. Ganesan, Org. Lett. 2003, 5, 1801-1803.

[137] J.F. Austin, S.-G. Kim, C.J. Sinz, W.-J. Xiao, D.W.C. MacMillan, Proc. Natl. Acad. Sci. U. S. A. $2004,101,5482-5487$.

[138] M.O. Mitchell, P. Dorroh, Tetrahedron Lett. 1991, 32, 7641-7642.

[139] N. Shangguan, W.J. Hehre, W.S. Ohlinger, M.P. Beavers, M.M. Joullié, J. Am. Chem. Soc. 2008, $130,6281-6287$.

[140] N. Shangguan, M.M. Joullié, Tetrahedron Lett. 2009, 50, 6755-6757.

[141] B. He, H. Song, Y. Du, Y. Qin, J. Org. Chem. 2009, 74, 298-304. 
[142] W.-B. Yin, J. Cheng, S.-M. Li, Org. Biomol. Chem. 2009, 7, 2202-2207.

[143] M.S. Morales-Ríos, O.R. Suárez-Castillo, P. Joseph-Nathan, J. Org. Chem. 1999, 64, 1086-1087.

[144] M.S. Morales-Ríos, O.R. Suárez-Castillo, J.J. Trujillo-Serrato, P. Joseph-Nathan, J. Org. Chem. 2001, 66, 1186-1192.

[145] M.S. Morales-Ríos, O.R. Suárez-Castillo, P. Joseph-Nathan, Tetrahedron 2002, 58, 1479-1484.

[146] P.L. Julian, J. Pikl, J. Am. Chem. Soc. 1935, 57, 563-566.

[147] P.L. Julian, J. Pikl, D. Boggess, J. Am. Chem. Soc. 1934, 56, 1797-1801.

[148] P.L. Julian, J. Pikl, J. Am. Chem. Soc. 1935, 57, 539-544.

[149] M. Polonovski, C. Nitzberg, Bull. Soc. Chim. Fr. 1916, 19, 27-37.

[150] P.L. Julian, J. Pikl, J. Am. Chem. Soc. 1935, 57, 755-757.

[151] B. Schönenberger, A. Brossi, Helv. Chim. Acta 1986, 69, 1486-1497.

[152] Q.-S. Yu, A. Brossi, Heterocycles 1988, 27, 1709-1712.

[153] S. Horne, N. Taylor, S. Collins, R. Rodrigo, J. Chem. Soc., Perkin Trans. 11991, 3047-3051.

[154] P.A. Grieco, W.A. Carroll, Tetrahedron Lett. 1992, 33, 4401-4404

[155] M.S. Morales-Ríos, M.A. Bucio, C. García-Martínez, P. Joseph-Nathan, Tetrahedron Lett. 1994, 35, 6087-6088.

[156] M.S. Morales-Ríos, M.A. Bucio, P. Joseph-Nathan, Tetrahedron Lett. 1994, 35, 881-882.

[157] H. Ishibashi, T. Kobayashi, N. Machida, O. Tamura, Tetrahedron 2000, 56, 1469-1473.

[158] M.S. Morales-Ríos, N.F. Santos-Sánchez, P. Joseph-Nathan, J. Nat. Prod. 2002, 65, 136-141.

[159] M.S. Morales-Ríos, N.F. Santos-Sánchez, Y. Mora-Pérez, P. Joseph-Nathan, Heterocycles 2004, 63, 1131-1142.

[160] K. Asakawa, N. Noguchi, M. Nakada, Heterocycles 2008, 76, 183-190.

[161] M. Node, X.-J. Hao, K. Fuji, Chem. Lett. 1991, 20, 57-60.

[162] Q.-S. Yu, B.-Y. Lu, Heterocycles 1994, 39, 519-525.

[163] M. Pallavicini, E. Valoti, L. Villa, P. Lianza, Tetrahedron: Asymmetry 1994, 5, 111-116.

[164] A. Pinto, Y. Jia, L. Neuville, J. Zhu, Chem. Eur. J. 2007, 13, 961-967.

[165] Q.-S. Yu, W.-M. Luo, Y.-Q. Li, Heterocycles 1993, 36, 1279-1285.

[166] X.-F. Pei, N.H. Greig, J.L. Flippen-Anderson, S. Bi, A. Brossi, Helv. Chim. Acta 1994, 77, 1412-1422.

[167] X.-F. Pei, Q.-S. Yu, B.-Y. Lu, N.H. Greig, A. Brossi, Heterocycles 1996, 42, 229-236.

[168] T. Bui, S. Syed, C.F. Barbas III, J. Am. Chem. Soc. 2009, 131, 8758-8759.

[169] T.B.K. Lee, G.S.K. Wong, J. Org. Chem. 1991, 56, 872-875.

[170] M. Pallavicini, E. Valoti, L. Villa, I. Resta, Tetrahedron: Asymmetry 1994, 5, 363-370.

[171] X.-F. Pei, N.H. Greig, A. Brossi, Heterocycles 1998, 49, 437-444.

[172] Q.-S. Yu, N.H. Greig, H.W. Holloway, A. Brossi, J. Med. Chem. 1998, 41, 2371-2379.

[173] Q.-S. Yu, N.H. Greig, H.W. Holloway, A. Brossi, Heterocycles 1999, 50, 95-102.

[174] Q.-S. Yu, H.W. Holloway, T. Utsuki, A. Brossi, N.H. Greig, J. Med. Chem. 1999, 42, 1855-1861.

[175] X. Zhu, N.H. Greig, H.W. Holloway, N.F. Whittaker, A. Brossi, Q.-S. Yu, Tetrahedron Lett. 2000, 41, 4861-4864.

[176] Q.-S. Yu, X.-F. Pei, H.W. Holloway, N.H. Greig, A. Brossi, J. Med. Chem. 1997, 40, 2895-2901.

[177] W.Y. Sun, Y. Sun, Y.C. Tang, J.Q. Hu, Synlett 1993, 5, 337-338.

[178] A.S. EIAzab, T. Taniguchi, K. Ogasawara, Org. Lett. 2000, 2, 2757-2759.

[179] T. Itoh, H. Ishikawa, Y. Hayashi, Org. Lett. 2009, 11, 3854-3857.

[180] A. Huang, J.J. Kodanko, L.E. Overman, J. Am. Chem. Soc. 2004, 126, 14043-14053.

[181] A. Ashimori, T. Matsuura, L.E. Overman, D.J. Poon, J. Org. Chem. 1993, 58, 6949-6951.

[182] A. Ashimori, B. Bachand, M.A. Calter, S.P. Govek, L.E. Overman, D.J. Poon, J. Am. Chem. Soc. 1998, 120, 6488-6499.

[183] T. Matsuura, L.E. Overman, D.J. Poon, J. Am. Chem. Soc. 1998, 120, 6500-6503.

[184] A.B. Dounay, K. Hatanaka, J.J. Kodanko, M. Oestreich, L.E. Overman, L.A. Pfeifer, M.M. Weiss, J. Am. Chem. Soc. 2003, 125, 6261-6271.

[185] M.S. Morales-Ríos, E. Rivera-Becerril, P. Joseph-Nathan, Tetrahedron: Asymmetry 2005, 16, 2493-2499.

[186] B.M. Trost, Y. Zhang, J. Am. Chem. Soc. 2006, 128, 4590-4591.

[187] T. Hirano, K. Iwakiri, H. Miyamoto, A. Nakazaki, S. Kobayashi, Heterocycles 2009, 79, 805-820

[188] T. Kawasaki, M. Shinada, D. Kamimura, M. Ohzono, A. Ogawa, Chem. Commun. 2006, 420-422.

[189] J.P. Marino, M.W. Kim, R. Lawrence, J. Org. Chem. 1989, 54, 1782-1784.

[190] J.P. Marino, S. Bogdan, K. Kimura, J. Am. Chem. Soc. 1992, 114, 5566-5572.

[191] A. Padwa, S. Nara, Q. Wang, J. Org. Chem. 2005, 70, 8538-8549.

[192] P.F. Santos, A.M. Lobo, S. Prabhakar, Tetrahedron Lett. 1995, 36, 8099-8100.

[193] P.F. Santos, N. Srinivasan, P.S. Almeida, A.M. Lobo, S. Prabhakar, Tetrahedron 2005, 61, 9147-9156.

[194] T. Kawasaki, A. Ogawa, Y. Takashima, M. Sakamoto, Tetrahedron Lett. 2003, 44, 1591-1593.

[195] T. Kawasaki, A. Ogawa, R. Terashima, T. Saheki, N. Ban, H. Sekiguchi, K.-e. Sakaguchi, M. Sakamoto, J. Org. Chem. 2005, 70, 2957-2966.

[196] T. Kawasaki, M. Shinada, M. Ohzono, A. Ogawa, R. Terashima, M. Sakamoto, J. Org. Chem. 2008, 73, 5959-5964.

[197] M. Somei, F. Yamada, T. Izumi, M. Nakajou, Heterocycles 1997, 45, 2327-2330.

[198] Y. Fukui, M. Somei, Heterocycles 2001, 55, 2055-2057.

[199] T. Iwaki, F. Yamada, S. Funaki, M. Somei, Heterocycles 2005, 65, 1811-1815.

[200] T. Lindel, L. Brauchle, G. Golz, P. Bohrer, Org. Lett. 2007, 9, 283-286.

[201] S. Takano, M. Moriya, K. Ogasawara, J. Org. Chem. 1991, 56, 5982-5984.

[202] S. Takano, T. Sato, K. Inomata, K. Ogasawara, Heterocycles 1990, 31, 411-414

[203] P.D. Rege, F. Johnson, J. Org. Chem. 2003, 68, 6133-6139.

[204] B.W. Boal, A.W. Schammel, N.K. Garg, Org. Lett. 2009, 11, 3458-3461.

[205] S. Takano, M. Moriya, Y. Iwabuchi, K. Ogasawara, Chem. Lett. 1990, 19, 109-112.

[206] R. Tsuji, M. Nakagawa, A. Nishida, Heterocycles 2002, 58, 587-593.

[207] A. Nishida, S. Ushigome, A. Sugimoto, S. Arai, Heterocycles 2005, 66, 181-185.

[208] M.G. Kulkarni, A.P. Dhondge, A.S. Borhade, D.D. Gaikwad, S.W. Chavhan, Y.B. Shaikh, V.B. Ningdale, M.P. Desai, D.R Birhade, M.P. Shinde, Tetrahedron Lett. 2009, 50, 2411-2413.

[209] C. Mukai, T. Yoshida, M. Sorimachi, A. Odani, Org. Lett. 2006, 8, 83-86.

[210] D. Aburano, T. Yoshida, N. Miyakoshi, C. Mukai, J. Org. Chem. 2007, 72, 6878-6884.

[211] Q.-S. Yu, A. Brossi, Heterocycles 1988, 27, 745-750.

[212] Y. Matsuda, M. Kitajima, H. Takayama, Org. Lett. 2008, 10, 125-128.

[213] V.R. Espejo, J.D. Rainier, J. Am. Chem. Soc. 2008, 130, 12894-12895.

[214] T. Newhouse, P.S. Baran, J. Am. Chem. Soc. 2008, 130, 10886-10887. 
[215] R.C. Larock, E.K. Yum, J. Am. Chem. Soc. 1991, 113, 6689-6690.

[216] T. Newhouse, C.A. Lewis, P.S. Baran, J. Am. Chem. Soc. 2009, 131, 6360-6361.

Create PDF files without this message by purchasing novaPDF printer (http://www.novapdf.com) 